\title{
El Salvador: Financial System Stability Assessment
}

This paper on El Salvador was prepared by a staff team of the International Monetary Fund. It is based on the information available at the time it was completed in May 2010.

Copies of this report are available to the public from:

International Monetary Fund • Publication Services $70019^{\text {th }}$ Street, N.W. • Washington, D.C. 20431

Telephone: (202) 623-7430 • Telefax: (202) 623-7201

E-mail: publications@imf.org Internet: http://www.imf.org

\section{International Monetary Fund Washington, D.C.}




\title{
INTERNATIONAL MONETARY FUND
}

\author{
EL SALVADOR
}

\section{FinANCIAL SySTEM StabiLITY ASSESSMENT}

\author{
Prepared by the Monetary and Capital Markets and WHD Departments
}

Approved by Mr. Viñals and Mr. Eyzaguirre

August 30, 2010

This Financial Sector Stability Assessment (FSSA) is based on the work of a joint IMF-World Bank Financial Sector Assessment Program (FSAP) Update mission to San Salvador from April 27-May 10, 2010.

The main findings are:

- The financial system was resilient in the face of the global shocks and political uncertainty that took a toll on the economy in 2009. The new stand-by arrangement (SBA) with the IMF bolstered confidence in the new authority's policies and also eased concerns over the limited lender of last resort capacity of the central bank.

- Despite the adverse economic environment of 2009, banks' capitalization and liquidity remain high and stress tests indicate most banks could withstand severe shocks. Regulated non-banks are also sound, but pension funds' poor profitability could pose a problem in the longer-term.

- Implementation of the 2004 FSAP update recommendations has been limited, largely because key laws and regulations have yet to be approved. However, the supervisory framework for banks, insurance, and cross-border cooperation were improved, and partial progress was made in strengthening financial infrastructure, the microfinance regulatory framework, and restructuring of state-owned banks.

- $\quad$ Going forward, strengthening supervisory powers and risk assessments, closing regulatory gaps, and enhancing the safety net are priorities to promote financial stability. Passage of the proposed financial system supervision and regulation law would merge supervisory agencies and strengthen supervisory powers, but requires careful implementation and cooperation on regulation, and should also be accompanied by comprehensive crisis management policies and arrangements.

The Update team comprised Eva Gutierrez (Mission Chief, WB); Pamela Madrid (Mission Chief, IMF); Jordi Prat, Andrew Swiston, and Torsten Wezel (all IMF); Patricia Caraballo, Carlo Corazza, Barbara Cunha, Miquel Dijkman, Rekha Reddy, Monica Rivero, Eduardo Urdapilleta, and Clemente Luis del Valle (all WB); Javier Bolzico, Socorro Heysen, and Jose Rutman (all IMF Consultants ); and Hugo Secondini (WB Consultant) .

The main author of this report is Pamela Madrid with input from other members of the FSAP team.

FSAP assessments are designed to assess the stability of the financial system as a whole and not that of individual institutions. They have been developed to help countries identify and remedy weaknesses in their financial sector structure, thereby enhancing their resilience to macroeconomic shocks and cross-border contagion. FSAP assessments do not cover risks that are specific to individual institutions such as asset quality, operational or legal risks, or fraud. 


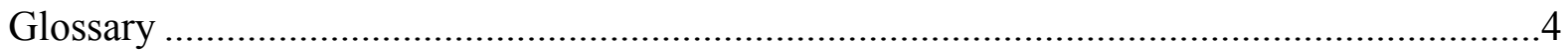

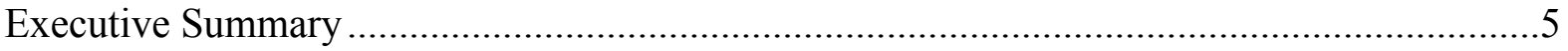

Main Recommendations of the 2010 FSAP Update ...........................................................

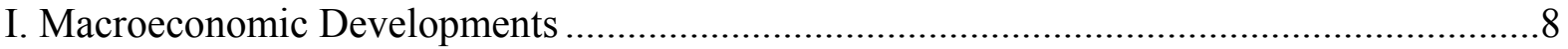

II. Financial Sector Structure and Developments .................................................................

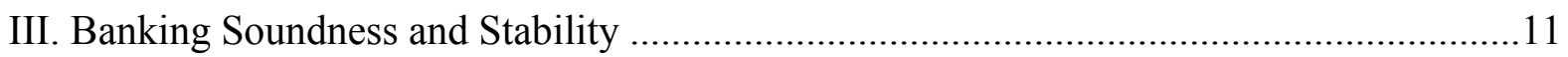

A. Financial Soundness Indicators and Risk Exposures ............................................11

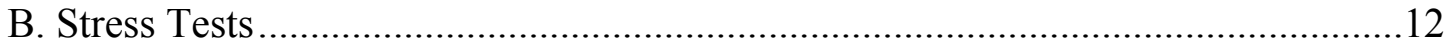

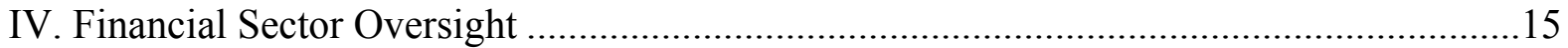

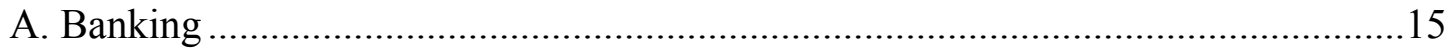

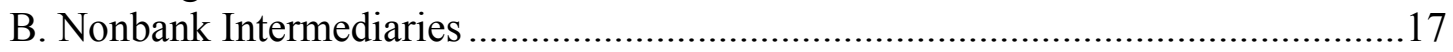

C. Cross-Sectoral and Cross-Border Issues ……………..........................................17

D. Overhaul of the Supervisory Landscape .............................................................19

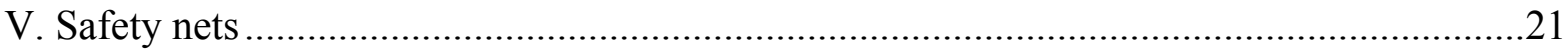

A. Systemic Liquidity and Emergency Liquidity Assistance ......................................21

B. Problem Bank Resolution and Deposit Insurance...............................................23

C. Financial Stability and Crisis Management Arrangements.....................................25

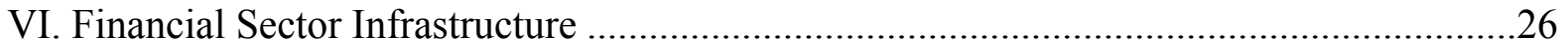

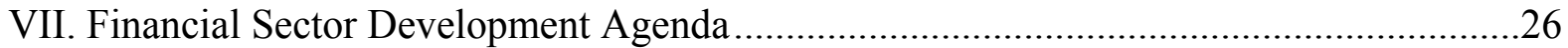

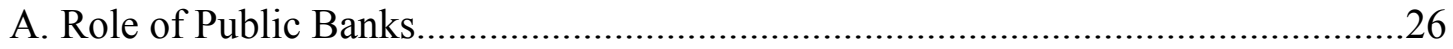

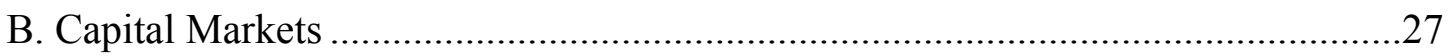

Tables

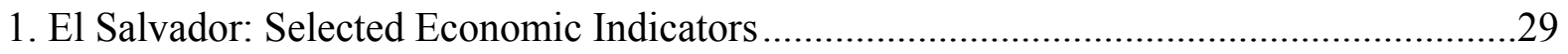

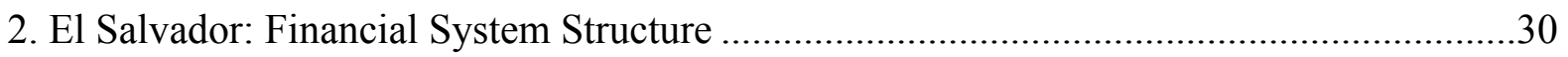

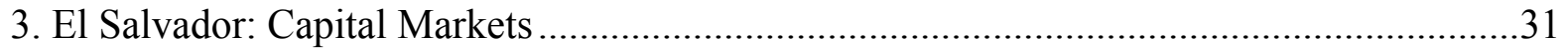

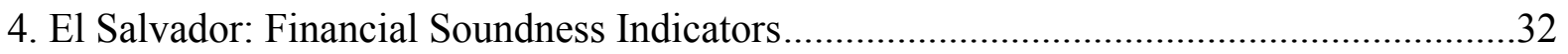

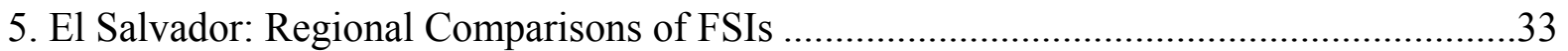

6. El Salvador: Commercial Banking System Liquidity as of Feb 2010 .................................34

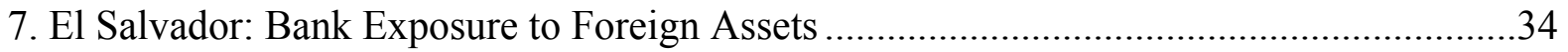

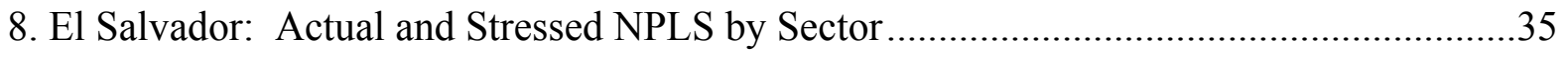

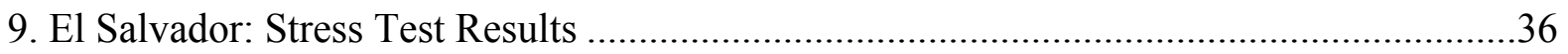

Figures

1.El Salvador: Economic Integration with United States ........................................................

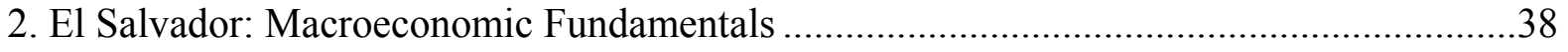

3. El Salvador: Recent Macroeconomic Developments ...........................................................39 
4. El Salvador: Evolution of the Financial System .................................................................40

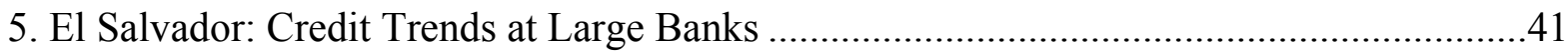

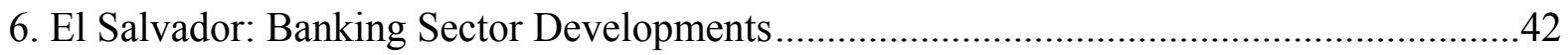

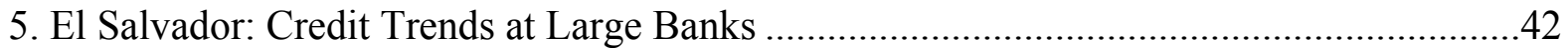

7. El Salvador: Non-Financial Corporate Sector Soundness and Financing ............................43

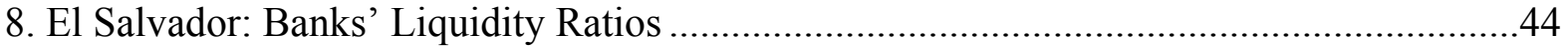

9. El Salvador: Deposit Withdrawals during Electoral Period ................................................4

10. El Salvador: Liquidity in Dollarized Economies ............................................................45

Appendices

I. El Salvador: Implementation of the 2004 FSAP Recommendations ...................................47

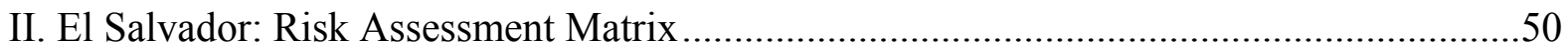

Annex

I. Observance of Financial Sector Standards and Codes - Summary Assessment ..................53

Annex Table

1. Recommended Action Plan to Improve Compliance with the Basel Core Principles .........62 


\section{GLOSSARY}

$\begin{array}{ll}\text { AML/CFT } & \text { Anti-Money Laundering/Combating the Financing of Terrorism } \\ \text { BCR } & \text { Central Bank of El Salvador (Banco Central de la Reserva) } \\ \text { BFA } & \text { Banco de Fomento Agrario } \\ \text { BL } & \text { Banking Law } \\ \text { BMI } & \text { Banco Multisectorial de Inversiones } \\ \text { BH } & \text { Banco Hipotecario } \\ \text { CAR } & \text { Capital Adequacy Ratio } \\ \text { CEDEVAL } & \text { Central Securities Depository } \\ \text { CNR } & \text { National Registry (Central Nacional de Registros) } \\ \text { CPSS } & \text { Committee on Payment and Settlement Systems } \\ \text { FINRA } & \text { Financial Industry Regulatory Agency } \\ \text { FSAP } & \text { Financial Sector Assessment Program } \\ \text { FSSRL } & \text { Financial System Supervision and Regulation Law } \\ \text { GDP } & \text { Gross Domestic Product } \\ \text { IDB } & \text { Inter-American Development Bank } \\ \text { IGD } & \text { Deposit Insurance Fund (Instituto de Garantía de Depósitos) } \\ \text { IFRS } & \text { International Financial Reporting Standards } \\ \text { IMF } & \text { International Monetary Fund } \\ \text { IOSCO } & \text { International Organization of Securities Commissions } \\ \text { LOLR } & \text { Lender-of-Last-Resort } \\ \text { NPL } & \text { Non-Performing Loan } \\ \text { MIL } & \text { Monetary Integration Law } \\ \text { OTC } & \text { Over-the-Counter } \\ \text { P\&A } & \text { Purchase and Assumption } \\ \text { ROA } & \text { Return on Assets } \\ \text { ROE } & \text { Return on Equity } \\ \text { ROSC } & \text { Report on Standards and Codes } \\ \text { RTGS } & \text { Real Time Gross Settlement } \\ \text { SDR } & \text { Special Drawing Rights } \\ \text { SSF } & \text { Financial System Superintendence (Superintendencia del Sistema Financiero) } \\ \text { SV } & \text { Securities Superintendence (Superintendencia de Valores) } \\ & \end{array}$




\section{EXECUTIVE SUMMARY}

Despite the global and domestic shocks of 2008-2009, the banking sector remains sound. Salvadoran banks were not directly exposed to the global financial crisis. However, the parent banks of several major Salvadoran banks were hit hard and directed subsidiaries to conserve risk capital. The higher risk aversion and recession in the United States, combined with uncertainty about the 2009 elections, led to a sharp economic downturn, and a decline in both credit demand and supply. Banks nonperforming loans increased and profitability declined. Even so, capitalization remained high. Stress tests indicate most banks are resilient to a severe macroeconomic, sectoral and liquidity shocks.

Implementation of the 2004 FSAP update recommendations has been limited (Appendix 1). The supervisory frameworks for banks, insurance, and cross-border cooperation were improved and partial progress was made in strengthening the financial infrastructure, insolvency process, microfinance regulatory framework, and restructuring of state-owned banks. However, important legal provisions to strengthen supervision and safety nets, as well as a corporate insolvency law have not yet been approved. Furthermore, while loan classification and provisioning rules were upgraded, important risk and corporate governance regulations for banks have yet to be issued.

The proposed Financial System Supervision and Regulation Law (FSSRL) could improve consolidated supervision and reduce the scope for regulatory arbitrage, but will require careful implementation. The FSSRL would merge the supervisors of banks and insurance, pensions, and securities to create one unified supervisor, with stronger powers. To balance this, the FSSRL would shift regulatory power to the central bank. A sole supervisor and a sole regulator are expected to facilitate consolidated supervision, as well as reduce regulatory gaps and the scope for regulatory arbitrage. However, the merger of supervisors and the institutional split between regulatory and supervisory powers will require a great deal of planning and ongoing cooperation between the supervisor and the regulator to ensure effective supervision.

Remaining gaps in banking supervision and the safety net should be addressed. Supervisory practices should include more qualitative judgment and forward-looking risk assessments, and the regulatory perimeter should be reviewed. Key banking regulation (e.g., on corporate governance as well as credit, market, interest and liquidity risks) must be issued and the proposed FSSRL should more comprehensively address shortcomings in legal protection and the remedial action framework. The banking law should also be amended to strengthen the least-cost bank resolution framework as well as the deposit insurance fund. Regulations implementing the central bank's (limited) powers for emergency liquidity assistance (ELA), as well as the bank resolution process are also needed. Passage of the proposed FSSRL would provide the BCR with more ELA powers, although the authorities should also design and test comprehensive policies for systemic liquidity and banking crisis resolution.

Oversight of financial services provided by entities not subject to prudential regulation should be strengthened, as should the availability of information on borrowers. A range of bank and non-bank institutions provide credit and deposit services to individuals and micro-, 
small- and medium-enterprises. However, below a certain size threshold some are not subject to regulation and supervision by the SSF. Institutions that license and provide voluntary oversight of these institutions should report to the SSF when thresholds are exceeded. A system of auxiliary supervision could also strengthen oversight of these unregulated institutions. To address concerns of over-indebtedness and promote transparency, consumer protection regulations could require lenders to provide borrowers with information on the total cost of a loan. The Banking Law (BL) should be reformed in order to allow the free circulation of credit information among all the members of credit bureaus.

Control over the national payments system should be strengthened, and integration with a regional payment and securities settlement system enacted. The launch of the Real Time Gross Settlement System (RTGS) has substantially improved the safety of large-value payments. However, reforms are needed to ensure the BCR has control over operational reserves and adequate oversight of the system. The Central Bank Law should be amended to implement the regional treaty on payment and securities settlement systems.

Public banks may play an increasingly important role in diversifying and expanding sources of funding for small businesses and infrastructure, but this should be accompanied by enhanced oversight. In the wake of declining credit to the productive sector and the current credit crunch, the Salvadoran authorities have announced an expansion in public banks' activities and are formulating a strategic plan for the sector. So as to not distort the market and maintain their soundness, public banks' activities should be appropriately focused and priced, and government oversight and prudential supervision of these enhanced to ensure adequate governance, systems and controls, and risk management.

Sound capital markets development could bolster the economy's resilience to shocks by diversifying and expanding the sources of funding for corporations, but requires comprehensive reforms. As a result of reform paralysis over the last decade, El Salvador has relatively low standards for securities supervision, and market development has been constrained. The passage of a new Investment Funds Law and comprehensive reform of capital markets legislation would help expand the investor base and facilitate regional integration. This financial deepening may allow for increased private investment and growth, which could bolster the economies resilience to shocks. 
MAIN RECOMMENDATIONS OF THE 2010 FSAP UPDATE

\begin{tabular}{|c|c|}
\hline Main Recommendations Requiring Legal Reform ${ }^{1} /$ & $\begin{array}{l}\text { Time } \\
\text { Frame }\end{array}$ \\
\hline \multicolumn{2}{|l|}{ Banking Oversight } \\
\hline $\begin{array}{l}\text { Approve the proposed FSSRL, amending the draft to include adequate legal protection for supervisors, } \\
\text { and broader preventive powers prior to regularization. }\end{array}$ & NT \\
\hline \multicolumn{2}{|l|}{ Safety Nets } \\
\hline Allow the BCR to lend to banks with its own or external funds in case of emergency. & NT \\
\hline $\begin{array}{l}\text { Eliminate } 3 \text { day notification period for resolution measures; require removal of a bank's board at judicial } \\
\text { intervention; limit IGD to the least-cost solution; and increase IGD's funding options and target fund. }\end{array}$ & NT \\
\hline \multicolumn{2}{|l|}{ Capital markets } \\
\hline Approve the proposed Investment Funds Law. & NT \\
\hline Approve a comprehensive overhaul of the securities markets law. & MT \\
\hline Amend the Pension Funds Law to increase the number and type of investments allowed. & MT \\
\hline \multicolumn{2}{|l|}{ Access to Finance } \\
\hline Require federations to collect and report information to the SSF. & NT \\
\hline Allow for the transfer of an invoice to a third party. & MT \\
\hline \multicolumn{2}{|l|}{ Financial Infrastructure } \\
\hline Allow the free circulation of credit information among all members of private bureaus. & MT \\
\hline \multicolumn{2}{|l|}{ Main Recommendations Not Requiring Legal Reforms ${ }^{1 /}$} \\
\hline \multicolumn{2}{|l|}{ Banking Supervision } \\
\hline Issue regulations for key risks and corporate governance. & NT \\
\hline $\begin{array}{l}\text { Bring qualitative assessments in line with international best practices and appoint dedicated } \\
\text { relationship manager responsible for the overall supervision of each bank. }\end{array}$ & NT \\
\hline Intensify supervision of credit concentration and debtor repayment capacity. & NT \\
\hline \multicolumn{2}{|l|}{ Safety Nets } \\
\hline Implement a comprehensive liquidity policy, which includes objectives and contingency plans. & NT \\
\hline Issue regulations to implement its powers to provide liquidity. & NT \\
\hline MOF allocates the entire SDR allocation granted in 2009 to the BCR for ELA. & NT \\
\hline SSF, BCR, and IGD formalize procedures and manuals for banking resolution and crisis management. & NT \\
\hline SSF, BCR, IGD and MOF undertake a comprehensive bank resolution simulation exercise. & NT \\
\hline \multicolumn{2}{|l|}{ Capital Markets } \\
\hline Rationalize the securities exchange's role in the market. & MT \\
\hline Adopt an external yield curve (US yield curve) for valuation of portfolios. & NT \\
\hline Implement the action plan to comply with IOSCO principles. & NT \\
\hline \multicolumn{2}{|l|}{ Access to Finance } \\
\hline Harmonize requirements for credit and registration of assets in exempting low-value transactions. & MT \\
\hline \multicolumn{2}{|l|}{ Public Banks } \\
\hline MOF creates coordination mechanisms among the three public banks. & NT \\
\hline SSF implements schedule of on-site visits and off site reviews of public banks' financial information. & NT \\
\hline Public banks improve credit risk analysis and operative processes. & NT \\
\hline Consolidate and redefine the guarantee funds and scale up the mutual guarantee scheme (SGR). & NT \\
\hline \multicolumn{2}{|l|}{ Financial Infrastructure } \\
\hline BCR implements its oversight functions of the payment systems. & NT \\
\hline BCR introduces a liquidity scheme for the RTGS. & NT \\
\hline BCR creates an alternate site for the RTGS. & NT \\
\hline Implement linkage between RTGS system and CEDEVAL. & NT \\
\hline
\end{tabular}

$1 /$ FSAP recommendations that do not directly impact near-term stability are not discussed in the FSSA.

2/ Near-Term (NT) is one to three years and medium-term (MT) is three to five years. This is the period during which it is would be feasible to complete implementation of the high-priority recommendations. 


\section{MaCroeconomic DeVelopments}

1. Between the 2004 FSAP Update and the global financial crisis of 2008, economic growth accelerated and financial integration with the United States increased. The Salvadoran economy is highly linked with that of the United States (Figure 1). Since 2004, a favorable external environment, growing trade with the United States, and rising remittances helped real GDP grow by an average of $3 \frac{1}{2}$ percent from 2005-2008, compared to 2 percent from 2001-2004 (Table 1). Nonetheless, growth remained below the regional average, weighed down by low private investment and saving (Figure 2).

2. In 2008-2009, the economy was hit by a number of shocks, tipping the economy into a recession from which it started to recover in $\mathbf{2 0 1 0}$. With the intensification of the global financial crisis in late-2008 and uncertainty about economic policies in advance of the 2009 elections, the sovereign spread rose sharply and banks' liquid assets and lending interest rates increased, while credit and deposit growth decelerated sharply. ${ }^{1}$ The deterioration in global growth - especially in the United States - and increased uncertainty about economic prospects sharply reduced trade, remittances, and private capital flows in 2009 (Figure 3). Despite the partial use a \$400 million Inter-American Development Bank (IDB) line-through which the central bank purchased high-quality loans from commercial banks - as well as reduction in the liquid asset requirement, credit to the private sector declined $4 \frac{1}{2}$ percent. Investment and private consumption fell sharply, and real GDP declined by $31 / 2$ percent. The recession pushed the fiscal deficit to $5 \frac{1}{2}$ percent of GDP and public sector debt rose to 50 percent of GDP, leading credit rating agencies to downgrade the sovereign by one notch. ${ }^{2}$ For 2010 , economic growth is envisaged at 1 percent, aided by a robust recovery in exports and modest recovery in remittances.

3. The authorities' policy priorities are to increase key social spending and spur credit and private investment within a framework that safeguards debt sustainability. A new stand-by arrangement (SBA) with the IMF approved in March 2010 aims to signal a continued commitment to macroeconomic stability and official dollarization. ${ }^{3}$ The authorities envisage a fiscal pact containing tax measures of at least $1 \frac{1}{2}$ percent of GDP to support key social program spending as well as durable fiscal consolidation. Furthermore, the authorities have developed a strategic plan to increase credit and investment, including by strengthening two small public commercial banks and through a new government credit guarantee fund and economic development fund, both administered by a newly structured public development bank. Approval of laws to reform financial sector supervision and regulation, and to provide a framework for investment funds are key parts of the strategy (as well as benchmarks for financial sector structural reforms under the SBA).

\footnotetext{
${ }^{1}$ Part of the increase in banks liquid assets was due to an increase in the required liquid reserve holdings put in place prior to the election.

${ }^{2}$ Fitch and S\&P rate El Salvador BB, while Moody's rating is Ba1. Fitch and Moody's have a negative outlook on the sovereign rating.

${ }^{3}$ El Salvador officially adopted the U.S. dollar as its currency in 2001.
} 
4. Downside risks to the baseline growth forecast and near-term macroeconomic stability arise mainly from exposures to political and external shocks. Growth is expected to remain below potential through 2012, as the fiscal stimulus is withdrawn and credit recovers slowly, but pick-up to 4 percent thereafter. However, a double-dip recession in the United States could lead to an economic downturn that endangers the fiscal targets. Furthermore, fiscal sustainability hinges on timely congressional approval of financing and on broad-based political support for further fiscal consolidation. Deterioration in either external market conditions or political support could raise financing risks - including from the need to roll over a Eurobond in 2011 - as well as liquidity risk. These and other events that would have a significant negative impact on the macroeconomic environment and could impact financial stability are discussed further in the Risk Assessment Matrix (Appendix 2).

5. There are longer-term risks arising from pension-related contingent liabilities. Funding requirements for pensioners on the old pay-as-you-go system are in the order of $1 \frac{1}{2}$ percent of GDP. Lower-than-expected returns under the new defined contribution system may create a wedge between returns earned and the minimum pension that the current system grants, which creates a potential contingent liability for the government.

\section{FinAnCial SECTOR StruCtURe AND DeVElopMents}

\section{El Salvador's bank-centered financial sector is growing more slowly than the} regional average. The Salvadoran financial sector is dominated by banks (Table 2). Since the banking crisis of the late 1990s, credit-to-GDP has stagnated. Some financial intermediation is taking place through many small and unregulated entities, which are not captured in official statistics. Nonetheless, with US\$8 billion in bank credit outstanding and credit-to-GDP at 40 percent of GDP, El Salvador is now lagging behind the regional average (Figure 4).

7. Capital markets in EI Salvador remain small and relatively underdeveloped. At end 2009, there were only 40 listed stocks and a few private corporate bond issuers (Table 3). Stock market capitalization of US\$5.2 billion (24.6 percent of GDP) was slightly above the regional average (Figure 4). However, excluding the shares of the financial institutions that are largely controlled by foreign institutions and hardly traded, remaining capitalization was only US $\$ 1.2$ billion (5.6 percent of GDP). About US\$6 billion (28.7 percent of GDP) in government securities are outstanding, but 67 percent of this is represented by Eurobonds issued in the international market. Private debt securities outstanding equal only 3 percent of GDP, below the regional average. Overall, institutional investors (mainly banks and pension funds) invest less than 10 percent of their total assets in capital market instruments.

8. The ownership of the financial sector has changed dramatically in recent years and is now almost fully foreign-owned. Foreign ownership expanded with the purchase of or merger with the four largest banks by regional and international financial groups between 2005 and 2007. Currently, El Salvador has the largest presence of foreign banks among Central American countries, with two domestic banks (both state-owned) accounting for only 5 percent of banking assets. As before, financial groups (i.e., those including a combination of banks, 
insurance, and securities companies), remain an important feature of the financial sector, but now have an increasingly international and regional dimension.

9. Foreign-owned banks have restructured their credit portfolios and several have reduced credit to firms, as in other parts of the region. Most larger private banks expanded credit during the economic upswing that began in 2004 and prior to their sale to international banks. Following the change in ownership, the foreign-owned banks increased write-offs and rationalized credit lines according to the stricter policies of their parents. The global financial crisis and ensuing economic downturn led to a continued downward trend in credit at some of foreign banks, although one internationally owned bank increased credit sharply as did public banks (Figure 5). As in other parts of the region, consumer credit has grown faster than corporate credit, which has actually declined in real terms.

10. Increased consumer credit has been accompanied by concerns of over-indebtedness, prompting legislation on loan workouts and stronger consumer protection provisions. Between 2004 and 2009, the number of loans to individuals increased 33 percent. Lack of complete credit history information available to non-regulated financial institutions, which service mostly the lower end of the market, may be exacerbating the problem among small debtors. Some lenders have exited the under US\$1,000 market, which they view as increasingly risky. A recently proposed law would require increased transparency about costs and any lack of clarify in a loan contract should be interpreted in favor of the client. A special loan work out unit would be created in the Salvadoran consumer defense agency to assist borrowers in loan restructurings. This may increase banks legal risks.

\section{Brokerage houses owned by foreign banks have eliminated their fund management} activities, reducing their exposure to liquidity and legal risks. There is no mutual fund industry in El Salvador due to the lack of a proper regulatory framework, but brokers had traditionally provided fund management services. However, these broker funds have been effectively phased-out following the purchase of the domestic financial groups by international and regional banks. The risks created by inadequate regulation - which do not require mark-tomarket valuations, nor clear separation of the fund's assets - as well as the marketing of these funds as though they were sight bank deposits, redeemable on demand at face value, were deemed too high. As a result, investment funds' assets decreased from US\$700 million in 2006 to only US\$79 million in 2010, with only one, independently-owned, fund remaining.

12. In contrast, pension funds have accumulated a greater share of total financial assets, although these are mainly invested in government securities. Pension funds, originally set up in 1998, have expanded rapidly due to mandatory contributions and as younger workers joined the new capitalization system. Assets under management (US\$5.3 billion at end-March 2010), account for 24 percent of financial sector assets. These are invested in fixed-return investments, mostly public sector securities (79.4 percent). 


\section{BANKING SOUNDNESS AND STABILITY}

\section{A. Financial Soundness Indicators and Risk Exposures}

13. Since the 2004 FSAP Update, banks' capitalization has strengthened, while asset quality improved through 2007 due to the cyclical upturn and write-offs. The minimum required capital adequacy ratio (CAR) was increased to 12 percent in 2005 and most banks currently maintain significant additional capital buffers (Table 4). The largest (foreign-owned) banks introduced more stringent corporate credit underwriting in line with their parent company policies. Nonperforming loans (NPLs) remained relatively low (around 2 percent of total loans) between 2005 and 2007, helped by the cyclical upswing. Furthermore, banks wrote-off about 2 percent of total loans during 2006-2007.

\section{While banks were not directly exposed to toxic assets or heavily dependent on} wholesale funding, the global financial crisis along with the start of the electoral period led to shedding of riskier assets. Some Salvadoran subsidiaries of international banks were restricted by their headquarters in the use of risk capital and faced reductions in external credit lines, despite these subsidiaries being well-capitalized. Fortunately, confidence in these subsidiaries was bolstered by the support that was provided to the parent financial group by their home governments. However, coupled with uncertainty regarding economic policies prior to the elections in mid-2009, annual deposit growth was briefly negative in January 2009. Amid this increased and widespread risk aversion, external borrowing declined close to 50 percent, and liquid assets increased to over 40 percent of deposits (Figure 6).

\section{With the ensuing credit crunch and recession of 2009, asset quality and profitability} deteriorated. NPLs rose by less than 1 percentage point to $3 \frac{3}{4}$, but in line with the stronger downturn in El Salvador the ratio rose by more than in the rest of Central America (Table 5). ${ }^{4} \mathrm{~A}$ wider measure of loans at risk, incorporating restructured and refinanced loans suggests a stronger deterioration in asset quality to 10 percent of total loans. Furthermore, write-offs amounted to $2 \frac{1}{2}$ percent of the loan portfolio in 2009. The additional provisions — offset to some extent by higher interest rate margins - weighed on already low bank profitability, with the return on average assets falling to 0.3 percent in 2009, well below the rest of the region.

16. Despite this deterioration, most banks remain highly capitalized. Although a few banks are close to the regulatory minimum, the system's capital adequacy ratio of 16.5 percent is relatively high. This high level of capitalization reflects an increase in liquid assets, which carry a low risk-weight, as well as capital injections in some banks. The quality of capital is also high (Tier 1 capital amounts to 13.7 percent of risk-weighted assets and consists mostly of retained earnings), and the leverage ratio is low (Tier 1 capital is 8.9 percent of on- and off-balance sheet assets). Regulatory capital (Basel definition) is slightly overstated at a number of banks due to the inclusion of goodwill resulting from the acquisition of banks and other intangible assets, but the amounts are not material (only about 1 percentage point of capital). Similarly, adjusting

\footnotetext{
${ }^{4}$ FSIs are not fully comparable across countries given differences in regulations and supervision.
} 
provisions to a debtor's lowest risk classification slightly affected the CARs of only a couple of small banks, with almost no impact for the total system. Adjusting for possible underprovisioning of restructured agricultural loans held off-balance sheet in a trust (Ficafe), would not result in any bank being undercapitalized, with the system CAR declining to 15.4 percent. ${ }^{5}$ Furthermore, adjusting for government bonds' risk weight (from zero to 100 percent) reduces the system CAR to 14.7 percent, and most banks still have a comfortable buffer of at least 1 percentage point above the minimum 12 percent.

\section{Banks' direct cross-border exposures are limited by bank policies and regulation,} and ownership linkages appear to have only had marginal impacts on these. Cross-border lending accounts for only about 4 percent of total loans and less than 20 percent of capital (Tables 5 and 7). Banks' deposits and investments held abroad are mostly low-risk investments held to comply with reserve requirements. Equivalent to 54 percent of capital, these are not a large exposure for banks; and at 7 percent of liabilities, these are equal to banks' external borrowing. This reflects parent banks' policies that require their subsidiaries to mostly fund and lend domestically. Regulatory requirements also contain cross-border risks. ${ }^{6}$ In total, as of March 2010, exposure to foreign assets was equal to less than 80 percent of capital, and the direct exposure to parents was only about 12 percent of capital (up from 6 percent in March 2009). Reputational risk from identification with the parent financial group currently has been limited, as international banks have had sovereign support. While, foreign-owned banks may be required by their headquarters to respond if the group is under stress (e.g., by saving on risk capital, repatriating dividends, and even providing liquidity or lending to the parents), this appears to have been limited (and are well within prudential limits).

\section{B. Stress Tests}

\section{Three macroeconomic scenarios were developed to gauge the sensitivity of banks' loan portfolio to various macro and sectoral shocks. ${ }^{7}$}

- $\quad$ The baseline scenario is the current IMF forecast of 1 percent real GDP growth in 2010 and 2.5 percent in 2010 (see Article IV staff report). This is predicated on a solid recovery in U.S. growth of 3.1 percent in 2010 and 2.4 percent in 2011.

- $\quad$ The downside scenario assumes slightly negative growth in the United States and real GDP growth of only 0.1 percent in 2010 and 0.4 percent in 2011 in El Salvador. ${ }^{8}$

\footnotetext{
${ }^{5}$ This is in the worst case that banks have not provisioned for these loans according to their risk-classification.

${ }^{6}$ There is an individual limit of 10 percent of capital and overall limit of 150 percent of capital for the total of foreign asset exposure. Deposits and investments rated AA or higher included in the liquidity reserve requirement are excluded from these limits.

${ }^{7}$ Aggregate employment, exports, remittances, and sectoral output and employment are projected based on historical elasticities to aggregate output.

${ }^{8}$ This relationship is based on an estimated vector-autoregression between growth in El Salvador and the United States.
} 
- $\quad$ The extreme scenario assumes Salvadoran real GDP declines significantly by 5.4 percent in 2010 and 2.5 percent in 2011 - an outcome three standard deviations below the norm.

19. In the extreme scenario, close to $\mathbf{5 0}$ percent of total loans could require provisioning be end-2011. Using panel data, the responsiveness of NPLs to shocks was estimated for each of the main sectoral credit classifications, i.e., consumer, mortgage, manufacturing, extraction, construction, retail, transportation, and other services. The definition of NPLs included all impaired loans, ranging from special mention to loss loans, as well as loans written off, in order to take full account of the provisioning requirements from asset deterioration. Based on the estimated model, NPLs depend largely on the trend (lagged levels) in NPLs, as well as lagged output or employment. For loans to the household sector, remittances are also an important variable, while for loans to the productive sectors input prices (e.g., oil or construction prices) also are significant. In the extreme scenario, by end-2011 almost 50 percent of loans become risky loans (i.e., classified special mention or worse) that require provisioning (Table 8). The impact of the extreme shock is most severe for manufacturing, extractive and construction sector loans, where between $60-80$ percent would need to be provisioned.

\section{Nonetheless, most banks' profit and capital buffers are large enough to withstand} the severe deterioration in credit quality under the extreme scenario. In all the macroeconomic scenarios, the system's CAR remains above the regulatory minimum of 12 percent of risk-weighted assets, however, in the extreme scenario five banks fall below the minimum CAR (Table 9). These five banks are those with a higher concentration of loans in riskier segments, notably construction that has experienced a protracted downturn. While two of the five banks would be under 10 percent CAR in the extreme scenario - and thus require a regularization program with the SSF-only in one (nonsystemic) case is this undercapitalization critical. $^{9}$

\section{Banks' capital adequacy is more sensitive to credit concentration risk, but losses are} limited by the loan-to-value limit. Large firms and borrowers were strongly affected by the economic slowdown: profit margins fell, and the average risk classification for the largest debtors increased more than those of smaller corporate debtors (Figure 7). Downgrading the classification of the system's 100 largest debtors by two grades causes the CARs of six banks to fall substantially, although all banks would retain a CAR above 9 percent. In the case of an outright default of the largest ten debtors, up to five banks become undercapitalized, with four banks falling below 10 percent CAR (but with no bank becoming critically undercapitalized). Losses are limited given the maximum value of collateral for provisioning purposes is 70 percent. $^{10}$

\footnotetext{
${ }^{9}$ There is no standard benchmark for undercapitalization, but in the U.S. a bank with a CAR below 2 percent is considered critically undercapitalized.

${ }^{10}$ Collateral (at full value) is taken into account, such that the loss given default is the difference between the loan and permissible collateral values.
} 
22. Declines in the collateral values of large borrowers, however, appear manageable. The value of loan guarantees was reduced by 25 percent to adjust the present value of these for the lengthy liquidation process. ${ }^{11}$ This haircut results in a drop of the system's CAR to 12.8 percent, with four banks falling below the regulatory minimum ratio by between $1 / 2$ and $1 \frac{1}{2}$ percentage points.

23. Banks' interest rate risk also appears manageable. A sensitivity analysis assessing repricing risk assumes an increase in short-term interest rates by $1 \frac{1 / 2}{2}$ and 3 percentage points. In the latter case, three banks drop below the 12 percent minimum required CAR, and the system's CAR declines to only 13.1 percent. However, only 1 non-systemic bank falls slightly below 10 percent CAR. Based on the results of the estimated NPL model, the impact of indirect interest rate risk (i.e., interest rate induced credit risk) would also not be significant.

\section{Most banks could withstand a large liquidity shock without resorting to central} bank liquidity support. The test assessed the coverage provided by banks' liquid assets in the case of a withdrawal of 15 and 30 percent of total deposits within 30 and 90 days, respectively, also assuming a lack of rollover of other liabilities maturing in these periods. The coverage provided by such liquid assets (Figure 8) is sufficient for most banks, even assuming all private domestic securities are illiquid and applying a 25 percent haircut to the face value of eligible government securities. ${ }^{12}$ The overall magnitude of the largest shock assumed is larger than the largest individual withdrawal last experienced in the run-up to the 2004 presidential election (Figure 9). That said, in this scenario a few banks would need to access the third tranche of liquid reserves held at the BCR in the form of securities. Furthermore, the costs of accessing the second and third tranches of liquid reserves would reduce profitability.

\section{The authorities' stress testing capabilities are improving, but some important data} gaps should be addressed and interagency coordination strengthened. The three safety net providers (BCR, SSF, and IGD) have each made laudable progress in analyzing banking risks, including by creating an interagency committee for risk analysis. Even so, the current stress test methodology could be enhanced, and activities better coordinated across the institutions. The risk analysis committee should therefore focus on unifying and upgrading the approach with a view to conducting regular stress tests. To improve the capacity to analyze risks, the remaining gaps in data provision - notably, loan collateral, cash-flows, the remaining maturity structure of liabilities ${ }^{13}$, and interest rates of securities and loans - should be addressed.

\footnotetext{
${ }^{11}$ The 2010 World Bank Doing Business reported that contract enforcement in El Salvador takes 786 days.

12 The BCR can repo government with funds deposited by the state in case of a liquidity crisis. Internal guidelines call for a 25 percent haircut on government securities.

${ }^{13}$ In particular, the SSF should improve liquidity requirements by requiring information on the residual, not the contractual terms of all liabilities. Furthermore, domestic and foreign liabilities should be treated equally.
} 


\section{FinanCial Sector Oversight}

\section{A. Banking ${ }^{14}$}

26. SSF supervision should focus more on assessing the quality of risk management and internal controls. The SSF was reorganized in 2008 in order to implement risk-based supervision. It now has a risk unit so that the supervisory teams may tap specialized expertise in various risk areas, which has helped strengthen supervisory practices. The SSF currently uses CAMELS models in order to establish bank-specific risk profiles. However, more qualitative assessments of risk management are needed. In particular, besides checking whether procedures and policies are in place, the SSF should also assess the quality of risk management and internal controls given the bank's risk characteristics (e.g., size, complexity, and risk tolerance capacity).

\section{The existing regulatory framework has significant gaps, which need to be filled} urgently. Regulation is lacking in such areas as corporate governance, credit risk, liquidity risk, market risk, operational risk, interest rate risk in the banking book, information technology and investment valuation and derivatives. Many of these are under development, but have faced bottlenecks in the approval process, including lengthy industry consultations and SSF's executive council's increasing involvement in operational matters to the detriment of strategic policy decisions. Although supervisory practices in these areas have improved, the lack of standards puts the SSF at a disadvantage in addressing imprudent behavior by banks. This is aggravated by a lack of legal protection for supervisory staff. Legal challenges not only distract supervisory resources from where they are needed most, they may also diminish the willingness of the SSF to use its corrective powers ex-ante in order to avoid dealing with these challenges.

\section{The remedial action framework should allow the SSF to respond proactively to} emerging risks. In particular, the SSF should have powers to require banks to take corrective actions before inadequate practices or vulnerabilities lead to undercapitalization. In particular, the toolkit does not include powers for the supervisor to limit the distribution of dividends, constrain existing or new operations and acquisitions, or enforce the sale of assets.

29. While asset classification and provisioning rules were tightened in 2007, a credit risk regulation covering repayment capacity and concentration risks is still needed. Provisioning levels are now broadly in line with international practices, and the SSF monitors banks' delinquent loan portfolio intensively. However, given the sensitivity of banks' CAR to concentration risk, the SSF should regulate and supervise the sum (aggregate) of individual large exposures, or loans linked by credit risk, more vigorously. Furthermore, the requirement to downgrade corporate loans if the repayment capacity of the debtor so warrants should be extended to consumer and mortgage loans. Also, when debtors with multiple loans with various banks default on one loan, but stay current on others, the classification of the current loans

\footnotetext{
${ }^{14}$ See Annex: ROSC on Basel Core Principles for Effective Banking Supervision.
} 
should be downgraded. Lastly, the practice of granting several mortgages on the basis of one underlying asset should be monitored more closely.

30. The capital adequacy framework should be brought fully in line with international standards. Intangible assets (mostly goodwill), are not subtracted from capital as required under Basel I. While these are currently of limited significance, further consolidation and investments in the system could elevate these amounts. Over the medium-term, the law should be amended to bring capital requirements in line with Basel standards.

31. The regulatory perimeter should be reviewed to ensure adequate oversight of the cooperative sector, and other credit entities not subject to SSF regulation and supervision. Cooperatives that take deposits from the public or for which the sum of member deposits and members contributions to equity exceeds US\$84 million are supervised by the SSF according to the Cooperative Banking Law. The majority of cooperatives, however, are not subject to prudential regulation and supervision, and SSF has no way of determining when unregulated institutions pass the US\$84 million threshold. Several other financial intermediaries such as mortgage companies, factoring companies and consumer durables lenders are also not regulated and supervised. These unregulated and unsupervised entities are not restrained by the definition of permissible activities that apply to regulated entities. The licensing and voluntary oversight entities should strengthened their limited information systems and have the power to penalize institutions that do not report required information. A system of auxiliary supervision through the federations that provide voluntary oversight of their member institutions could enable these entities to perform supervisory tasks - such as data collection, processing and recommendations of procedures — on behalf of SSF. However, this may require significant strengthening of these voluntary oversight entities. To address concerns of over-indebtedness and promote transparency, consumer protection regulations could require lenders to provide borrowers with information on the total cost of a loan.

32. The SSF faces human capacity constraints, due to organizational issues and a lack of resources (both quantitatively and qualitatively). Offsite responsibilities are currently split over two divisions (Risks and Analysis), and the role and responsibilities of offsite supervision are not well-specified. In addition, individual supervisory staff is often given a number of different roles, which is most problematic in the Risk Division. The unit leaders of this Division are responsible not only for monitoring a specific risk across all banks, but are also the designated "relationship managers" for a financial conglomerate. Offsite supervisors should be assigned to specific banks and conglomerates, allowing unit heads to focus on assessing the adequacy of this supervision and putting together a broader assessment of risks in the banking system. To strengthen the supervisory review process it is essential to further upgrade supervisory capacity, both in quantitative and in qualitative terms. Furthermore, the Supervisory Department is resource-constrained, as the increased consumer protection responsibilities entrusted to the SSF have been assigned to this department, diverting supervisory resources away from prudential supervision. Consideration should be given to creating a separate consumer protection department. 


\section{B. Nonbank Intermediaries}

33. Supervision of the insurance sector has improved in the recent years, but a more risk-based approach and more on-site supervision are needed. The SSF developed and launched the CARAMEL system for insurance companies, which is used to identify areas of potential difficulty in the insurance sector. ${ }^{15}$ Going forward, the SSF should continue developing risk-based supervision to move beyond assessment of compliance with existing rules, and increase their on-site visits to individual insurers to complement the current focus on conglomerates.

34. The securities supervisory framework requires a comprehensive reform to comply with the international standards. While securities were not assessed in the 2004 FSAP update, detailed assessments of the regulatory and supervisory framework were conducted by the IOSCO secretariat and by the U.S. self-regulatory organization (FINRA) in 2004 and 2005. These assessments highlighted very low compliance with international standards (IOSCO principles). Priority areas identified for reform included (i) mitigation of investor and systemic risks in brokerage funds, (ii) the need to update the overall regulatory framework (laws and rules), (iii) implementing risk oriented supervision, and (iv) strengthening the supervision of the brokers and market surveillance. While the first item is no longer an issue, the other areas still require significant work and require implementation of an action plan to comply with IOSCO principles that includes a comprehensive reform of the securities market law (see Section VII.B).

\section{Cross-Sectoral and Cross-Border Issues}

35. The SSF has made some progress in consolidated supervision, but additional efforts are needed to better assess the risks presented by non-banking local activities at the group level. The SSF now coordinates with other local supervisors of financial entities, to gather information and to conduct simultaneous onsite exams. However, there remains considerable scope for deepening the analysis and translating the outcomes in terms of potential impacts on capital and liquidity. In addition, the threshold for consolidation used in practice (50 percent of capital), is quite high. ${ }^{16}$

36. The SSF has stepped up its efforts to enhance cross-border cooperation, including on crisis management issues, but these should also involve the other safety net providers. In response to the changing ownership structures in the Salvadoran banking sector, it has signed Memoranda of Understanding with all home supervisors. Discussions with the SSF and with two home supervisors confirmed that these agreements have strengthened the exchange of relevant information: the home supervisors expressed satisfaction with their access to information on

\footnotetext{
${ }^{15}$ The financial indicators used related to solvency, assets and liabilities, profitability, reinsurance and administrative costs, which are weighed to obtain a quantitative rating.

${ }^{16}$ The SSF is empowered to assume the existence of control based on other criteria, but this is not commonly done in practice.
} 
Salvadoran banking operations, and the SSF is satisfied with the information they receive on the overall financial condition of the cross-border conglomerates. These agreements primarily cover exchange of information in the context of ongoing supervision. In addition, the Comite de Enlace of Central American supervisors (CECAS) has stepped up regional coordination. CECAS has quarterly meetings and monthly teleconferences where supervisors present relevant information, risks and concerns about the banks operating under their jurisdictions. Recently, the SSF participated in a regional crisis simulation exercise organized by the World Bank. The BCR and IGD should also be incorporated given they are also involved in banking resolution.

\section{While there is continuous communication with banks' home supervisors, more specific cross-border crisis prevention and management arrangements should be} established. The frequency and channels of communication seems adequate for the assessment of the bank's cross-border risks. However, no crisis MOUs or contingency plans to manage a crisis in coordination with foreign supervisors are in place. Arrangements between home and host supervisors with the aim of avoiding and mitigating the effects of a potential crisis should be established by assessing information needs and establishing appropriate communication strategies.

38. The legislation criminalizing money laundering (ML) and the financing of terrorism (FT) complies with the FATF standard, but preventive measures and the supervisory framework require an overhaul. ${ }^{17}$ The law has allowed the country to prosecute successfully several cases and cooperate with other countries. Nevertheless, the number of convictions is low relative to the number of crimes that generate proceeds, and prosecutions mostly relate to cash smuggling rather than more complex or higher-impact schemes. The effectiveness of seizing and freezing measures is limited, with precautionary asset seizures imposed in less than half of the investigations. Also, some financial activities - particularly money remittance and all designated non-financial businesses and professions - fall outside of any regulatory and the supervisory framework. The Financial Investigations Unit (FIU), established within the Public Prosecutions Agency, is the lead agency in the fight against Ml/FT - it is able to issue enforceable regulations, and responsible for investigating and prosecuting most cases. However, it lacks the necessary expertise, resources and operational autonomy to carry out its functions effectively. Moreover, the concentration of functions (FIU, regulator and lead prosecutor) within the unit seems excessive and inappropriate.

\section{Gaps in the legal and regulatory framework for payment systems should be} addressed promptly. The Central Bank Law should be amended to fully implement the Treaty on the Payment and Securities Settlement Systems for Central America and the Dominican Republic. The amendment, which is already drafted, would provide the BCR with the adequate

\footnotetext{
${ }^{17}$ This assessment was conducted by the Caribbean Action Task Force in 2009, and the Mutual Evaluation Report agreed in June 2010.
} 
powers to regulate fees and sanctions in the payments system. However, the BCR would still need to develop a new regulatory framework for payment services.

40. The BCR should also strengthen its oversight of the national payment systems. Currently, information is provided by the private sector on a voluntary basis. The BCR should define more clearly, possibly through regulation, its powers to collect information from system participants and to adequately oversee the payment systems, particularly at the retail level, by specifying methodologies and requesting periodic reports.

41. The BCR should be able to ensure that it retains control over the operations and oversight of the national payments system. If banks find it more convenient to settle their inter-bank payments abroad in an offshore settlement bank or system, the BCR may not be able to control risks to the payments systems. It could lack access to essential information abroad and, furthermore, the default of an overseas counterparty could lead to logjams in settlements in El Salvador. To avoid this, the BCR should consider providing services that banks value, such as an array of tools to facilitate high quality cash management by the Treasurers of financial institutions, and perhaps an intra-day liquidity facility for the RTGS system (e.g., via a specially designed intra-day repo facility, with operations to be conducted on a regular basis). To ensure control over the payment systems, banks should be required to maintain the first tranche of the reserve at the BCR while part of the last tranche, for exceptional use, could be maintained abroad.

\section{Overhaul of the Supervisory Landscape}

\section{The Salvadoran authorities have proposed an overhaul of the supervisory and} regulatory architecture. A draft law on Financial System Supervision and Regulation (FSSR) is currently with the Congress and it should be passed this year. The law will: (i) merge the superintendencies of banks, insurance, securities firms, and pension funds, thus creating a sole supervisory authority with enhanced powers and, (ii) transfer the right to issue regulation from the new SSF to the BCR, to balance the power of the integrated supervisor, while focusing the oversight system on a financial stability objective. It also creates an appeal committee to ensure the rights of the governed with respect to sanctions.

43. When approved, the law would could enhance the timeliness of supervisory and regulatory decisions, improve consolidated supervision and reduce the scope for regulatory arbitrage, as well as and strengthen banks' corporate governance. In particular, the law:

- $\quad$ Broadens and clarifies the supervisory powers of the new SSF, as well as its governance and operational independence. It includes a comprehensive definition of supervision, encompassing inspection, control and a broader the range of corrective actions. It also establishes a new supervisory committee composed of only the Superintendent and the Intendents, which greatly limits potential political interference and may speed up 
supervisory decisions $^{18}$, and it strengthens the Superintendent's independence and legal protection with respect to resolution decisions. An integrated supervisory agency could improve consolidated supervision.

- $\quad$ Establishes a dedicated regulatory committee composed of BCR officials, BCR Board members and the Superintendent of the new SSF, which may improve the timeliness of issuing regulation. ${ }^{19}$ A sole regulator should facilitate the harmonization of regulations for similar risks taken by different types of financial institutions and thus reduce the scope for regulatory arbitrage.

- $\quad$ Requires enhanced intra-agency cooperation between the SSF and BCR with respect to the financial stability objective, which could allow for a more macroprudential perspective in regulation and supervision.

- Spells out the responsibilities of bank directors, managers and staff regarding disclosure, and management and internal controls to enhance banks' corporate governance.

44. Still, the current draft would benefit from stronger legal protection for supervisors and preemptive measures. The law only partially addresses the current lack of legal protection for supervisors, which still would be insufficient against litigation for supervisory actions undertaken in good faith. Also, despite the improvements in the remedial action framework, the SSF's room to maneuver preemptively remains restricted. In particular, it lacks the power to restrict dividends, activities or purchases prior to regularization. Furthermore, there is no requirement for a financial institution's board to inform the SSF of material operational problems.

45. The separation of regulatory and supervisory functions will require strong effective cooperation and coordination between the SSF and BCR. Under the proposed law, the BCR is the regulatory authority, while the new SSF provides inputs and proposals for regulations. However, the separation of regulation and supervision in two different authorities, while serving to check and balance the power of the integrated supervisory agency, is not typical and may reduce compliance with international standards. ${ }^{20}$ To avoid hampering the effectiveness of supervision, it is essential that the BCR acquire technical skills in the area of prudential

\footnotetext{
${ }^{18}$ Currently, supervisory decisions are take $\mathrm{n}$ by the SSF council, which includes representatives from government ministries (one from the Ministry of the Economy and one from the Ministry of Finance) that in theory creates the potential for political interference, although no such interference was found in practice. However, the SSF council is also the oversight body of the SSF and has become increasingly bogged down in operational and administrative matters.

${ }^{19}$ Banking regulations are currently issued by the SSF council, which suffers from the deficiencies noted in footnote 18. The new regulatory committee would still include a representative each from the Ministry of the Economy and of Finance however, these would be those on the Board of the BCR.

${ }^{20}$ This separation could reduce compliance with one of the essential criteria for the BCP 1.3 Legal Framework.
} 
supervision, and that BCR regulators work closely with SSF supervisors. This cooperation and coordination needs to be put into effect promptly in order to finalize existing draft regulations whose issuance is long overdue. Lastly, the SSF and BCR will need to establish who is responsible for responding to industry consultations on the interpretation of regulations, as well as how to resolve differences of interpretation between the SSF and banks as well as between the $\mathrm{SSF}$ and the BCR. The BCR, in coordination with the supervisory agencies, should develop formal mechanisms for addressing these challenges.

\section{In time, the merger of the three supervisory institutions is expected to reduce} supervisory gaps, but the integration process is not free from challenges. The merger should facilitate consolidated supervision and provide a more comprehensive view of the risks of the financial system. However, with the integration, it is important to not only pay attention to the banks that represent the highest risk to financial stability, but also to the rest of the financial sector to ensure sound financial development. The merger in itself will require the attention of key staff of the SSF over a long period of time, and a great deal of planning and careful implementation is needed to achieve a successful reorganization and integration of the cultures, systems and processes. The BCR, in coordination with the supervisory agencies, should develop a detailed action plan for addressing these challenges.

\section{SAFETY NETS}

\section{A. Systemic Liquidity and Emergency Liquidity Assistance}

\section{The BCR's systemic liquidity management is constrained by the limited range of} instruments with which it can effectively operate and lack of implementing regulations. Central banks in dollarized economies cannot provide liquidity in the same way as other central banks, as they cannot issue their own currency. However, they could use excess ("free") international reserves or borrowed external funds to inject liquidity into the system. The BCR is currently prohibited from lending to banks. Rather, the law only allows the BCR to conduct repos with securities held as part of the required liquid reserves (Art. 47B of the Banking Law) currently limited to BCR securities - as well as with BCR, government, and IGD securities when the government has deposited funds expressly for this purposed (Art. 49B of Banking Law (BL)). A 2000 amendment to the Organic Law of the BCR, also allows the central bank to sell or buy investments and loans from banks (Art. 49(b)), but the latter has proven very cumbersome in practice. However, regulations implementing the CBR's powers have not been issued.

\section{The system operates with high (and costly) levels of individual liquid assets. As a} legacy of a bank default in the late 1990s and the negative perception of interbank transactions held by supervisors, the domestic interbank is very limited and does not function efficiently or effectively. ${ }^{21}$ Furthermore, while banks' foreign parents could extend liquidity to their subsidiaries, this may not always be forthcoming unless it is an exceptional circumstance and

\footnotetext{
${ }^{21}$ A large spike in repo rates occurred at the end of 2008 due to a few small transactions (Figure 3). This led to increased market concerns about systemic risks.
} 
there is certainty about future macroeconomic policies (e.g., under an IMF program). In this context, individual liquid assets are high to provide self-insurance against liquidity shocks. ${ }^{22}$ However, this is very costly both for banks in terms of profitability and for the system in terms of foregone credit.

49. Several legal and operational constraints in providing liquidity assistance should be addressed to allow for timely emergency liquidity assistance. The prohibition against lending to banks (Central Bank Law Art. 51) should be lifted so that the BCR can temporarily channel excess reserves or external borrowed funds to solvent banks in line with best practices on emergency liquidity assistance. The approval of article 130 of the FSSRL would be useful in this respect. Furthermore, the BCR should issue the necessary regulations to implement the few options (e.g., repos, outright purchases) it currently has for providing and managing systemic liquidity. ${ }^{23}$ Also, the authorities should review the legal constraints to conducting repos with government securities, which under the commercial code definition of repos are considered government credit and thus prohibited (if not done with funds provided by the government itself). Finally, the BCR should design a collateral policy and define clearly the processes to carry out permissible operations.

\section{Furthermore, the government should provide resources to increase the BCR's} capacity to deal with systemic liquidity shocks. El Salvador's excess ("free") reserves are low relative to other dollarized economies in the region (Figure 10). ${ }^{25}$ Additional excess reserves would enhance the BCR's ability to provide liquidity to individual banks in situations of systemic liquidity stress (e.g., in order to purchase less liquid securities and assets or, if possible, lend using these assets as collateral). If possible, the authorities should consider allocating the SDR allocation granted in 2009 (half of it, or SDR69 million, currently deposited with the Treasury) to strengthen the BCR's balance sheet. Over the medium-term, the government should seek to fully capitalize the BCR. ${ }^{26}$

\section{The authorities should establish and implement a comprehensive systemic liquidity policy, which should include contingency plans and consideration of a liquidity fund. A}

\footnotetext{
${ }^{22}$ Stress tests show that these appear sufficient to withstand large withdrawals of 30 percent of deposits and no rollover of other liabilities coming due in one month, but some banks would rely on the BCR having government funds in order to repo government securities.

${ }^{23}$ Currently, the SSF is charged with regulating this requirement. This would change under the proposed FSSRL.

${ }^{25}$ Free reserves are those international reserves in excess of commercial banks claims on the BCR and which be needed to provide liquidity once a bank has exhausted its liquid reserve assets.

${ }^{26}$ The Treasury issued long-term bonds for US\$704 million to securitize a government liability with the BCR, but there is still an outstanding issue of bank resolution trust fund (FOSAFI) debt, arising from the purchase of failed bank assets from the late 1990s, that the government should honor.
} 
high-level financial stability committee, ${ }^{27}$ consisting of the MOF, BCR and SSF, should establish medium-term objectives for the stock and structure of systemic liquidity, criteria for the use of tools or mechanisms for the different stages of individual bank or systemic liquidity problems, and contingency plans. ${ }^{28}$ Setting up a liquidity fund, currently under consideration by the financial cabinet, would reduce the costs of liquidity protection for individual banks as well as for the economy. ${ }^{29}$ The liquidity fund would allow for pooling liquid resources, and would complement the still incipient interbank market and the limited capacity of the BCR to provide systemic liquidity. The availability of the pooled resources could reduce the volatility of domestic liquidity for individual banks and in turn reduce the need for self-insurance against liquidity shocks, while providing an additional buffer prior to accessing scarce public funds. Short of this, the SSF could require irrevocable letters of credit from parent banks to provide additional assurance of access to external liquidity.

\section{B. Problem Bank Resolution and Deposit Insurance}

\section{The Bank Law (BL) establishes criteria for regularization and restructuring of a} troubled financial institution, but timely action maybe hampered by lack of regulations and legal protection. The main triggers for regularization are: (i) a CAR below 10 percent; (ii) use of the third liquidity tranche; and (iii) other situations that put at risk the bank's solvency and liquidity (e.g. deficient risk management). During regularization-which has a term of 90 days but can be extended up to a total of 180 days under certain circumstances - the law authorizes the SSF to take a wide range of corrective actions. ${ }^{30}$ Failure to present a regularization plan, or noncompliance with a plan, would trigger restructuring (although the SSF can also impose a restructuring whenever the bank's situation puts depositors at risk). At this point, shareholders must adequately capitalize the banks within 30 days or else the SSF may use other mechanisms (see below) to resolve the bank. ${ }^{31}$ However, the lack of regulations on various risks and on sanctions - to clearly classify the severity of violations-limits enforcement of the regularization criteria. Furthermore, the SSF has not formally defined the responsibilities and intensity of follow-up of corrective actions, based on risks. These gaps may delay regularization or restructuring, in particular given the lack of legal protection for supervisors, which are in turn

\footnotetext{
27 The Banking Law establishes such a committee for the resolution of systemic banking crisis. The mandate of this committee could be expanded to include financial stability and crisis management issues more broadly (see section $\mathrm{C}$ for further discussion).

${ }^{28}$ The authorities have requested technical assistance in this area.

${ }^{29}$ Liquidity funds are already in place or being considered in the other dollarized economies in the region, i.e., in Ecuador and Panama, respectively.

${ }^{30}$ The SSF can (i) require a special external auditor's report and enforce the necessary identified adjustments (i.e., capitalize losses), (ii) place a special supervisor with veto right on the Board of Director's decisions, (iii) remove the Board of Directors and (iv) impose limit in terms of the investment and credit policies.
} 
likely to lead to greater asset dissipation and higher costs for the deposit insurance fund or for the government in case of a systemic banking crisis.

53. Furthermore, the bank resolution process also lacks implementing regulations and supportive institutional arrangements. In 2002, the BL incorporated new tools for bank resolution, allowing the SSF to use purchase and assumptions (P\&A) of assets and liabilities to resolve a bank, and allowing the participation of the Deposit Guarantee Fund (Instituto de Garantía de Depósitos, IGD) in these operations when it is necessary to protect guaranteed deposits. Since then, only one small bank was required to present a regularization plan, with no need to go through a resolution process since a private solution (it was acquired by a new bank). Nonetheless, supporting regulations such as establishing the eligibility criteria for participating in a P\&A have not been issued. Comprehensive procedures, manuals and standardized contracts (e.g. for trust funds constituted for P\&A), and staff trained in these procedures are also needed to facilitate an effective resolution. These should be discussed and mutually agreed by all the safety net providers involved in the resolution process (SSF, BCR and IGD).

54. The authorities should amend the legal framework to:

- Eliminate the requirement to notify a bank three days prior to the suspension of operations or other resolution measures. Such notification constitutes a significant obstacle to achieving a successful resolution (i.e., the preservation of the institution's cash and other valuable resources, such as contracts, registries, etc.)

- Introduce the least-cost solution (total amount of guaranteed deposits) as the measure of the maximum support by the IGD for a bank resolution. The current cost-benefit analysis requirement includes qualitative variables, such as the stability and confidence of the financial system. It is thus not bounded and exposes the IGD to legal challenges of its qualitative assessment.

- $\quad$ Remove the bank's Board upon the commencement of a bank's judicial intervention. The judicial receiver of an entity only has powers to transfer excluded assets and liabilities (determined by the SSF and IGD), while co-governing the bank with the Board. This could lead to potential conflicts, rending the resolution process unworkable.

- $\quad$ Allow a larger exclusion of assets than liabilities under the $\mathbf{P \& A}$ process to conserve scarce IGD resources. Valuing assets in a resolution process is subject to a high degree of uncertainty. Providing more upside potential increases the willingness of banks to assume deposits, as it minimizes the expected loss, and reduces the need for IGD support.

- Establish a deposit insurance reserve target and adopt measures to reinforce its funding. The current deposit insurance fee is one of the lowest in the region (Figure 11).

\footnotetext{
${ }^{31}$ With the prior favorable opinion of the BCR, the SFF can suspend the bank's operations, and can revoke the license if the bank is considered to be non-viable.
} 
Authorities should consider raising it, consistent with a reserve fund target calibrated to take account the characteristics and structure of the Salvadoran financial system (which is officially dollarized and highly concentrated). The fund should be able to make payouts of guaranteed deposits at all non-systemic banks that could fail over a given horizon. Furthermore, funding through the collection of pre-paid assessments on banks should be permitted and a regulation on the contingency funding of the IGD by the BCR should be issued.

\section{Financial Stability and Crisis Management Arrangements}

55. Coordination among the safety net providers should be strengthened and a financial stability strategy developed. An Inter-Institutional Financial System Committee (CISF)composed of representatives from BCR, IGD and financial sector superintendencies and organized along several technical working groups - exists (although not established formally by legislation or decree). However, roles and responsibilities are not fully developed and as a result the committee tends to be reactive to specific stress event. Projects are not formalized and the technical findings of the working groups do not generate coordinated strategic decisions. Furthermore, issues such as regulatory arbitrage, monitoring of unregulated financial intermediaries or market transactions, potential stress scenarios, among others that may impact financial stability, are not a regular part of the priorities of the various inter-institutional working groups. While the proposed law FSSRL would require the BCR and SSF to coordinate with respect to financial stability, specific policies and procedures for information sharing, systemic risk monitoring and crisis management still should be mutually agreed, formalized and implemented by all the safety net providers. The BCR should focus on macroprudential policies and monitoring, the SSF on microprudential issues, and the IGD on least-cost resolution, with clear, transparent and candid communication between them. A decree formally establishing the CISF and specifying its objective would be useful in this respect.

\section{Appropriate roles and responsibilities for resolving a systemic banking crisis should} also be established. Currently, the IGD must assess whether a bank failure could create systemic risk and financial instability, a role and responsibility beyond the mandate and competencies of the deposit insurer. Rather, the CISF should establish a methodology for defining systemic risk, based on different variables (size, interconnectedness, regional impact, contagion risk, payment system, etc.). A high-level stability committee, with technical inputs from the CISF, should decide on whether a systemic risk situation exists and how to proceed according to well defined roles and responsibilities. In particular, the MOF should take responsibility for financing systemic bank resolution, with appropriate transparency and accountability for the use of public funds.

\section{The authorities should carry out a comprehensive bank resolution simulation}

exercise. All the agencies involved in the process of bank resolution should be incorporated. Different stress scenarios should be considered and the results should be a used to make necessary legal, regulatory, and procedural changes. 


\section{FinANCIAL SECTOR INFRASTRUCTURE}

58. The recent launch of the RTGS system has reduced systemic risks, although the system is still exposed to operational risks. The RTGS system improved the integration between the BCR and banks and other financial institutions, allowing for a growing share of large-value payments to be channeled through this safer payments mechanism. However, the constraints on the BCR in providing liquidity expose the system to logjams if one bank cannot settle, and the lack of a contingency site to guarantee business continuity exposes the system to operational risks.

59. The Banking Law should be amended to allow for the free circulation of credit information among all the credit bureaus, as well as regionally. Currently, banks can access information gathered from the credit bureaus from all the sources (including credit unions, leasing companies, etc.), while nonbanks cannot access information provided by banks. Nonbanks should have reciprocity in order to ensure a comprehensive view of a client's debts. Over the long-term, more ambitious objectives could be set in terms of information sharing among the different existing databases in El Salvador, as well as in the region given the strong integration among Central American markets.

\section{FinAnCiAl SeCtor DeVelopMent AgEndA ${ }^{32}$}

\section{A. Role of Public Banks ${ }^{33}$}

60. The global financial crisis and ensuing credit crunch has revived the discussion on the role of public banks as a counter-cyclical and developmental tool. Salvadorian authorities are in the process of formulating a strategy for the public banking sector with a view to using these to limit the economy's dependence on foreign banks for funding domestic productive activities. State-owned first tier public banks were encouraged to expanded credit in 2009 to partially compensate for the credit contraction of some foreign banks (Figure 5). The authorities would like to further expand public banks' activities, in part by increasing the capital of first-tier banks and establishing a development fund to be intermediated by the second-tier bank. The source of these funds is still under discussion, however.

\section{A clearly defined strategy, consistent business plans, and performance measures} should be established for public banks. The government should define development objectives for the public banking sector and create coordination mechanisms among the three public banks to ensure complementarities of their business strategies, sources of funding, operational processes, and product lines. The business focus and strategy, industry and customer segments,

\footnotetext{
${ }^{32}$ While the FSAP also assessed access issues, the FSSA focuses on those aspects of the development agenda that are more likely to impact stability.

${ }^{33}$ The sector consists mainly of three institutions: a second-tier bank with a focus on long-term financing (Banco Multisectorial de Inversiones-BMI) and two small first-tier retail institutions with a focus on SMEs and small rural lending (Banco Hipotecario-BH and Banco de Fomento Agropecuario-BFA).
} 
and specific financial products of each bank should be a derived from these objectives. To clearly define targets and facilitate accountability, public financial institutions should formulate business plans and adopt performance measurement systems that combine both financial and social objectives.

62. In addition, public governance should ensure these banks preserve their recently restored financial solvency. In the past, public banks' portfolio quality has been substantially affected by governmental loan forgiveness programs for the agricultural sector, and the BFA and $\mathrm{BH}$ have required multiple recapitalizations, amounting to more than US\$300 million since 1991. To avoid the mistakes of the past, the government, as the owner of the public banks, should be unequivocally committed to preserve public banks' sustainability, by monitoring and holding bank managers accountable for results. Any subsidy component in the banks' operations should be clearly accounted for in the budget.

63. Risk management and supervision of public banks should be strengthened to accompany their planned growth. Public banks should be under the same regulatory conditions and supervision as any other bank in the system to ensure a level playing field and early identification of problems. A clear on-site schedule of visits and off site review of their financial information should be defined.

\section{B. Capital Markets}

\section{A weak and incomplete legal framework constrains local capital market} development, including through further integration with regional capital markets. Except for the Securitization Law (2007), the legal framework has not changed in the last decade. The Investment Funds Law has been in the making for more than 10 years, and the project to modernize the capital markets framework has been put on hold since 2005 due to differences between the government and the stock exchange. Further regional integration is constrained given differences in regulatory frameworks, with El Salvador having relatively weaker standards among the larger countries in the region (Panama and Costa Rica).

65. The current market rules and role of the stock exchange hampers market trading and the greater participation by institutional investors in securities markets. All products and players are required by regulation to be listed and traded on the domestic securities exchange, preventing the development of over-the-counter (OTC) markets. Furthermore, the exchange channels all local secondary market transactions through its members (supporting their brokerage services). Combined with the securities exchange's exclusive control of the only central depository, competition is limited, which raises trading costs. This includes unnecessary costs for transactions where brokerages add little value (e.g. the buying and selling of foreign securities between brokers and their clients). The limited trading reduces potential issuers' access to institutional investors, other than through initial public offerings, as these investors require more liquidity and transparency of market prices. 
66. To promote efficiency and sound development, the regulatory framework must be updated and the role of the exchange must be rationalized. A new and comprehensive Securities Law that elevate the standards of the market should:

- $\quad$ Eliminate the obligation for listing and trading in the exchange;

- $\quad$ Allow private placements targeted to institutional investors (registered in the SV) as well as OTC transactions;

- $\quad$ Eliminate the local rating requirements for foreign instruments rated in recognized jurisdictions;

- Grant the authorities powers to make the regulatory changes needed to expedite the regional integration (e.g. remote access, mutual recognition); and

- $\quad$ Minimize the self -regulatory framework given the small size of the market and the demutualization of the exchange.

67. The Investment Funds Law should be approved to broaden and diversify the investor base. Passage of the law would allow for the development of the mutual fund industry. This would greatly help issuers given the current reliance on two main institutional investors (pension funds and banks) and the maximum established limit of 35 percent for participation in security issuances. 
Table 1. El Salvador: Selected Economic Indicators

\begin{tabular}{|c|c|c|c|c|c|c|c|c|}
\hline & $\begin{array}{r}\text { Average } \\
2000-04\end{array}$ & $\begin{array}{r}\text { Average } \\
2005-09\end{array}$ & 2005 & 2006 & 2007 & 2008 & 2009 & $\begin{array}{c}\text { Standard } \\
\text { deviation } 1 /\end{array}$ \\
\hline & \multicolumn{8}{|c|}{ (Annual percent change) } \\
\hline Income and Prices & & & & & & & & \\
\hline Real GDP & 2.1 & 2.2 & 3.3 & 4.2 & 4.3 & 2.4 & -3.5 & 2.2 \\
\hline Consumer prices (end of period) & 3.3 & 3.9 & 4.3 & 4.9 & 4.9 & 5.5 & 0.0 & 1.9 \\
\hline \multirow[t]{2}{*}{ Terms of trade } & -3.0 & -1.6 & -2.9 & -0.9 & -5.7 & -10.2 & 11.8 & 5.8 \\
\hline & \multicolumn{8}{|c|}{ (Percent of GDP, unless otherwise stated) } \\
\hline \multicolumn{9}{|l|}{ External Sector } \\
\hline Current account balance & -3.1 & -4.6 & -3.5 & -4.2 & -6.0 & -7.6 & -1.8 & 1.9 \\
\hline Merchandis Trade & -14.5 & -17.9 & -17.1 & -18.8 & -20.1 & -19.9 & -13.5 & 2.8 \\
\hline Exports & 21.3 & 19.8 & 20.0 & 20.0 & 19.8 & 20.9 & 18.3 & 1.1 \\
\hline Imports & -35.8 & -37.7 & -37.1 & -38.9 & -40.0 & -40.7 & -31.8 & 2.8 \\
\hline Services and income & -3.6 & -4.5 & -4.1 & -3.9 & -4.3 & -5.1 & -5.2 & 0.6 \\
\hline Transfers & 14.9 & 17.8 & 17.6 & 18.5 & 18.4 & 17.3 & 16.9 & 1.8 \\
\hline Foreign direct investment (net) & 2.0 & 3.3 & 2.3 & 1.4 & 6.9 & 3.3 & 2.7 & 1.7 \\
\hline \multicolumn{9}{|l|}{ Nonfinancial Public Sector } \\
\hline Overall balance & -3.2 & -3.3 & -3.0 & -2.9 & -1.9 & -3.1 & -5.6 & 1.0 \\
\hline Gross public debt 2/ & 38.0 & 42.8 & 41.7 & 41.7 & 39.1 & 41.2 & 50.4 & 5.3 \\
\hline \multirow[t]{2}{*}{ Sovereign spread (basis points) } & 324.7 & 296.9 & 248.1 & 199.8 & 163.0 & 387.8 & 486.0 & 108.1 \\
\hline & \multicolumn{8}{|c|}{ (Annual percent change, unless otherwise stated) } \\
\hline \multicolumn{9}{|l|}{ Money and Credit } \\
\hline Credit to the private sector & 5.4 & 5.9 & 10.8 & 9.6 & 8.8 & 4.7 & -4.6 & 5.1 \\
\hline Private sector deposits & 1.4 & 7.1 & 4.2 & 11.4 & 17.4 & 0.1 & 2.3 & 6.3 \\
\hline Bank foreign liabilities & 24.5 & -12.2 & 0.8 & -13.5 & -22.5 & 19.8 & -45.7 & 28.4 \\
\hline Deposit interest rate, 180 days time deposits (percent) & 4.4 & 4.2 & 3.4 & 4.4 & 4.7 & 4.2 & 4.5 & 1.0 \\
\hline Lending interest rate, up to 1 year (percent) & 8.1 & 7.9 & 6.9 & 7.5 & 7.8 & 7.9 & 9.3 & 1.5 \\
\hline
\end{tabular}

Sources: Central Reserve Bank of El Salvador; Ministry of Finance; and Fund staff estimates. $1 /$ Over last ten years.

2/ Includes gross debt of the nonfinancial public sector and external debt of the central bank. 
Table 2. El Salvador: Financial System Structure

\begin{tabular}{|c|c|c|c|c|c|c|}
\hline & 2004 & 2005 & 2006 & 2007 & 2008 & 2009 \\
\hline \multicolumn{7}{|l|}{ Number } \\
\hline Banks & 14 & 13 & 13 & 13 & 12 & 13 \\
\hline Private domestic & 5 & 4 & 2 & - & - & - \\
\hline State-ow ned & 2 & 2 & 2 & 2 & 2 & 2 \\
\hline Foreign-ow ned & 5 & 5 & 7 & 9 & 8 & 9 \\
\hline Branch of foreign banks & 2 & 2 & 2 & 2 & 2 & 2 \\
\hline Other depository institutions* & 6 & 7 & 7 & 7 & 7 & 9 \\
\hline Other credit institutions & 8 & 10 & 10 & 10 & 9 & 9 \\
\hline Leasing comparies & 1 & 3 & 3 & 3 & 3 & 3 \\
\hline Factoring Companies & 2 & 2 & 2 & 2 & 2 & 2 \\
\hline Others & 5 & 5 & 5 & 5 & 4 & 4 \\
\hline Securities companies & 17 & 14 & 14 & 13 & 13 & 12 \\
\hline Pension funds & 3 & 2 & 2 & 2 & 2 & 2 \\
\hline Insurance & 19 & 18 & 18 & 18 & 18 & 20 \\
\hline Assets (In percent of total) & 100.0 & 100.0 & 100.0 & 100.0 & 100.0 & 100.0 \\
\hline Banks & 75.3 & 76.6 & 70.1 & 68.7 & 67.5 & 64.2 \\
\hline Private domestic & 61.4 & 53.6 & 35.5 & - & - & - \\
\hline State-ow ned & 2.9 & 3.0 & 2.7 & 2.7 & 3.1 & 3.1 \\
\hline Foreign-ow ned & 9.5 & 18.6 & 31.0 & 64.9 & 63.5 & 60.4 \\
\hline Branch of foreign banks & 1.5 & 1.4 & 0.9 & 1.0 & 0.8 & 0.7 \\
\hline Other depository institutions* & 1.4 & 2.1 & 2.0 & 2.1 & 2.3 & 2.8 \\
\hline Other credit institutions & 6.8 & 6.5 & 5.7 & 5.2 & 4.7 & 5.0 \\
\hline Leasing comparies & 0.0 & 0.0 & 0.1 & 0.1 & 0.1 & 0.1 \\
\hline Factoring Companies & 0.1 & 0.1 & 0.1 & 0.1 & 0.0 & 0.0 \\
\hline Others & 6.7 & 6.3 & 5.5 & 5.0 & 4.6 & 4.9 \\
\hline Securities companies & 0.1 & 0.2 & 0.1 & 0.1 & 0.1 & 0.1 \\
\hline Pension funds & 14.7 & 19.1 & 19.7 & 20.6 & 21.9 & 24.5 \\
\hline Insurance & 2.3 & 2.5 & 2.1 & 2.2 & 2.5 & 2.7 \\
\hline Loans & 100.0 & 100.0 & 100.0 & 100.0 & 100.0 & 100.0 \\
\hline Banks & 95.9 & 96.3 & 96.4 & 96.3 & 95.9 & 95.0 \\
\hline Private domestic & 77.5 & 66.5 & 66.0 & 48.3 & - & - \\
\hline State-ow ned & 3.2 & 3.0 & 3.1 & 3.5 & 4.0 & 4.5 \\
\hline Foreign-ow ned & 14.3 & 26.0 & 26.7 & 44.0 & 91.7 & 90.2 \\
\hline Branch of foreign banks & 1.0 & 0.8 & 0.6 & 0.5 & 0.2 & 0.2 \\
\hline Deposits & 100.0 & 100.0 & 100.0 & 100.0 & 100.0 & 100.0 \\
\hline Banks & 98.2 & 98.3 & 98.2 & 98.1 & 97.7 & 97.4 \\
\hline Private domestic & 78.6 & 66.8 & 49.5 & - & - & - \\
\hline State-ow ned & 4.6 & 4.6 & 4.0 & 3.9 & 4.8 & 4.6 \\
\hline Foreign-ow ned & 13.6 & 25.3 & 43.5 & 93.2 & 91.8 & 91.9 \\
\hline Branch of foreign banks & 1.4 & 1.6 & 1.2 & 1.0 & 1.1 & 0.8 \\
\hline \multicolumn{7}{|l|}{ Memorandum items: } \\
\hline \multicolumn{7}{|l|}{ Assets } \\
\hline In millions of dollars & $15,107.8$ & $15,457.6$ & $17,766.4$ & $19,851.6$ & $20,841.7$ & $21,051.5$ \\
\hline In percent of GDP & 95.6 & 90.6 & 95.2 & 97.4 & 94.2 & 97.8 \\
\hline \multicolumn{7}{|l|}{ Deposits } \\
\hline In millions of dollars & $6,997.8$ & $7,104.6$ & $7,786.0$ & $9,096.7$ & $9,014.4$ & $9,316.2$ \\
\hline In percent of GDP & 44.3 & 41.6 & 41.7 & 44.7 & 40.8 & 43.3 \\
\hline \multicolumn{7}{|l|}{ Loans } \\
\hline In millions of dollars & $6,546.4$ & $7,277.1$ & $8,229.0$ & $9,026.0$ & $9,319.6$ & $8,722.2$ \\
\hline In percent of GDP & 41.4 & 42.6 & 44.1 & 44.3 & 42.1 & 40.5 \\
\hline
\end{tabular}

Source: Superintendencia del Sistema Financiero. Note: 1. Information correspond to regulated institutions only. 2. There are no records of collective investment schemes such as mututal funds, investment trusts and investment managers. * includes cooperative banks and regulated federations of cooperatives (2004-2009) and 2 savings and loans societies (starting in 2009) 
Table 3. El Salvador: Capital Markets

(US\$ million, unless otherwise stated)

\begin{tabular}{|c|c|c|c|c|c|}
\hline & 2005 & 2006 & 2007 & 2008 & 2009 \\
\hline Government securities & $4,478.2$ & $4,417.5$ & $4,634.5$ & $5,617.7$ & $6,054.9$ \\
\hline of which Eurobonds & $3,440.0$ & $3,290.0$ & $3,240.0$ & $3,240.0$ & $4,040.0$ \\
\hline $\begin{array}{l}\text { Government securities } \\
\text { (\% of GDP) }\end{array}$ & 26.0 & 23.6 & 22.7 & 25.4 & 28.7 \\
\hline \multicolumn{6}{|l|}{ Corporate bonds } \\
\hline Outstanding Volume & 909.6 & 823.0 & $1,021.8$ & $1,052.8$ & $1,137.4$ \\
\hline $\begin{array}{l}\text { Number of Outstanding } \\
\text { Issues }\end{array}$ & 41 & 40 & 38 & 44 & 40 \\
\hline Number of New Issues & 10 & 6 & 3 & 8 & 5 \\
\hline \multicolumn{6}{|l|}{ Equity Markets } \\
\hline $\begin{array}{l}\text { Number of Listed } \\
\text { Companies }\end{array}$ & 39 & 39 & 42 & 41 & 40 \\
\hline Number of New Listings & 4 & 1 & 3 & 0 & 3 \\
\hline Market Capitalization & $3,683.0$ & $5,352.0$ & $6,048.0$ & $5,398.0$ & $5,195.0$ \\
\hline $\begin{array}{l}\text { Market Capitalization (\% } \\
\text { of GDP) }\end{array}$ & 21.4 & 28.5 & 29.7 & 24.4 & 24.6 \\
\hline
\end{tabular}

Source: BCR and El Salvador Securities Commission. 
Table 4. El Salvador: Financial Soundness Indicators

\begin{tabular}{|c|c|c|c|c|c|c|}
\hline & 2005 & 2006 & 2007 & 2008 & 2009 & $\begin{array}{l}\text { Feb. } \\
2010\end{array}$ \\
\hline \multicolumn{7}{|l|}{ Capital adequacy } \\
\hline Regulatory capital to risk-weighted assets ${ }^{*}$ & 13.5 & 13.8 & 13.8 & 15.1 & 16.5 & 16.8 \\
\hline Regulatory Tier I capital to risk-weighted assets* & 10.4 & 10.6 & 10.9 & 12.1 & 13.6 & 13.7 \\
\hline Capital to total assets & 7.4 & 7.7 & 7.8 & 8.5 & 9.3 & 9.2 \\
\hline Leverage ratio $2 /$ & 7.1 & 7.4 & 7.4 & 8.1 & 8.9 & 8.9 \\
\hline \multirow{2}{*}{\multicolumn{7}{|c|}{$\begin{array}{l}\text { Asset composition } \\
\text { Sectoral distribution of loans to total loans* }\end{array}$}} \\
\hline & & & & & & \\
\hline Households & 43.0 & 44.0 & 47.0 & 50.0 & 52.0 & 53.0 \\
\hline Agricultural sector & 3.9 & 3.7 & 3.7 & 4.0 & 3.8 & 3.6 \\
\hline Mining sector & 0.0 & 0.0 & 0.3 & 0.3 & 0.3 & 0.3 \\
\hline Electricity, water, services, oil and gas sector & 1.3 & 1.1 & 1.4 & 1.7 & 1.5 & 1.5 \\
\hline Construction sector & 7.7 & 6.2 & 5.7 & 5.5 & 5.4 & 5.6 \\
\hline Transportation and communications sector & 1.4 & 1.9 & 1.9 & 2.0 & 2.5 & 2.6 \\
\hline Non-residents & 6.0 & 5.2 & 5.5 & 4.4 & 3.7 & 3.9 \\
\hline \multicolumn{7}{|l|}{ Geographical distribution of loans to total loans } \\
\hline Domestic & 94.9 & 95.1 & 95.8 & 95.6 & 96.7 & 96.7 \\
\hline Foreign & 5.1 & 4.9 & 4.2 & 4.4 & 3.3 & 3.3 \\
\hline Central America 3/ & 4.7 & 4.4 & 3.9 & 3.5 & 3.0 & 2.9 \\
\hline United States & 0.3 & 0.5 & 0.3 & 0.3 & 0.3 & 0.3 \\
\hline \multicolumn{7}{|l|}{ Asset quality } \\
\hline NPL to gross total loans ${ }^{*} 4 /$ & 2.0 & 1.9 & 2.1 & 2.8 & 3.7 & 3.9 \\
\hline Specific provisions to gross total loans & 2.5 & 2.3 & 2.5 & 3.2 & 4.2 & 4.4 \\
\hline NPLs net of provisions to capital* & -3.4 & -2.1 & -2.9 & -1.8 & -2.7 & -2.6 \\
\hline Loans at risk to total loans $5 /$ & 4.5 & 4.2 & 5.2 & 6.7 & 10.0 & \\
\hline \multicolumn{7}{|l|}{ Earnings and profitability } \\
\hline $\mathrm{ROAA}^{*}$ (annualized) & 1.4 & 1.8 & 1.5 & 1.2 & 0.4 & 0.8 \\
\hline $\mathrm{ROAE}^{*}$ (annualized) & 12.9 & 16.6 & 13.4 & 10.7 & 3.4 & 5.9 \\
\hline Net interest income to gross income ${ }^{*}$ & 77.2 & 81.3 & 79.8 & 76.3 & 76.8 & 78.2 \\
\hline Noninterest expenses to gross income ${ }^{*}$ & 50.3 & 48.6 & 47.0 & 48.7 & 51.3 & 48.7 \\
\hline Personnel expenses to noninterest expenses & 52.1 & 54.4 & 53.4 & 52.0 & 50.6 & 51.2 \\
\hline $\begin{array}{l}\text { Spread between reference loan and deposit rates } \\
\text { (bps) }\end{array}$ & 301.0 & 275.0 & 328.0 & 420.0 & 477.0 & 501.0 \\
\hline \multicolumn{7}{|l|}{ Liquidity } \\
\hline Liquid assets ratio $6 /$ & 33.5 & 32.3 & 34.0 & 35.8 & 41.3 & 41.8 \\
\hline Customer deposits to total (non-interbank) loans & 97.2 & 94.2 & 100.1 & 95.6 & 105.1 & 105.0 \\
\hline
\end{tabular}

Source: BCR, SSF and staff calculations.

* Included in the "core and encouraged set" of FSls.

$1 /$ Includes public commercial banks

2/ Tier 1 capital to total on- and off-balance sheet assets.

3/ Excluding Belize and Panama.

4/ Loans past-due more than 90 days.

$5 /$ Including restructured and refinanced loans.

6/ Liquid reserves plus liquid asset to deposits and other bank liabilities. 
Table 5. El Salvador: Regional Comparisons of FSIs

\begin{tabular}{|c|c|c|c|c|c|c|}
\hline & 2004 & 2005 & 2006 & 2007 & 2008 & 2009 \\
\hline & \multicolumn{6}{|c|}{ Return on assets (percent) } \\
\hline El Salvador & 1.0 & 1.2 & 1.5 & 1.2 & 1.0 & 0.3 \\
\hline \multirow[t]{2}{*}{ Other Central America 1/ } & 2.1 & 2.1 & 2.2 & 2.3 & 2.3 & 1.7 \\
\hline & \multicolumn{6}{|c|}{ Return on equity (percent) } \\
\hline El Salvador & 10.9 & 11.8 & 14.6 & 11.3 & 8.7 & 2.8 \\
\hline \multirow[t]{2}{*}{ Other Central America 1/ } & 23.4 & 22.8 & 23.5 & 23.8 & 23.1 & 16.3 \\
\hline & \multicolumn{6}{|c|}{ Nonperforming loans (percent of gross loans) } \\
\hline El Salvador & 2.3 & 1.9 & 1.9 & 2.1 & 2.8 & 3.7 \\
\hline \multirow[t]{2}{*}{ Other Central America 1/ } & 3.6 & 3.2 & 2.6 & 2.3 & 2.7 & 3.1 \\
\hline & \multicolumn{6}{|c|}{ Provisions to NPLs } \\
\hline El Salvador & 132.2 & 126.6 & 116.1 & 120.0 & 110.4 & 109.9 \\
\hline \multirow[t]{2}{*}{ Other Central America 1/ } & 121.0 & 123.7 & 130.7 & 121.1 & 104.5 & 105.5 \\
\hline & \multicolumn{6}{|c|}{ Capital adequacy ratio } \\
\hline El Salvador & 13.4 & 13.5 & 13.8 & 13.8 & 15.1 & 16.5 \\
\hline \multirow[t]{2}{*}{ Other Central America 1/ } & 14.9 & 14.2 & 13.8 & 13.2 & 14.0 & 15.1 \\
\hline & \multicolumn{6}{|c|}{ Liquid assets $2 /$} \\
\hline El Salvador & 36.1 & 33.5 & 32.3 & 34.0 & 35.7 & 41.3 \\
\hline Other Central America 1/ & 47.9 & 46.0 & 43.5 & 38.3 & 37.4 & 40.7 \\
\hline
\end{tabular}

Sources: National Sources; and Central American Monetary Council.

1/ Simple average of Costa Rica, Dominican Republic, Guatemala, Honduras, Nicaragua, and Panama.

2/ Cash and investments as percent of immediate liabilities and deposits. 
Table 6. El Salvador: Commercial Banking System Liquidity

(as of Feb. 2010)

\begin{tabular}{|c|c|c|c|c|c|c|c|c|}
\hline & \multicolumn{3}{|c|}{ Dollarized economies } & \multicolumn{5}{|c|}{ Non-dollarized economies } \\
\hline & SLV & PAN & $\mathrm{ECU}$ & CRI & GTM & HND & NIC & Average \\
\hline Total liquidity & 39.7 & 35.2 & 41.2 & 40.6 & 45.2 & 36.2 & 56.0 & 44.5 \\
\hline Most liquid & 33.0 & 31.9 & 37.2 & 27.6 & 17.5 & 21.8 & 31.8 & 24.6 \\
\hline Deposits at Central Bank & 15.2 & 1.3 & 6.9 & 16.9 & 10.1 & 11.7 & 22.6 & 15.3 \\
\hline Deposits abroad & 5.6 & 18.0 & 17.3 & 4.1 & 4.8 & 8.8 & 9.0 & 6.7 \\
\hline Securities abroad & 1.3 & 12.6 & 12.9 & 6.6 & 2.6 & 1.2 & 0.2 & 2.7 \\
\hline Subject to funding constraints & 4.9 & 2.7 & 0.6 & 10.9 & 25.1 & 11.5 & 19.4 & 16.7 \\
\hline Central government securities & 4.9 & 2.7 & 0.6 & 7.6 & 14.5 & 2.1 & 6.9 & 7.8 \\
\hline Holdings of Central Bank securities & 10.9 & 0.0 & 0.1 & 3.4 & 10.6 & 9.4 & 12.4 & 8.9 \\
\hline Operational liquidity (cash) & 1.8 & 0.6 & 3.4 & 2.0 & 2.7 & 3.0 & 4.8 & 3.1 \\
\hline Central Bank NIR not included above & 2.9 & 6.0 & 22.3 & 7.3 & 13.9 & 10.4 & 35.0 & 16.7 \\
\hline
\end{tabular}

Sources: IMF, International Financial Statistics; and Fund staff calculations.

Table 7. El Salvador: Bank Exposure to Foreign Assets

(In millions of U.S. dollars, unless otherwise stated)

\begin{tabular}{|c|c|c|c|c|}
\hline & \multicolumn{2}{|c|}{ March 2010} & \multicolumn{2}{|c|}{ March 2009} \\
\hline & $\begin{array}{r}\text { Total } \\
\text { exposure }\end{array}$ & $\begin{array}{l}\text { Exposure to } \\
\text { parent bank }\end{array}$ & $\begin{array}{r}\text { Total } \\
\text { Exposure }\end{array}$ & $\begin{array}{l}\text { Exposure to } \\
\text { parent bank }\end{array}$ \\
\hline Deposits & 585 & 156 & 285 & 46 \\
\hline Loans & 321 & 3 & 382 & \\
\hline Financial Investments & 213 & 17 & 493 & 43 \\
\hline Total & 1,119 & 175 & 1,160 & 90 \\
\hline Percent of capital & 76 & 12 & 80 & 6 \\
\hline
\end{tabular}

Sources: BCR, SSF and staff calculations. 
Table 8. El Salvador: Actual and Stressed NPLs by Sector

\begin{tabular}{|c|c|c|c|c|}
\hline Sector/Scenario & $\begin{array}{r}\text { Dec. } 2008 \\
\text { (actual) } \\
\end{array}$ & $\begin{array}{r}\text { Dec. } 2009 \\
\text { (actual) } \\
\end{array}$ & $\begin{array}{l}\text { Dec. } 2010 \\
\text { (estimate) }\end{array}$ & $\begin{array}{l}\text { Dec. } 2011 \\
\text { (estimate) }\end{array}$ \\
\hline \multicolumn{5}{|l|}{ Consumer } \\
\hline Baseline & 11.9 & 17.0 & 19.2 & 13.8 \\
\hline Downside &.. &.. & 22.9 & 17.1 \\
\hline Extreme &.. & .. & 29.9 & 27.9 \\
\hline \multicolumn{5}{|l|}{ Mortgage } \\
\hline Baseline & 10.6 & 13.4 & 31.2 & 18.5 \\
\hline Downside &.. & .. & 34.3 & 23.3 \\
\hline Extreme & .. &.. & 39.4 & 50.3 \\
\hline \multicolumn{5}{|l|}{ Manufacturing } \\
\hline Baseline & 16.5 & 17.6 & 52.2 & 40.8 \\
\hline Downside & .. & .. & 52.9 & 53.5 \\
\hline Extreme & .. & .. & 57.1 & 79.3 \\
\hline \multicolumn{5}{|l|}{ Primary Sector } \\
\hline Baseline & 23.2 & 23.4 & 47.6 & 36.4 \\
\hline Downside &.. & .. & 48.3 & 41.5 \\
\hline Extreme & .. & .. & 51.5 & 58.4 \\
\hline \multicolumn{5}{|l|}{ Construction } \\
\hline Baseline & 20.3 & 29.9 & 48 & 33 \\
\hline Downside &.. & .. & 49.6 & 40.3 \\
\hline Extreme & .. & .. & 59.5 & 69.6 \\
\hline \multicolumn{5}{|l|}{ Retail } \\
\hline Baseline & 13.6 & 17.9 & 34.1 & 25 \\
\hline Downside & .. & .. & 34.1 & 27.7 \\
\hline Extreme & .. & .. & 34.1 & 42.9 \\
\hline \multicolumn{5}{|l|}{ Transportation } \\
\hline Baseline & 5.6 & 10.2 & 13.9 & 17.5 \\
\hline Downside & .. &.. & 14.4 & 17.7 \\
\hline Extreme & .. & .. & 17.4 & 26.7 \\
\hline \multicolumn{5}{|l|}{ Other Services } \\
\hline Baseline & 13.8 & 19.1 & 30.1 & 23 \\
\hline Downside & .. &.. & 31.1 & 27.4 \\
\hline Extreme &.. & .. & 37.8 & 48 \\
\hline \multicolumn{5}{|l|}{ TOTAL } \\
\hline Baseline & $\ldots$ & 17.2 & 31.4 & 22.2 \\
\hline Downside & $\ldots$ & $\ldots$ & 33.5 & 27 \\
\hline Extreme & $\ldots$ & $\ldots$ & 38.6 & 46.3 \\
\hline
\end{tabular}

Source: SSF and staff estimates. 
Table 9. El Salvador: Stress Tests Results

\begin{tabular}{|c|c|c|c|c|c|c|}
\hline \multirow[t]{3}{*}{$\begin{array}{l}\text { CAR (as of December 2009) } \\
\text { Adjusted for goodwill and other intangibles }\end{array}$} & \multicolumn{6}{|l|}{$\begin{array}{l}16.5 \\
16.2\end{array}$} \\
\hline & \multicolumn{3}{|c|}{ Stressed Capital Adequacy Ratio (CAR) } & \multicolumn{2}{|c|}{ Number of Banks } & \multirow[b]{2}{*}{$\begin{array}{l}\text { Bank(s) under } \\
10 \%>20 \% \text { of } \\
\text { system assets? }\end{array}$} \\
\hline & Dec. 2010 & Dec. 2011 & $\begin{array}{l}\text { largest } \\
\text { decline } 1 /\end{array}$ & $\begin{array}{l}\mathrm{CAR}<12 \% \\
10 \%<\mathrm{CAR} \\
\end{array}$ & $\mathrm{CAR} \leq 10 \%$ & \\
\hline \multicolumn{7}{|l|}{ Credit Risk } \\
\hline Baseline Scenario & 14.0 & 14.7 & 9.2 & 1.0 & 0.0 & No \\
\hline Downside Scenario & 13.3 & 13.9 & 7.1 & 0.0 & 1.0 & No \\
\hline Extreme Scenario & 12.6 & 11.5 & 10.0 & 2.0 & 3.0 & Yes \\
\hline Downgrade of 100 largest debtors by one letter grade & 13.2 & - & 3.0 & 3.0 & 0.0 & No \\
\hline Downgrade of 100 largest debtors by two letter grades & 11.6 & - & 5.7 & 4.0 & 2.0 & Yes \\
\hline Default of 5 largest debtors & 11.1 & - & 4.3 & 2.0 & 3.0 & Yes \\
\hline Default of 10 largest debtors & 9.2 & - & 7.6 & 1.0 & 4.0 & Yes \\
\hline Haircut of $25 \%$ on guarantees of 100 largest debtors & 12.8 & - & 1.9 & 4.0 & 0.0 & No \\
\hline \multicolumn{7}{|l|}{ Interest-Rate (Repricing) Ris k } \\
\hline Interest rates increase by 1.5 percentage points & 13.5 & - & 5.8 & 3.0 & 0.0 & No \\
\hline \multirow[t]{3}{*}{ Interest rates increase by 3.0 percentage points } & 13.1 & - & 6.1 & 2.0 & 1.0 & No \\
\hline & \multicolumn{5}{|c|}{ Remaining liquid assets (\% of liabilities withdrawn) } & \\
\hline & & Aggregate & $\begin{array}{l}\text { Lowest } \\
\text { individual } \\
\text { coverage } \\
(\%)\end{array}$ & $\begin{array}{r}\text { Number } \\
\text { accessing } \\
\text { trar }\end{array}$ & $\begin{array}{l}\text { of banks } \\
3^{\text {rd }} \text { liquidity } \\
\text { che }\end{array}$ & $\begin{array}{l}\text { Bank(s) accessing } \\
3 \text { rd tranche }> \\
20 \% \text { of system } \\
\text { assets? }\end{array}$ \\
\hline \multicolumn{7}{|l|}{ Liquidity Risk } \\
\hline Withdrawal of $15 \%$ of deposits within 30 days & & 405.0 & 296.0 & & 0 & No \\
\hline Withdrawal of $30 \%$ of deposits within 90 days & & 165.0 & 117.0 & & 0 & Yes \\
\hline
\end{tabular}

Sources: BCR, SSF and staff estimates.

1/ Over either 1 year period. 
Figure 1. El Salvador: Economic Integration with United States
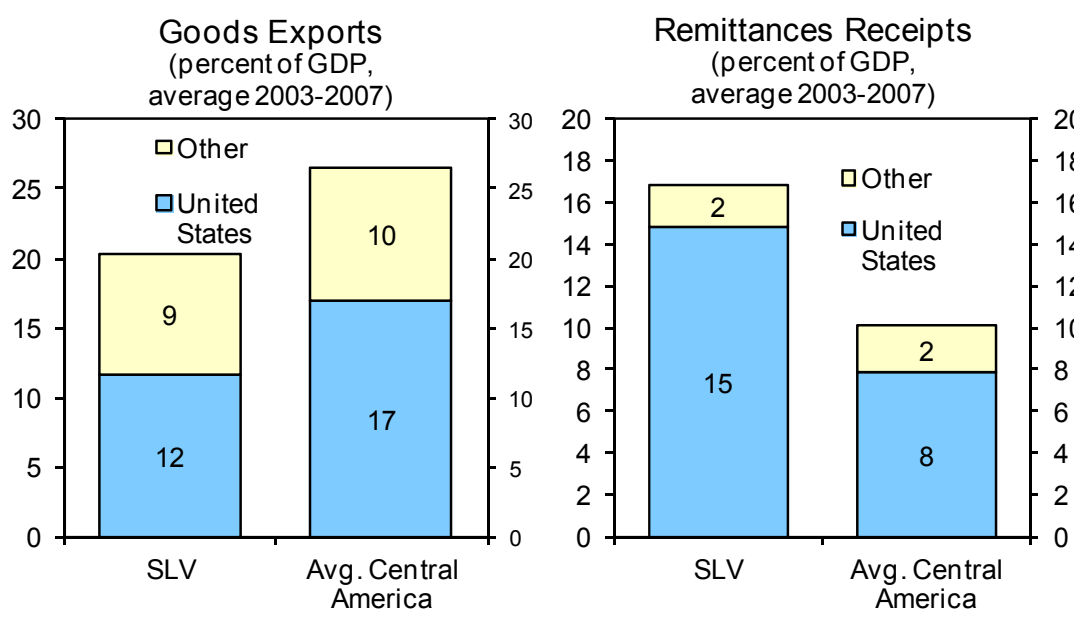

Claims of BIS-reporting Banks (percent of GDP, end-2007)

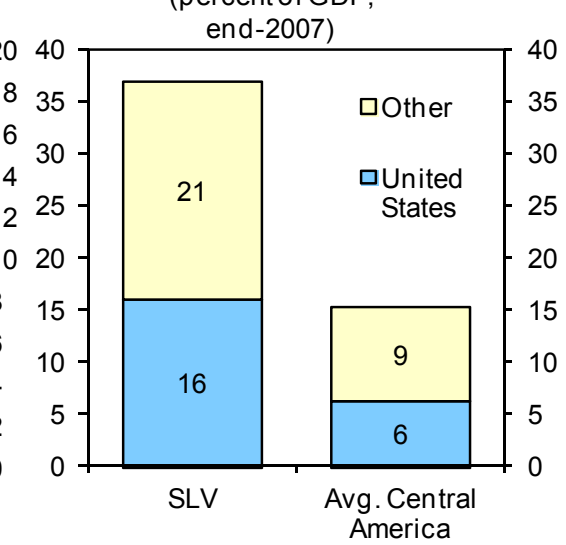

Sources: Bank for International Settlements; Haver Analytics; IMF, Direction of Trade Statistics; IMF, World Economic Outlook; National Sources; and FSAP Analysis. 
Figure 2. El Salvador: Macroeconomic Fundamentals

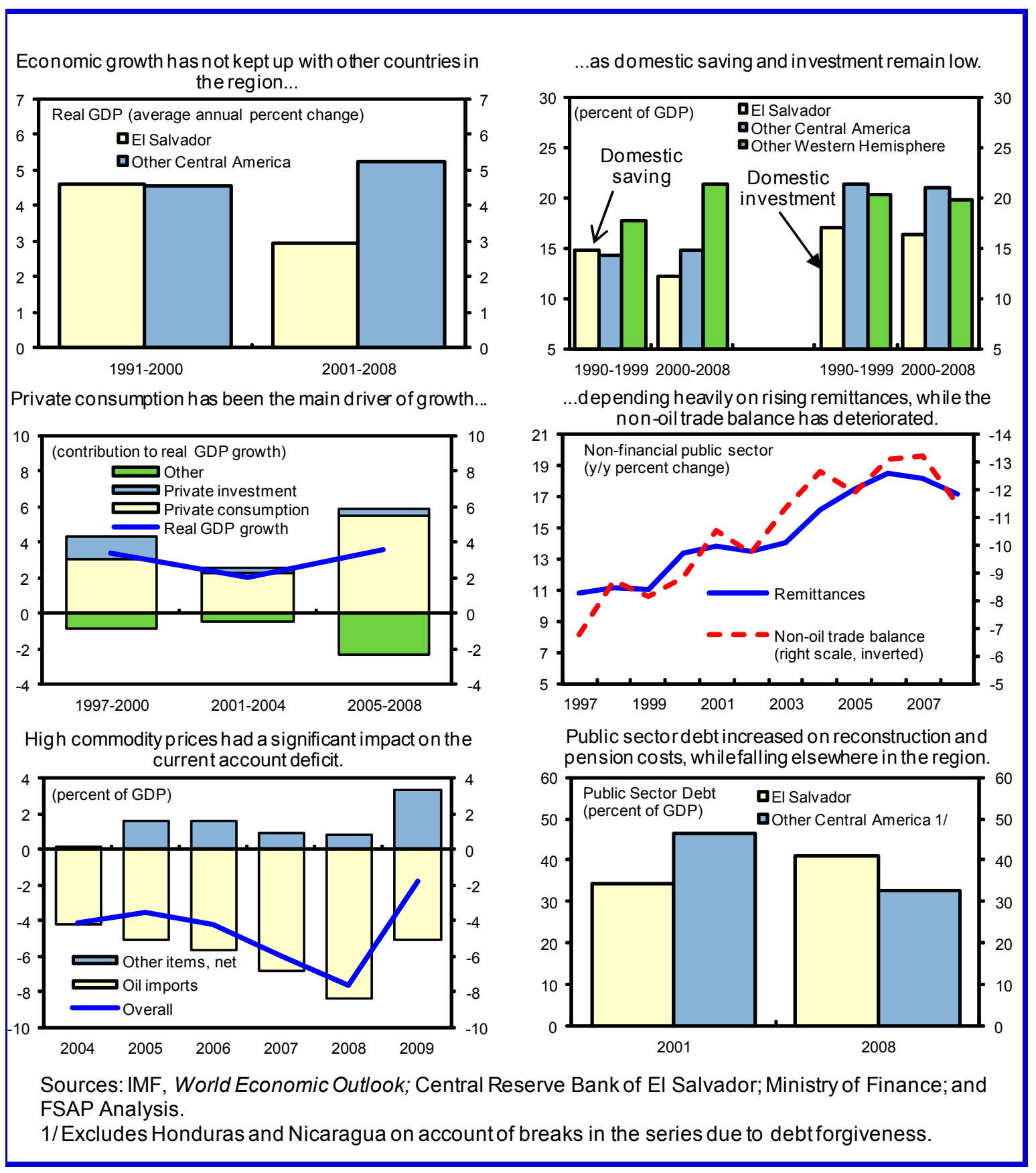


Figure 3. El Salvador: Recent Macroeconomic Developments

The global recession weighed on activity more than in the

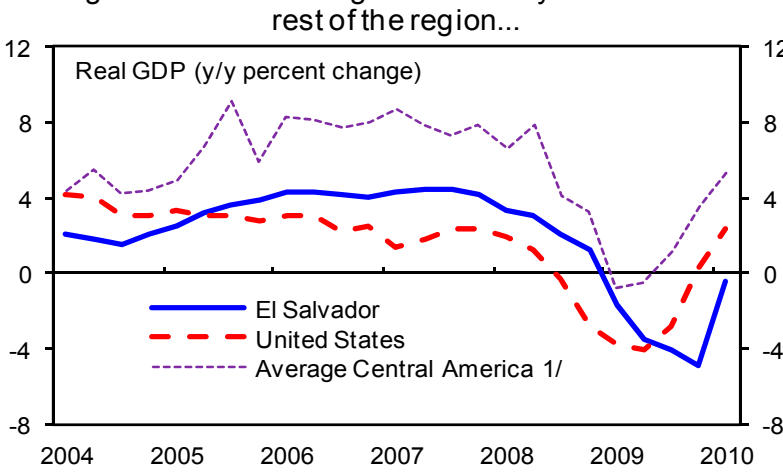

The slowdown in external demand and income cut trade, remittances,...

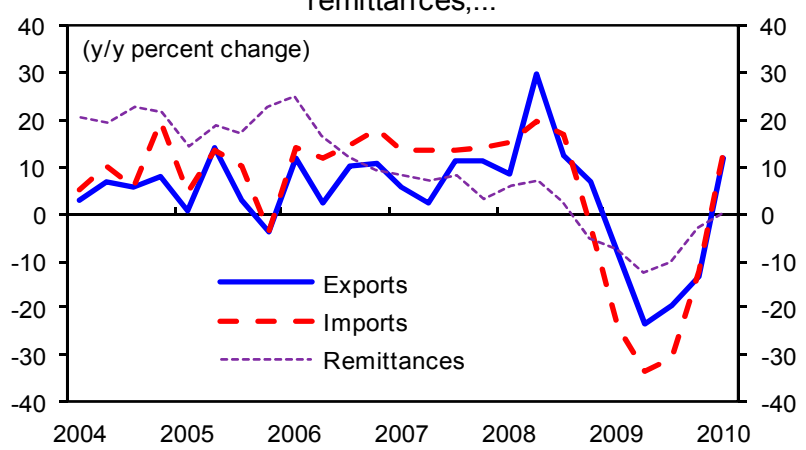

Tax revenue declined, while expenditure was maintained to mitigate the recession...

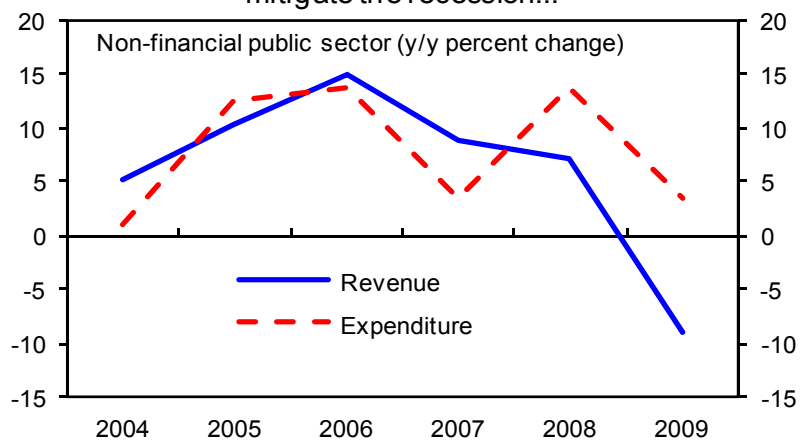

Cred it declined amid incresed risk aversion and recession, while deposits recovered after the elections.

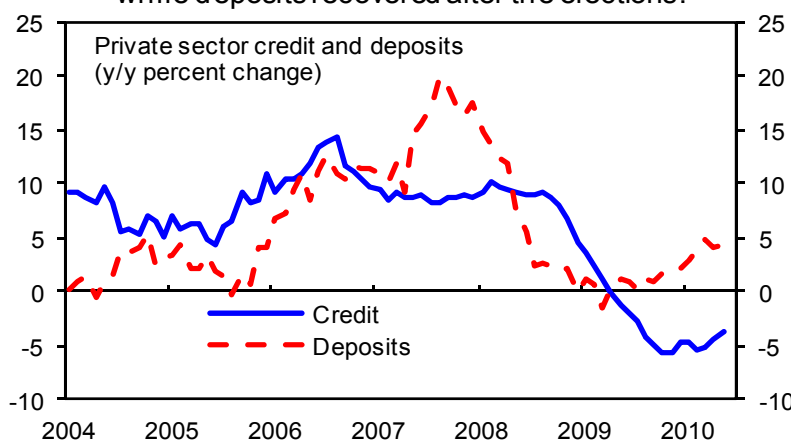

....and briefly brought in flation into negative territory.

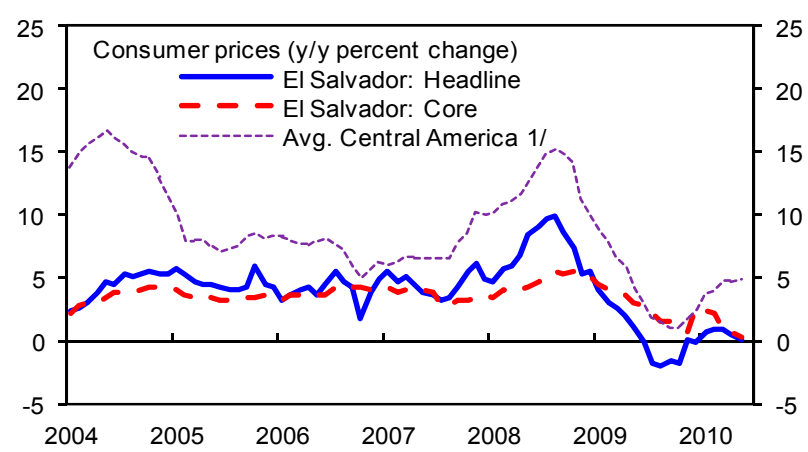

...and private debt flows, while FDI and public sector flows remained positive.

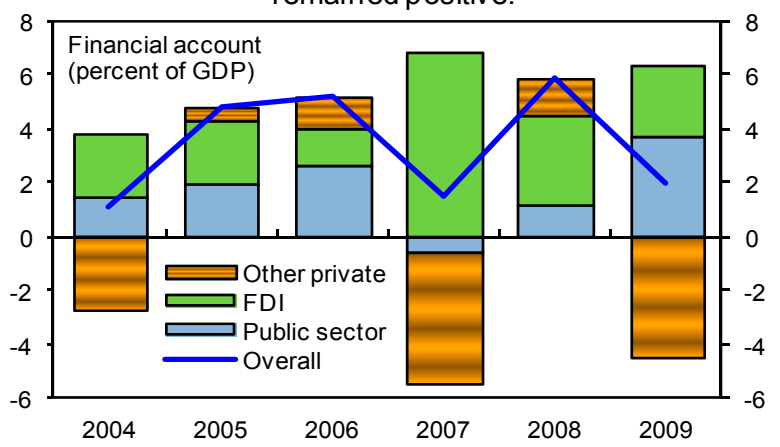

...raising the public sector deficit and debt-to-GDP ratio.

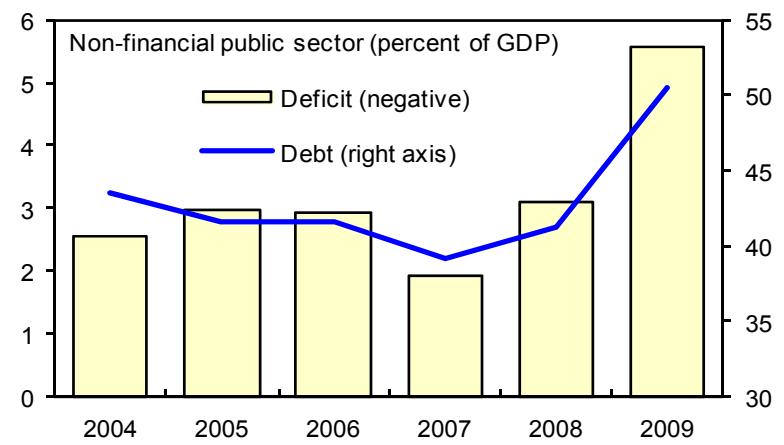

Interest rates, which had risen during the global crisis, have returned to pre-crisis levels.

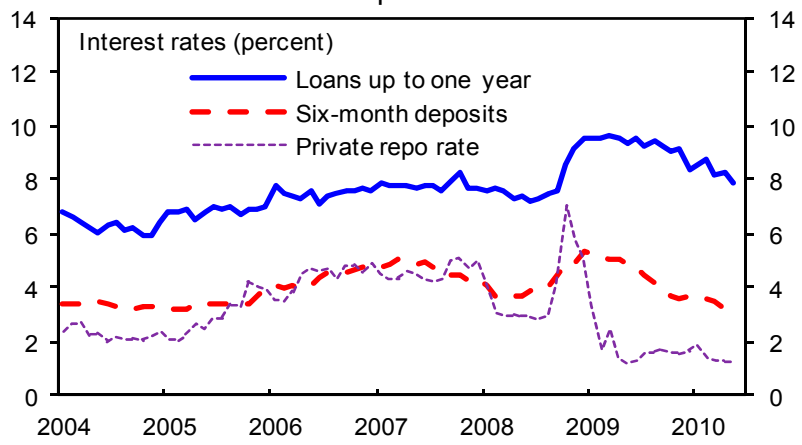

Sources: Haver Analytics; National Sources; IMF, World Economic Outlook; and FSAP Analysis.

1/ Includes Costa Rica, the Dominican Republic, Nicaragua, and Panama for quarterly real GDP and adds Guatemala and Honduras for consumer prices. 
Figure 4. El Salvador: Evolution of the Financial Sector

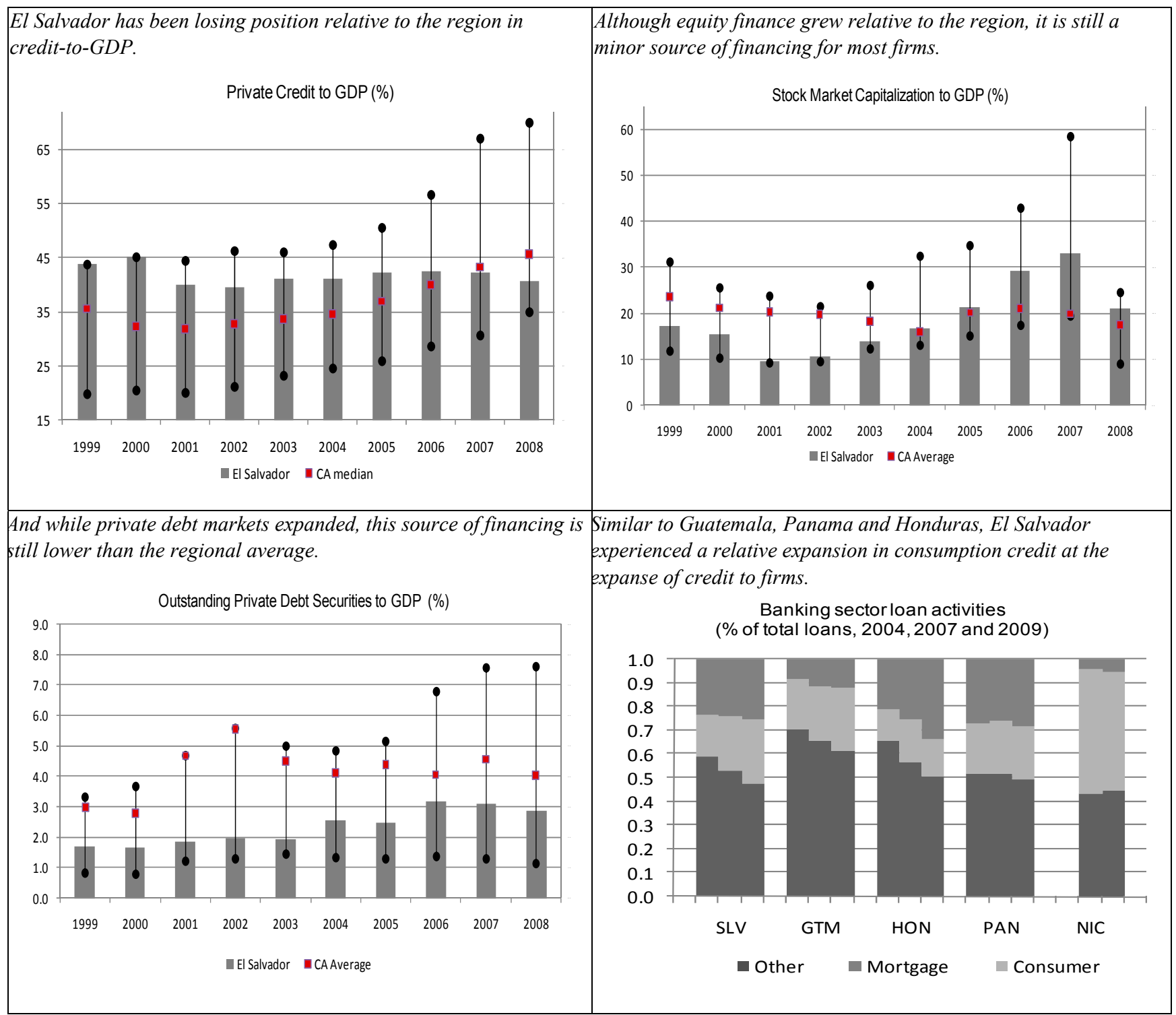

Source: Worldbank FINSTATS, and Superintendencias Financieras 
Figure 5. El Salvador: Credit Trends at Large and Public Banks (Credit-to-GDP)

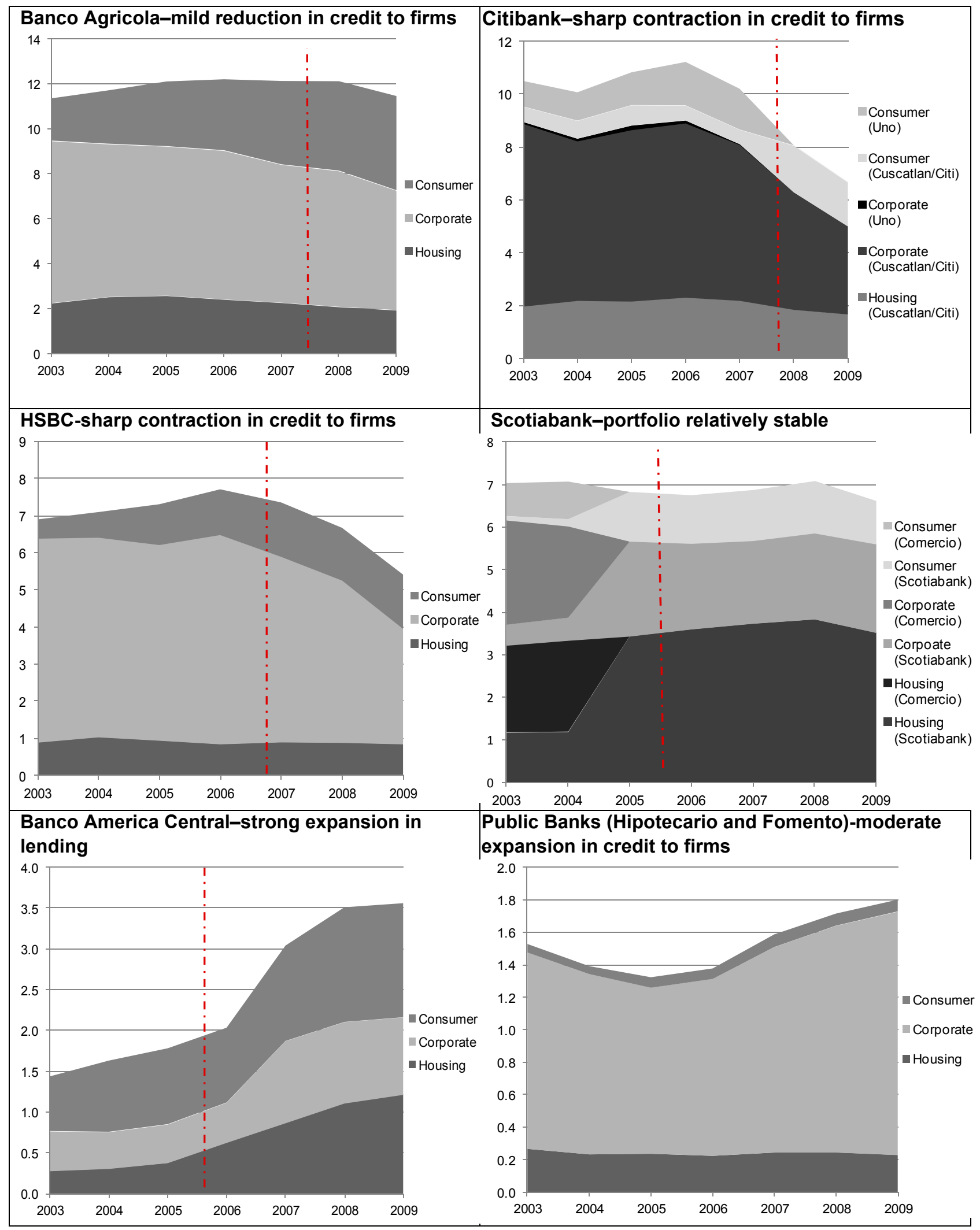

Source: SSF and staff calculations. 
Figure 6. El Salvador: Banking Sector Developments

Banks have cut lending and external bo rrowing..

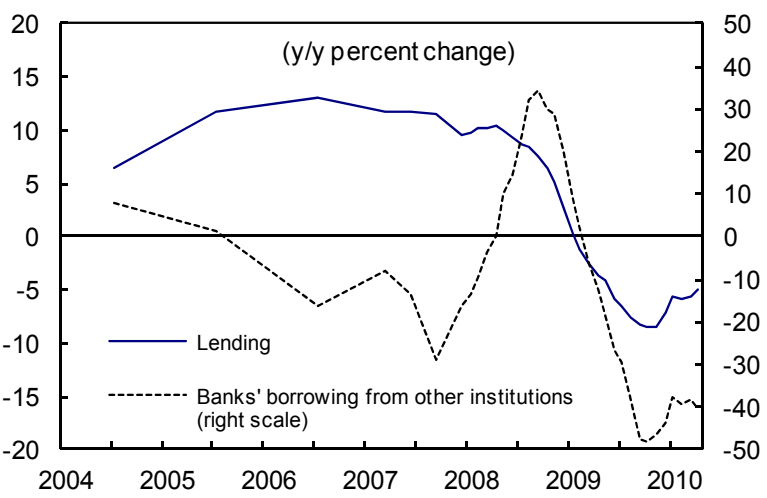

Nevertheless, deposit growth only recovered after the elections.

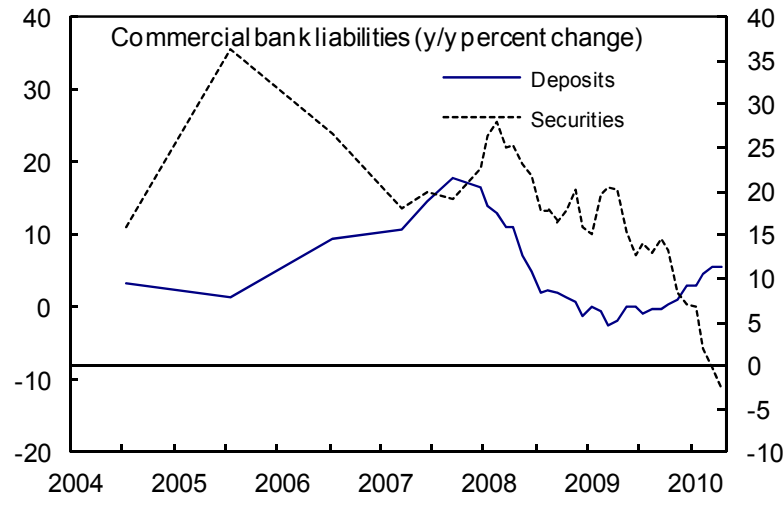

....and lowered profitability...

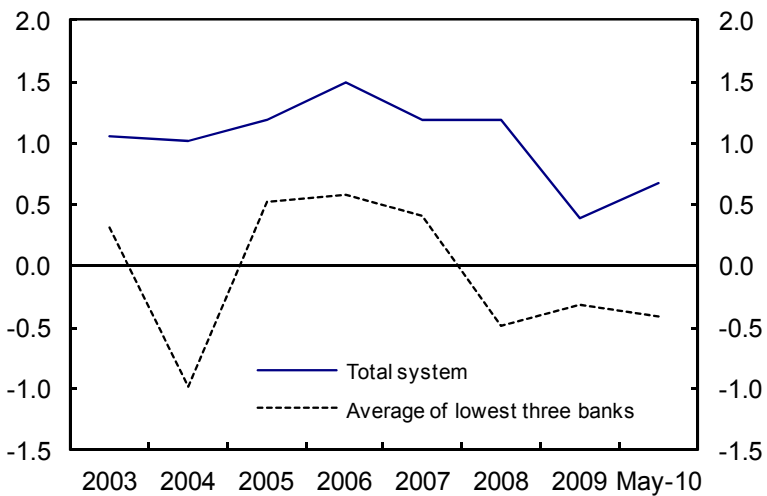

....increased liquid asset holdings, and raised deposit rates.

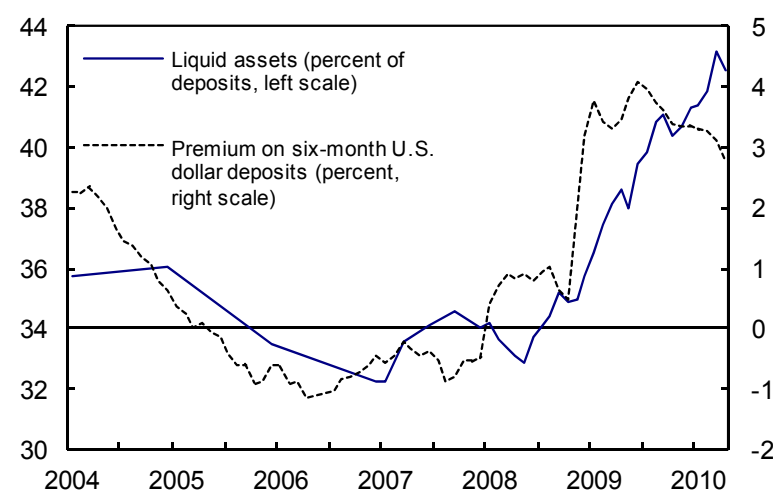

The economic downturn has caused non-performing loans and provisions to rise...

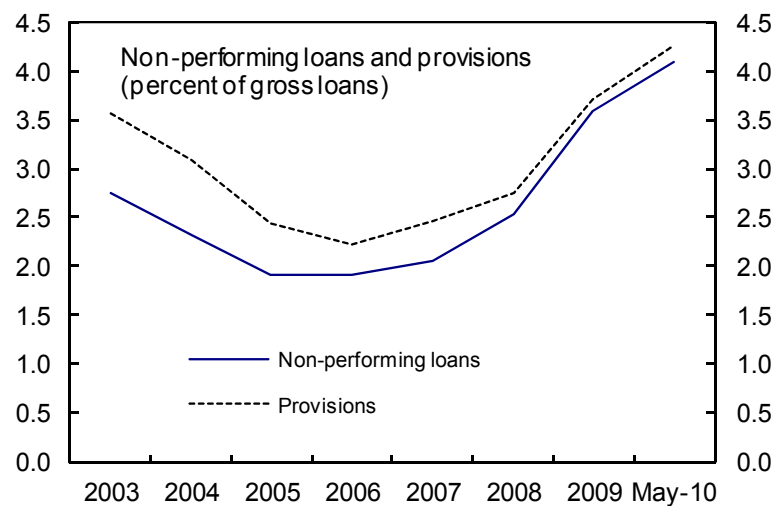

...although all banks remain above the regulatory capital minimum.

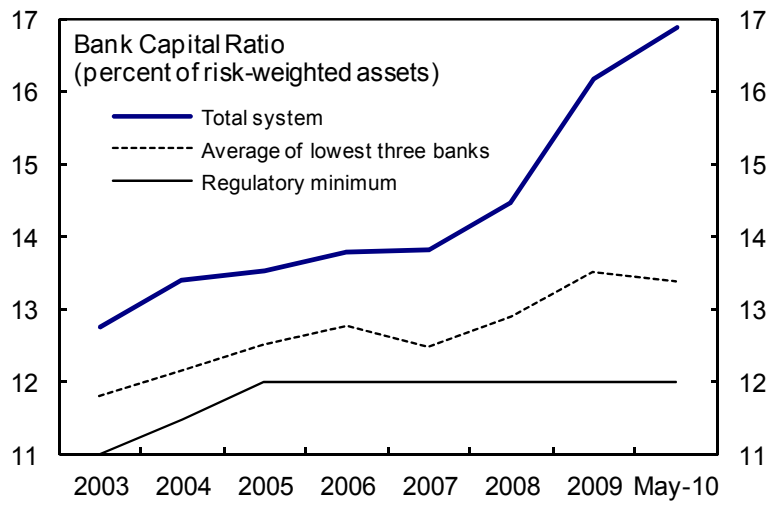

Sources: SSF; BCR; Haver Analytics; and Fund staff calculations. 
Figure 7. El Salvador: Non-Financial Corporate Sector Financing and Selected FSIs

Corporates rely much more heavily on bank than market financing.

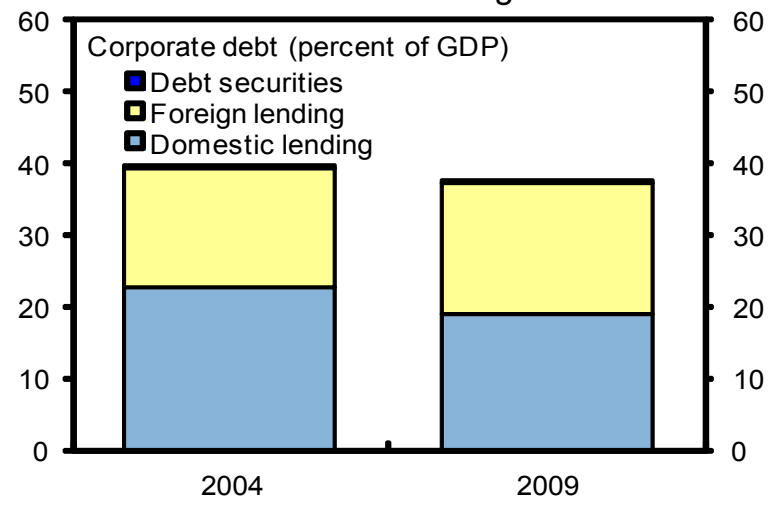

For large firms, the recesssion brought lower

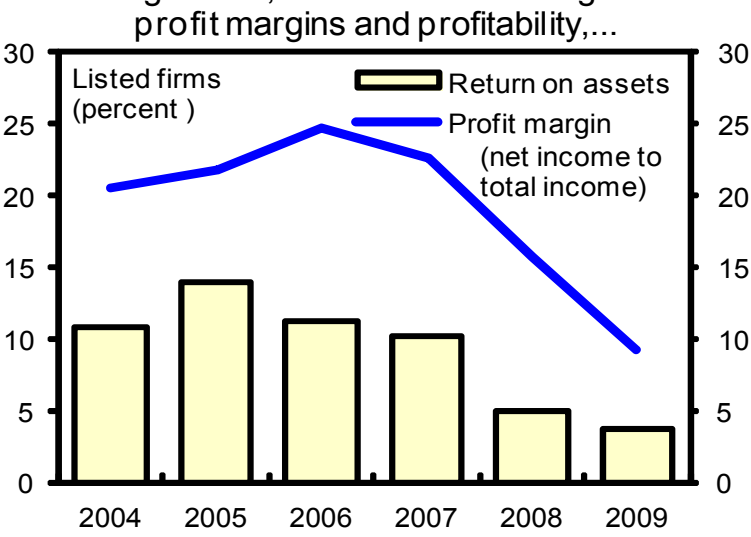

FDI has recently been focused on financial sector acquistions.

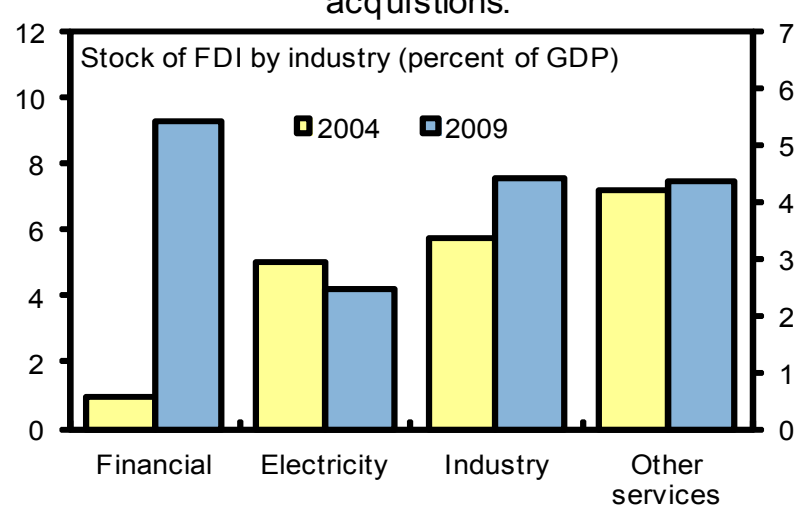

....and a deterioration in credit quality.

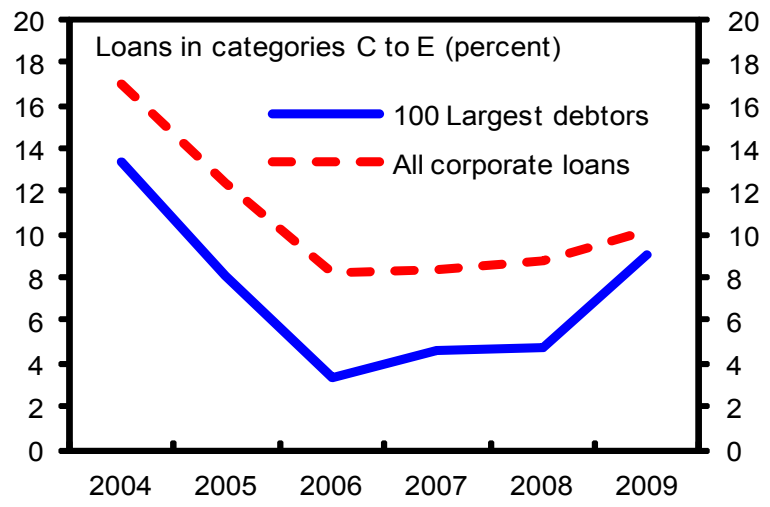

Sources: Superintendency of Securities; Superintendency of the Financial System; Central Reserve Bank of El Salvador; and FSAP Analysis. 
Figure 8. El Salvador: Banks' Liquidity Ratios /1 (percent of deposits)

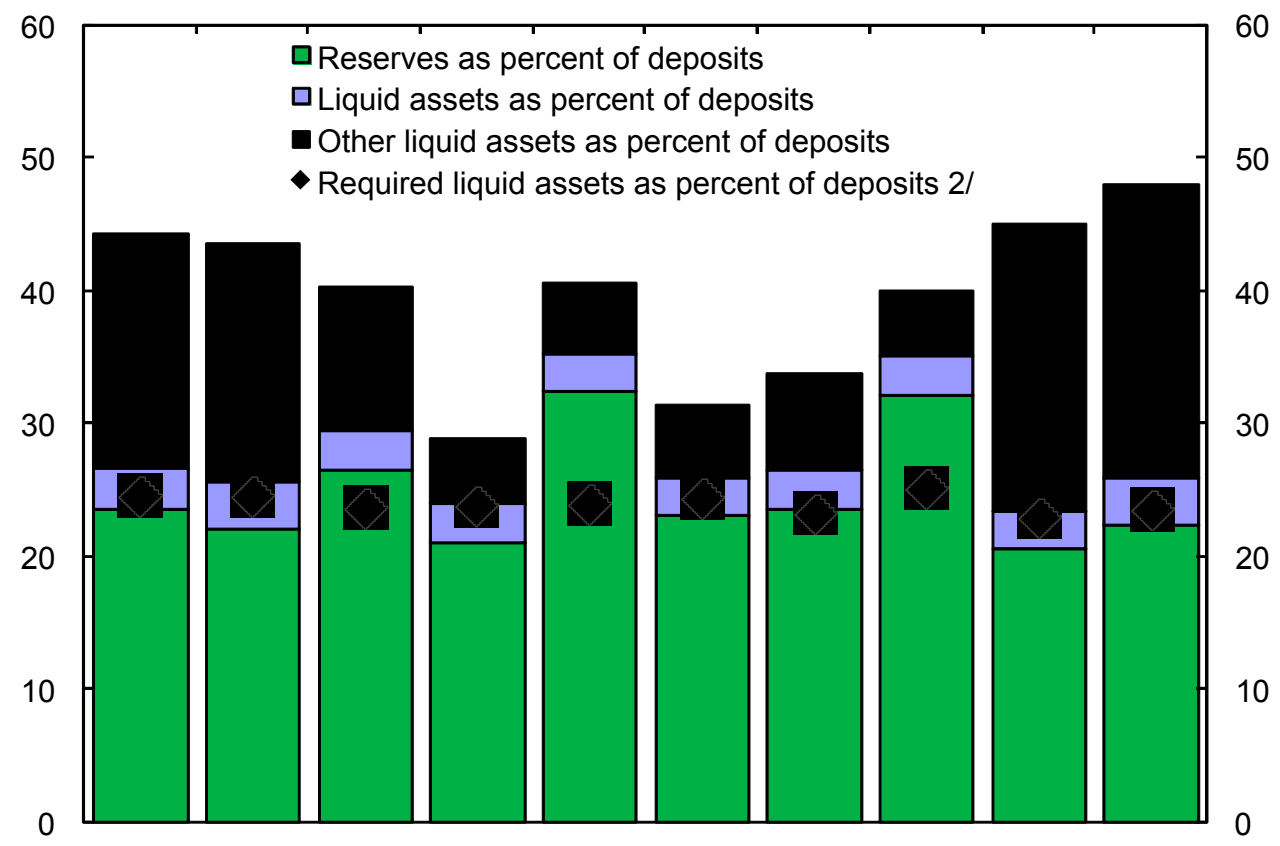

Source: BCR

$1 /$ Excludes branches.

2/ Required liquidity reserves plus required liquid assets.

Figure 9. El Salvador: Deposit Withdrawals During 2004 Election Period (Percent of deposits)

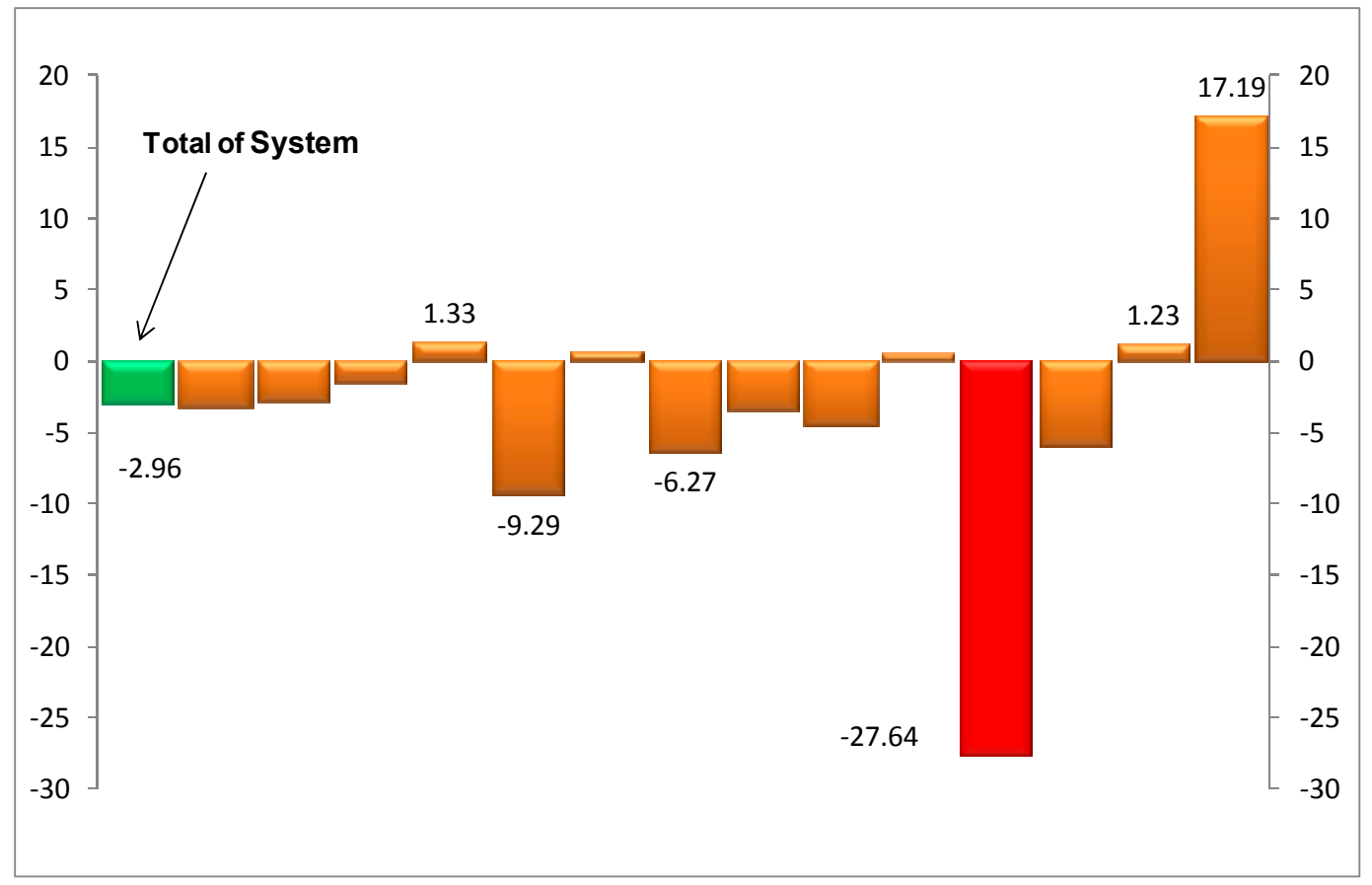

Source: BCR. 
Figure 10. El Salvador: Liquidity in Dollarized Economies

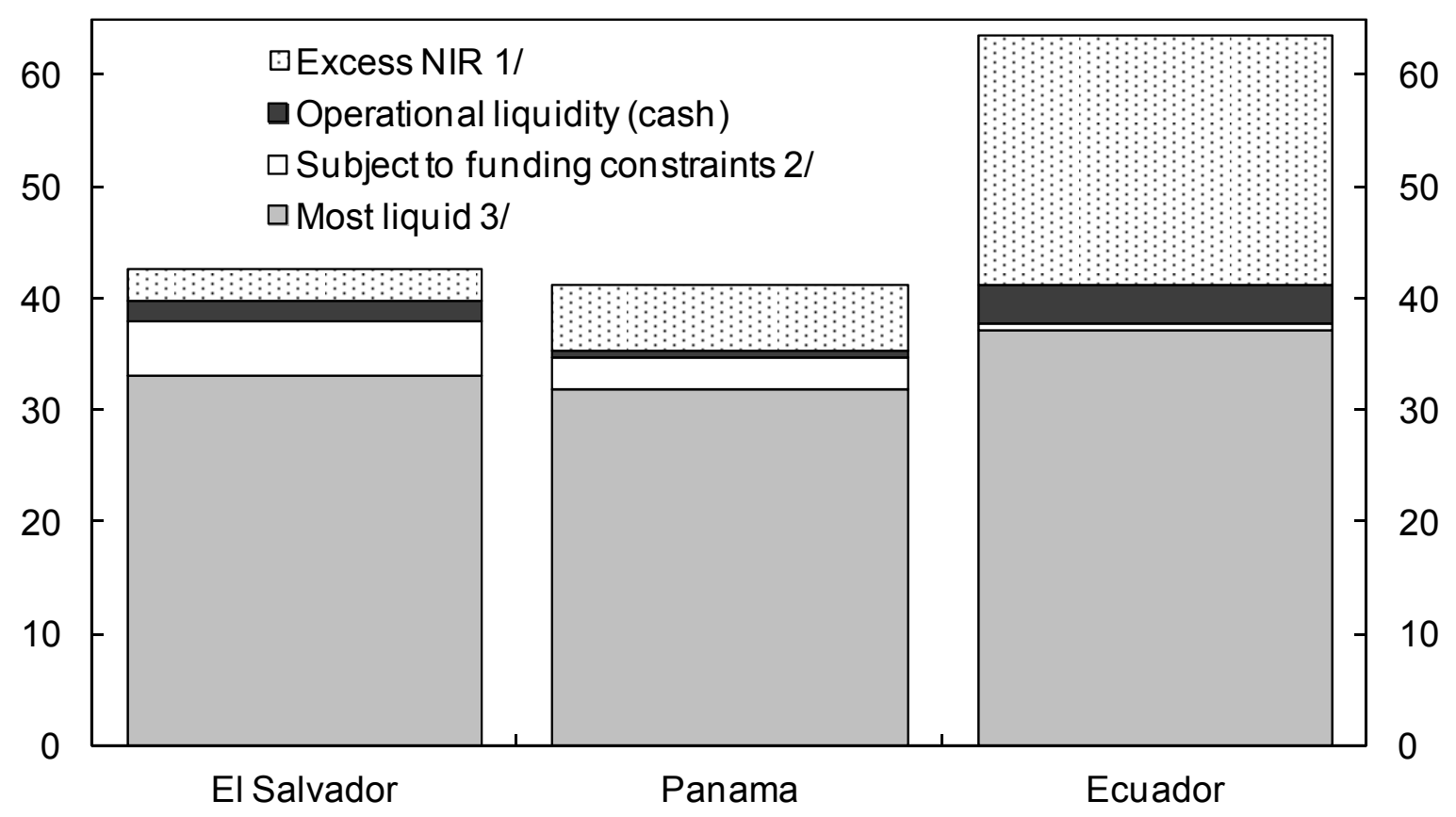

Sources: IMF, International Financial Statistics, and Fund staff calculations.

$1 /$ Net international reserves in excess of commercial bank claims on the monetary authority.

2/ Commercial bank holdings of central government securities.

3/ Deposits at the monetary authority, central bank securities, and deposits abroad. 
Figure 11. El Salvador: Deposit Insurance Minimum Contribution Rate, as of January 2010

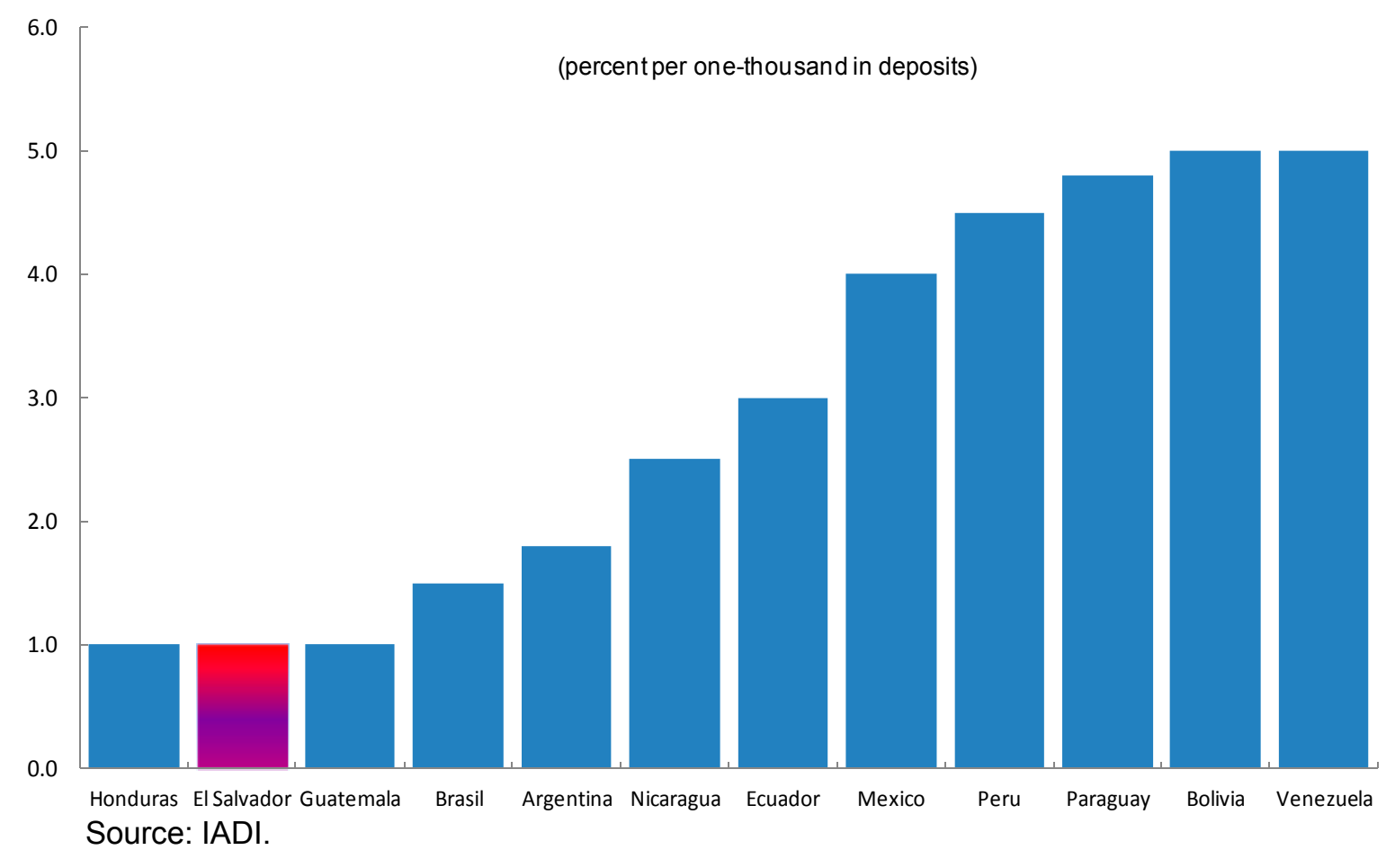




\section{Appendix I. EI Salvador: Implementation of the 2004 FSAP Recommendations}

\section{Main Recommendations}

\begin{tabular}{|c|c|}
\hline 2004 Recommendation & Current Status \\
\hline \multicolumn{2}{|l|}{ A. Role of the Central Bank } \\
\hline $\begin{array}{l}\text { - Capitalize central bank paper and government } \\
\text { deposits at the BCR }\end{array}$ & $\begin{array}{l}\text { Partially Implemented: The Treasury issued long-term } \\
\text { bonds for US\$704 million to securitize a government } \\
\text { liability with the BCR, but there is still an outstanding } \\
\text { issue of bank resolution trust fund (FOSAFI) debt, arising } \\
\text { from the purchase of failed bank assets from the late } \\
\text { 1990s, that the government by law should honor. }\end{array}$ \\
\hline - $\quad$ Build up international reserves & $\begin{array}{l}\text { Not Implemented: Excess ("free") reserves (i.e., net } \\
\text { international reserves minus Monetary Base): } \\
\text { Dec. 2004: US\$303 million. } \\
\text { Feb 2010: US\$251 million }\end{array}$ \\
\hline $\begin{array}{l}\text { - Assess the personnel deployment and functions of } \\
\text { the BCR }\end{array}$ & $\begin{array}{l}\text { Partially implemented: Assessed for national accounts, } \\
\text { statistics and balance of payments tasks. }\end{array}$ \\
\hline \multicolumn{2}{|l|}{ B. Strengthening bank regulation and supervision } \\
\hline $\begin{array}{l}\text { - Provide legal protection for Superintendent and } \\
\text { SSF staff }\end{array}$ & $\begin{array}{l}\text { Not Implemented: Legal framework is unchanged. The } \\
\text { draft law includes provisions on legal protection for bank } \\
\text { resolution, but is not adequate. }\end{array}$ \\
\hline $\begin{array}{l}\text { - Establish the tenure and terms for removal of the } \\
\text { Superintendent of the SSF }\end{array}$ & Not Implemented: legal framework is unchanged. \\
\hline $\begin{array}{l}\text { - Adopt enforcement policy, graduating sanctions } \\
\text { according to gravity of breaches }\end{array}$ & Not Implemented: legal framework is unchanged. \\
\hline $\begin{array}{ll} & \text { Specify division of powers between } \\
\text { Superintendent and SSF Board }\end{array}$ & Not Implemented: legal framework is unchanged. \\
\hline $\begin{array}{l}\text { - Provide powers to suspend distribution of } \\
\text { dividends }\end{array}$ & Not Implemented: legal framework is unchanged. \\
\hline - $\quad$ Improve loan classification & Implemented: new regulation effective as of 2007. \\
\hline $\begin{array}{l}\text { - } \quad \text { Bring provisioning rules more in line with } \\
\text { international good practice }\end{array}$ & Implemented: new regulation effective as of 2007. \\
\hline $\begin{array}{l}\text { - } \quad \text { Reduce participation threshold from } 50 \text { to } \\
20 \text { percent to require consolidation of accounts }\end{array}$ & Not implemented: Legal framework is unchanged. \\
\hline $\begin{array}{l}\text { - } \quad \text { Follow up on MoUs with other regional } \\
\text { supervisors to share information on conglomerates }\end{array}$ & $\begin{array}{l}\text { Implemented: use of regional committee and MOUs } \\
\text { observed in practice. }\end{array}$ \\
\hline $\begin{array}{l}\text { Provide powers to inspect the books of non- } \\
\text { financial related parties }\end{array}$ & Not implemented: Legal framework is unchanged. \\
\hline $\begin{array}{l}\text { - Increase reserves of the deposit insurance fund to } \\
5 \text { percent of insured deposits }\end{array}$ & $\begin{array}{l}\text { Not implemented*: IGD funds as percent of: } \\
\text {-insured deposits are } 4.2 \text { percent; and } \\
\text {-total deposits are } 1.1 \text { percent. } \\
\text { *Status should be compared to total deposit, consistent } \\
\text { with paragraph } 44 \text { of } 2004 \text { FSAP. }\end{array}$ \\
\hline $\begin{array}{l}\text { - Adopt contingency plans to coordinate official } \\
\text { action among BCR, IGD, and SSF on weak bank } \\
\text { resolution }\end{array}$ & $\begin{array}{l}\text { Partially Implemented: BCR, SSF and IGD coordinate } \\
\text { with respect to sharing information on stress tests and } \\
\text { early warning indicators, but better coordination is } \\
\text { hampered by the lack of regulation, procedures and } \\
\text { manuals, as well as training. }\end{array}$ \\
\hline $\begin{array}{l}\text { - Limit rights of investors to assets owned by off- } \\
\text { balance sheet vehicles }\end{array}$ & Not implemented: No further action undertaken. \\
\hline $\begin{array}{l}\text { - Require regular and transparent reporting of } \\
\text { information on bank trusts }\end{array}$ & $\begin{array}{l}\text { Implemented: According to Art } 68 \text { of the Bank Law, } \\
\text { banks must report to the SSF. However, these are no } \\
\text { longer a major issue. }\end{array}$ \\
\hline
\end{tabular}




\begin{tabular}{|c|c|}
\hline 2004 Recommendation & Current Status \\
\hline $\begin{array}{l}\text { - Prevent regulatory arbitrage through the repo } \\
\text { market }\end{array}$ & $\begin{array}{l}\text { Not implemented: No further action undertaken, but not } \\
\text { a major issue as repo market is very limited. }\end{array}$ \\
\hline \multicolumn{2}{|l|}{ C. Strengthening microfinance } \\
\hline $\begin{array}{l}\text { - Limit public action to providing an appropriate } \\
\text { regulatory framework }\end{array}$ & $\begin{array}{l}\text { Partially Implemented: Ley de Bancos Cooperativos and } \\
\text { Sociedades de Ahorro y Crédito enacted. Some direct } \\
\text { public action in microfinance remains via government } \\
\text { funds (e.g., FOSOFAMILIA). }\end{array}$ \\
\hline $\begin{array}{l}\text { - Adjust capital requirements to systemic risk } \\
\text { factors }\end{array}$ & $\begin{array}{l}\text { Partially Implemented: the above law establishes } \\
\text { minimum capital requirements for different categories of } \\
\text { microfinance institutions. No requirements exist for } \\
\text { unregulated microfinance institutions. }\end{array}$ \\
\hline $\begin{array}{l}\text { - Regulate comprehensively the purchasing and } \\
\text { financing of loan portfolios }\end{array}$ & $\begin{array}{l}\text { Partially Implemented: } \text { Regulations exist that have } \\
\text { facilitated bond issuances by microfinance providers. }\end{array}$ \\
\hline $\begin{array}{l}\text { - Incorporate an explicit insurance component in } \\
\text { BMI second-floor lending }\end{array}$ & $\begin{array}{l}\text { Not Implemented: As the domestic presence of } \\
\text { international banks increased, BMI lost its role as a } \\
\text { second floor liquidity provider as BMI's cost of funds is } \\
\text { higher than the foreign-owned banks. }\end{array}$ \\
\hline \multicolumn{2}{|c|}{ D. Enhancing the insolvency and creditor rights system } \\
\hline $\begin{array}{l}-\quad \text { Draft and enact unified insolvency law and } \\
\text { liquidation proceedings }\end{array}$ & $\begin{array}{l}\text { Partially Implemented: The law was drafted but it was } \\
\text { not enacted. The discussions on the Insolvency Law were } \\
\text { on hold for some time, but re-started under the current } \\
\text { government. However, there is no concrete time frame } \\
\text { for voting on the law. }\end{array}$ \\
\hline $\begin{array}{l}\text { - Reform procedural legislation for efficient } \\
\text { enforcement proceedings }\end{array}$ & $\begin{array}{l}\text { Not Implemented: There is an on-going debate on laws } \\
\text { and reforms that would contribute to efficient } \\
\text { enforcement proceedings (Ley de Garantías, Ley de } \\
\text { Insolvencia). }\end{array}$ \\
\hline - $\quad$ Complete reform of real estate registry system & $\begin{array}{l}\text { Partially Implemented: The Central Nacional de } \\
\text { Registros (CNR) (with support from the WB) completed } \\
\text { the first reform phase, creating a centralized electronic } \\
\text { registration of all properties in } 6 \text { departments. The CNR } \\
\text { is currently starting to implement the second phase of the } \\
\text { reform. This phase is expected to complete the } \\
\text { registration of all properties in the remaining } 8 \\
\text { departments. }\end{array}$ \\
\hline $\begin{array}{l}\text { - Create and implement a single registry for } \\
\text { securities on movable assets }\end{array}$ & $\begin{array}{l}\text { Implemented: The CNR manages collateral registries for } \\
\text { both movable and immovable assets. }\end{array}$ \\
\hline $\begin{array}{l}\text { - } \quad \text { Build institutional capacity and modernize } \\
\text { commercial courts }\end{array}$ & $\begin{array}{l}\text { Not Implemented: Despite the significant administrative } \\
\text { reforms on the justice system, commercial courts still } \\
\text { face the same constrains. Lack of adequate institutional } \\
\text { capacity prevents efficiency gains, particularly in an } \\
\text { environment of increasing demand for commercial courts } \\
\text { (disputes increased from } 60 \text { per months in } 2009 \text { to more } \\
\text { than } 110 \text { per month in } 2010 \text { ). }\end{array}$ \\
\hline $\begin{array}{l}\text { - Create an enabling environment for voluntary } \\
\text { out-of-court workouts }\end{array}$ & $\begin{array}{l}\text { Partially Implemented: A Consejo de Mediación y } \\
\text { Arbitraje was created in Cámara de Comercio e Industria. } \\
\text { However, the number of out-of court workouts is still } \\
\text { small. }\end{array}$ \\
\hline
\end{tabular}

\section{Additional Recommendations}

E. Improving the supervisory framework

- $\quad$ Assess expertise, background, training, and $\quad$ Partially Implemented: Periodic compensation and skills assessments are done. 


\begin{tabular}{|c|c|}
\hline 2004 Recommendation & Current Status \\
\hline \multicolumn{2}{|l|}{ compensation of SSF staff } \\
\hline $\begin{array}{l}\text { - } \quad \text { Carry out an in-depth review of current and } \\
\text { expected operational work load of SSF }\end{array}$ & $\begin{array}{l}\text { Partially Implemented: The SSF makes use of annual } \\
\text { inspection plans }\end{array}$ \\
\hline $\begin{array}{l}\text { - Train examiners to assess credit, fiduciary, and } \\
\text { operational risks }\end{array}$ & Implemented: SSF staff is sent to specialized training \\
\hline $\begin{array}{l}\text { - Adopt procedures to review and evaluate the } \\
\text { business of financial conglomerates }\end{array}$ & $\begin{array}{l}\text { Not Implemented: No new regulation, nor special } \\
\text { procedures established for financial conglomerates }\end{array}$ \\
\hline $\begin{array}{l}\text { - Combine qualitative with quantitative analysis to } \\
\text { better assess risk and motivate prompt corrective } \\
\text { action }\end{array}$ & $\begin{array}{l}\text { Partially Implemented: Greater use of qualitative } \\
\text { judgment is required. }\end{array}$ \\
\hline $\begin{array}{l}\text { - Organize dedicated teams of examiners for } \\
\text { conglomerates }\end{array}$ & Not Implemented. \\
\hline \multicolumn{2}{|c|}{ F. Strengthening risk management by financial institutions } \\
\hline $\begin{array}{l}\text { Regulate non-dollar foreign exchange risk and } \\
\text { interest rate risk (BCP 12) }\end{array}$ & $\begin{array}{l}\text { Not Implemented: no new regulation issued on foreign } \\
\text { exchange and interest rate risks }\end{array}$ \\
\hline $\begin{array}{l}\text { - Provide guidance on systems to identify, } \\
\text { measure, monitor, and control risks (BCP 13) }\end{array}$ & $\begin{array}{l}\text { Not Implemented: no new regulation issued specifying } \\
\text { corporate governance }\end{array}$ \\
\hline $\begin{array}{l}\text { - Fully implement Article } 63 \text { of the banking law on } \\
\text { governance, risk management and controls, and } \\
\text { provide best practice standards }\end{array}$ & Not Implemented: no new regulation issued \\
\hline \multicolumn{2}{|c|}{ G. Developing early warning systems and conducting stress tests } \\
\hline $\begin{array}{l}\text { - Conduct regular stress tests on bank asset quality } \\
\text { and liquidity }\end{array}$ & $\begin{array}{l}\text { Partially Implemented. The safety net providers (BCR, } \\
\text { SSF and IGD) have each made laudable progress in } \\
\text { analyzing banking risks, and an interagency risk } \\
\text { committee has been established. Even so, the current } \\
\text { stress test methodology is not fully in line with best } \\
\text { practices, and activities are not well coordinated across } \\
\text { the safety net providers. The newly-formed committee } \\
\text { should therefore focus on unifying and upgrading the } \\
\text { approach with a view to conducting stress tests regularly. }\end{array}$ \\
\hline $\begin{array}{l}\text { - Collect and analyze data on size and } \\
\text { concentration of deposits and on maturity ladders of } \\
\text { assets and liabilities }\end{array}$ & $\begin{array}{l}\text { Partially Implemented: Data on size, concentration and } \\
\text { maturity of deposits are still not available. }\end{array}$ \\
\hline \multicolumn{2}{|c|}{ H. Developing the money market and strengthening the payments system $1 /$} \\
\hline - Introduce an RTGS system & $\begin{array}{l}\text { Implemented: BCR started operating an RTGS system in } \\
\text { February } 2010\end{array}$ \\
\hline - $\quad$ Strengthen unwinding procedures & $\begin{array}{l}\text { N/A: The implementation of the RTGS system avoids the } \\
\text { need for unwinding procedures }\end{array}$ \\
\hline $\begin{array}{l}\text { - Implement full dematerialization of securities in } \\
\text { CEDEVAL }\end{array}$ & $\begin{array}{l}\text { Partially Implemented: Most securities have been } \\
\text { dematerialized, but the majority of the securities of bank } \\
\text { conglomerates are still in physical form. }\end{array}$ \\
\hline - $\quad$ Establish a "National Payments Council" & Not Implemented: Not established. \\
\hline \multicolumn{2}{|l|}{ I. Insurance supervision and state-owned banks 1/ } \\
\hline $\begin{array}{l}\text { - Strengthen supervision of insurance companies } \\
\text { and reduce duplication of efforts }\end{array}$ & $\begin{array}{l}\text { Partially Implemented: SSF launched a new } \\
\text { qualification system (CARAMEL) to assess solvency, } \\
\text { assets and liabilities, reinsurance, profitability and admin } \\
\text { costs of insurance companies. On-site visits with risk } \\
\text { personnel and coordinated visits for conglomerates are } \\
\text { under way. The SSF is still developing risk-based } \\
\text { mechanisms to move beyond accounting rules. }\end{array}$ \\
\hline - $\quad$ Restructure and privatize state-owned banks & $\begin{array}{l}\text { Partially Implemented: none of the state-owned banks } \\
\text { have been privatized or divested. On the other hand, they } \\
\text { have been restructured and cost-to-income ratios have } \\
\text { declined. }\end{array}$ \\
\hline
\end{tabular}


Appendix II. El Salvador: Risk Assessment Matrix

\begin{tabular}{|c|c|c|}
\hline \multirow[b]{2}{*}{$\begin{array}{l}\text { Nature/Source of Main } \\
\text { Threats }\end{array}$} & \multicolumn{2}{|c|}{ Overall Level of Concern } \\
\hline & $\begin{array}{l}\text { Likelihood of Severe Realization } \\
\text { of Threat (in the next } 2 \text { years) }\end{array}$ & $\begin{array}{l}\text { Expected Impact on Financial } \\
\text { Stability if Threat is Realized }\end{array}$ \\
\hline $\begin{array}{l}\text { 1. Absent strong fiscal measures, } \\
\text { public debt levels are highly } \\
\text { sensitive to interest rate and } \\
\text { growth shocks (Art. IV Staff } \\
\text { Report, Box 2). Failure to pass a } \\
\text { fiscal pact could cause concerns } \\
\text { about the sustainability of public } \\
\text { debt and difficulty in rolling over } \\
\text { market debt. }\end{array}$ & $\begin{array}{l}\text { LOW to MEDIUM } \\
\text { - In } 2009 \text {, sovereign spreads } \\
\text { increased by } 100 \text { bps relative to regional } \\
\text { average and the sovereign rating was } \\
\text { downgraded } 1-2 \text { notches below } \\
\text { investment grade due to uncertainty } \\
\text { about government policies. However, El } \\
\text { Salvador was able to successfully place } \\
\text { an } \$ 800 \text { billion Eurobond. } \\
\text { - Two of three international credit } \\
\text { rating agencies have a negative outlook } \\
\text { for the sovereign credit rating (BB/Ba } 1 \text { ) } \\
\text { given the low growth prospects and } \\
\text { need for fiscal measures to ensure } \\
\text { sustainable debt levels. } \\
\quad \quad \text { Gross financing needs ( } 7 \text { and } \\
8 \text { percent of GDP in } 2010 \text { and } 2011) \\
\text { include refinancing a } \$ 600 \text { million } \\
\text { Eurobond (2 percent of GDP) in the } \\
\text { second half of } 2011 . \\
\quad \quad \text { However, net financing of } \\
111 / 2 \text { percent of GDP per year is } \\
\text { automatically generated by private } \\
\text { pension funds. In addition, banks hold } \\
\text { excess reserves (about } 1 \text { percent of } \\
\text { GDP). } \\
\text { - Thus, while a default would } \\
\text { appear unlikely in the near-term given } \\
\text { the availability of funds, interest rates } \\
\text { and interest rate volatility may increase. }\end{array}$ & $\begin{array}{l}\text { MEDIUM to HIGH } \\
\quad \text { Banks are not vulnerable to direct } \\
\text { interest rate shocks: Stress tests show } \\
\text { most banks are resilient to an interest } \\
\text { rate shock of } 3.0 \text { percentage points } \\
\text { (double the } 99^{\text {th }} \text { percentile change) over } \\
6 \text { months. Interest-rate induced credit } \\
\text { risk is not significant. } \\
\quad \text { Given the net financing needs and } \\
\text { excess liquidity in the system, the } \\
\text { system could absorb increased } \\
\text { government reliance on domestic } \\
\text { funding in case external markets are } \\
\text { unfavorable, without putting much } \\
\text { pressure on interest rates and growth. } \\
\quad \quad \text { However, domestic concerns } \\
\text { about the sustainability of public debt, } \\
\text { could lead to lower investment, credit } \\
\text { and growth, which would increase NPLs } \\
\text { and reduce profitability. The impact } \\
\text { could be higher than in } 2009 \text { given } \\
\text { borrower balance sheets may be } \\
\text { weaker following the recent recession. } \\
\text { - Furthermore, concerns about } \\
\text { unsustainable public debt could lead to } \\
\text { deposit withdrawals and capital flight. } \\
\text { Without SBA funds to provide liquidity to } \\
\text { the system, banks run down liquid } \\
\text { assets and further reduce credit. The } \\
\text { impact on NPLs and profitability could } \\
\text { be more severe and the central bank } \\
\text { may not have sufficient funds to provide } \\
\text { liquidity assistance to all banks, which } \\
\text { could lead to bank(s) failure. }\end{array}$ \\
\hline $\begin{array}{l}\text { 2. A double dip recession in the } \\
\text { United States causes a sharp } \\
\text { decline in Salvadoran economic } \\
\text { activity. }\end{array}$ & $\begin{array}{l}\text { LOW to MEDIUM } \\
\text { - Half of exports are destined to the } \\
\text { United States, while a third go to other } \\
\text { Central American markets, which would } \\
\text { also weaken if there is a U.S. recession. } \\
\text { Workers' remittances ( } 16 \text { percent of } \\
\text { GDP), which help finance domestic } \\
\text { consumption, are closely tied to U.S. } \\
\text { labor market conditions. } \\
\text { - The April WEO forecasts output } \\
\text { among trading partners to grow at near } \\
\text { pre-crisis rates. However, more recent }\end{array}$ & $\begin{array}{l}\text { MEDIUM } \\
\text { - Bank profitability has already } \\
\text { been hit hard by the current recession } \\
\text { (and a couple banks still have negative } \\
\text { profits), although CAR remains } \\
\text { relatively high. } \\
\text { - A second recession and higher } \\
\text { borrowing costs would further reduce } \\
\text { income and weaken the balance sheets } \\
\text { of firms and households, negatively } \\
\text { impacting banks' asset quality and } \\
\text { profitability. }\end{array}$ \\
\hline
\end{tabular}




\begin{tabular}{|c|c|c|}
\hline & $\begin{array}{l}\text { data suggests that U.S. growth may be } \\
\text { less robust. In the absence of medium- } \\
\text { term fiscal measures, concerns about } \\
\text { U.S. debt levels could rise and lead to } \\
\text { higher interest rate premia and further } \\
\text { lower growth. Given the level of } \\
\text { leverage in the U.S., both private and } \\
\text { public balance sheets remain vulnerable } \\
\text { to shocks. } \\
\text { - Public debt levels are highly } \\
\text { sensitive to growth shocks (Art. IV Staff } \\
\text { Report, Box 2). If the SBA is on track, } \\
\text { confidence would be maintained in the } \\
\text { face of such a shock. } \\
\text { - However, if the SBA goes off track } \\
\text { due to this shock, it may trigger a } \\
\text { sovereign credit rating downgrade, } \\
\text { reduced access to external financing, } \\
\text { and higher borrowing costs for the } \\
\text { economy. }\end{array}$ & $\begin{array}{l}\text { - Stress tests show that a sharp } \\
\text { decline in economic activity and } \\
\text { remittances combined with higher } \\
\text { interest rates (extreme scenario) could } \\
\text { lead to three banks falling below } 10 \\
\text { percent CAR (thus subject to } \\
\text { regularization), but only one small bank } \\
\text { would be critically undercapitalized. } \\
\text { - However, a recession may hit } \\
\text { banks' large borrowers harder, as has } \\
\text { been the recent experience (Fig. } 7 \text { ) or } \\
\text { because the sovereign downgrade } \\
\text { creates difficulty in rolling-over external } \\
\text { debt. This would more seriously affect } \\
\text { the banking sector, including some } \\
\text { large banks. } \\
\text { - As long as the SBA remains on } \\
\text { track, there should be enough funds to } \\
\text { maintain confidence (or meet large } \\
\text { wihthdrawals in the event that they do } \\
\text { occur). }\end{array}$ \\
\hline $\begin{array}{l}\text { 3. Uncertainty about government } \\
\text { policies or natural disaster causes } \\
\text { a significant decline in confidence } \\
\text { and deposit withdrawals. }\end{array}$ & $\begin{array}{l}\text { LOW to MEDIUM } \\
\text { - Policies to date, including the 3- } \\
\text { year SBA, have underscored the } \\
\text { authorities' commitment to } \\
\text { macroeconomic stability and the rule of } \\
\text { law. } \\
\text { - However, recent legislative } \\
\text { proposals and executive decrees have } \\
\text { increased concerns about legal security } \\
\text { and the independence of key } \\
\text { institutions. }\end{array}$ & $\begin{array}{l}\text { LOW to MEDIUM } \\
\text { - } \quad \text { Pre-election uncertainty in } 2009 \\
\text { led to some deposit outflows (although } \\
\text { less than } 3 \text { percent in the } 3 \text { weeks } \\
\text { leading up to the election) and } \\
\text { contributed to the recession in EI } \\
\text { Salvador being worse than in the US. } \\
\quad \text { Signs of political fractioning and } \\
\text { populist policies could lead to deposit } \\
\text { outflows that would put pressure on } \\
\text { bank liquidity. } \\
\quad \text { Banks' have high levels of liquidity } \\
\text { (around } 40 \text { percent of deposits) that } \\
\text { could likely meet most outflows (which } \\
\text { historically have been less than } 30 \\
\text { percent of deposits, both in other } \\
\text { periods of political uncertainty in El } \\
\text { Salvador, as well as in other countries } \\
\text { suffering systemic liquidity crisis). } \\
\text { - Nonetheless, deposit outflows } \\
\text { could cause a rise in interest rates and } \\
\text { reduce the flow of credit to the private } \\
\text { sector, leading to an increase NPLs and } \\
\text { decrease in profitability (which may } \\
\text { further reduce CARs). }\end{array}$ \\
\hline $\begin{array}{l}\text { 4. Natural disaster causes a } \\
\text { significant increase in public debt, } \\
\text { reduced growth and a decline in } \\
\text { confidence. }\end{array}$ & $\begin{array}{l}\text { LOW to MEDIUM } \\
\text { - In recent years EI Salvador has } \\
\text { sustained damage from several minor } \\
\text { earthquakes, storms, and droughts. } \\
\text { Historically natural disasters have cost }\end{array}$ & $\begin{array}{l}\text { LOW to MEDIUM } \\
\text { - Systemic liquidity could initially } \\
\text { decline arising from use of deposits for } \\
\text { short-term needs and reduced exports. } \\
\text { However, this is likely to be offset to }\end{array}$ \\
\hline
\end{tabular}




\begin{tabular}{|c|c|c|}
\hline & $\begin{array}{l}\text { the government } 3 \text { percent of GDP on } \\
\text { average; authorities are recommended } \\
\text { to reduce debt by an equivalent amount } \\
\text { in order to ensure there exists and } \\
\text { adequate fiscal buffer (Art. IV Staff } \\
\text { Report, Box 2). } \\
\text { - Larger, macro-relevant events } \\
\text { have occurred with less frequency. The } \\
\text { last major event was a pair of } \\
\text { earthquakes in } 2001 \text { from which } \\
\text { damage was estimated at around } \\
12 \text { percent of GDP (with fiscal costs of } \\
\text { around } 7 \text { percent of GDP). Along with } \\
\text { other shocks (e.g., } 9 / 11 \text { ), growth } \\
\text { stagnated in the early part of the } \\
\text { decade. }\end{array}$ & $\begin{array}{l}\text { some extent by increased transfers and } \\
\text { IFI disaster-related lending. } \\
\text { - The decline in productive capacity } \\
\text { could be offset somewhat by increased } \\
\text { foreign transfers. If growth stagnates, } \\
\text { but does not decline, stress tests show } \\
\text { that only one small bank may fall below } \\
\text { the required } 12 \text { percent CAR. } \\
\text { - However. the use of IFI funding } \\
\text { would increase public debt and could } \\
\text { increase interest rate risk prima and } \\
\text { volatility, as well as concerns about the } \\
\text { sustainability of public debt (see trigger } \\
\text { 3). }\end{array}$ \\
\hline $\begin{array}{l}\text { 5. Failure of a systemically } \\
\text { important bank }\end{array}$ & $\begin{array}{l}\text { LOW } \\
\text { banks would become severely } \\
\text { undercapitalized in the case of large } \\
\text { macroeconomic or sectoral shocks, and } \\
\text { that liquid assets are sufficient to } \\
\text { withstand large deposit outflows. }\end{array}$ & $\begin{array}{l}\text { HIGH } \\
\text { - The direct impact may be low, due } \\
\text { to limited interbank exposure. } \\
\text { - However, deficiencies in the } \\
\text { resolution framework that delay prompt } \\
\text { corrective action may result in higher } \\
\text { resolution costs. } \\
\text { - } \\
\text { the deposit insurance fund lacks } \\
\text { (insurance reserves are only around } 1 \\
\text { percent of total deposits). } \\
\text { - While the BCR is authorized to } \\
\text { lend to the IGD, it is also limited by } \\
\text { relatively low levels of excess reserves } \\
\text { and may have difficulty borrowing funds } \\
\text { to resolve a banking crisis, even with a } \\
\text { government guarantee on its borrowing. } \\
\text { - } \\
\text { running a large deficit and the public } \\
\text { debt level is considered high. Thus an } \\
\text { increase in coverage of deposits or a } \\
\text { blanket guarantee to avoid runs may } \\
\text { not be credible. }\end{array}$ \\
\hline
\end{tabular}




\section{Annex: Observance of Financial Sector Standards and Codes-Summary Assessment of Basel Core Principles for Effective Banking Supervision}

\section{Introduction}

1. This assessment of the Basel Core Principles (BCP) was conducted as part of the FSAP update evaluation of the El Salvador financial system from April 22 - May 10, 2010. The supervisory framework was assessed against the BCP methodology issued in October 2006. The assessment was conducted by Mr. Miquel Dijkman (World Bank) and Socorro Heysen (consultant for the IMF).

\section{Information and methodology used for assessment}

2. The authorities provided the assessment team with key documentation, including a selfassessment of compliance with the 25 Basel Core Principles, the legal and regulatory framework for banking supervision, off-site monitoring reports and various other reporting schedules submitted by the banks. Extensive discussions were held with the supervisory staff of the Superintendencia del Sistema Financiero (SSF). Meetings were also held with representatives from the Banco Central de Reserva (BCR), a number of external auditors, and private bankers. As part of the assessment of home-host relationships, a telephone interview was held with two home supervisors of major Salvadoran banks.

3. The assessment of compliance with each principle is made on a qualitative basis. A fourpart assessment system is used: compliant; largely compliant; materially non-compliant; and non-compliant. The ratings assigned during this assessment are not comparable to the ones assigned in the 2000 FSAP, as the bar to measure the effectiveness of a supervisory framework has been raised in the new methodology. New criteria have also been added while existing ones have been redefined.

\section{Institutional and macroeconomic setting and market structure-overview}

4. The Salvadoran financial sector is dominated by banks. There are currently 9 private banks, 2 state banks, 2 foreign branches, 2 savings and loan associations and 6 cooperative banks for which the SSF is responsible for the licensing, regulation and supervision (hereinafter called 'scheduled banks').

5. Bank ownership has changed substantially in the last few years. All private domestic banks have been bought by international or regional banks (e.g., Citibank Cuscatlán, HSBC Banistmo, Scotia, Bancolombia Agrícola, and BAC). As before, financial groups (i.e., those including a combination of banks, insurance and securities companies), remain an important feature of the financial system, but now have a an increasingly international and regional dimension: at end-2005, the four largest groups (HSBC, Citibank, UNO and Bancolombia) represented 31 percent of the financial company assets in the region.

6. The Salvadoran financial system is comparable with its regional peers in terms of size. Although (foreign-owned) banks still constitute the backbone of the financial sector, the banking sector's share has been falling. As of end-2009, banks' assets amounted to over US\$ 13 billion, equivalent to about 64 percent of total financial assets, compared to US\$ 11 billion or 74 percent in 2004. By contrast, the market share of private pension funds expanded rapidly from US\$ 2.2 
billion to US\$ 5.2 billion (14.7 percent to 25.2 percent of financial assets). Consumption and mortgage credit have increased at the expense of corporate loans. Following a similar pattern as in Guatemala and in Honduras, credit to firms has dropped continuously.

7. The financial system has weathered the global financial crisis reasonably well. Reflecting a flight out of riskier assets and a number of recapitalization rounds, capital adequacy levels slightly increased and currently averages nearly 17 percent. Non-performing loans (NPL) amount to 3.8 percent of total loans, up from about 2 percent before the crisis. Specific provisions currently cover some 110 percent of total NPLs, which are defined as loans more than 90 days overdue. Following the severe deterioration of the real economy, provisioning increased significantly in 2009. This affected profitability, as the return on assets fell from 1.2 percent in 2007 to 0.4 percent in early 2010 .

8. Since the last FSAP, the SSF has embarked upon an ambitious project to move towards risk-based supervision. The SSF was reorganized in 2008 and now features a Dirección de Riesgos with specialists in various risk categories, which allows the supervisory teams to tap the specialized expertise that is available in the Dirección.

9. In response to the changing ownership structures in the Salvadoran banking sector, the SSF has also stepped up efforts to enhance cross-border cooperation, both bilaterally and regionally. The SSF has signed Memoranda of Understanding with all home supervisors. These agreements primarily cover exchange of information in the context of ongoing supervision. In addition, the Comite de Enlace of Central American supervisors (CECAS) has stepped up regional coordination. CECAS has quarterly meetings and monthly teleconferences where supervisors present relevant information, risks and concerns about the banks operating under their jurisdictions.

10. The Salvadoran authorities are also in the process of overhauling the supervisory landscape. A draft Law ${ }^{34}$ is currently discussed in the Asamblea, and agreement is expected in the course of this year. The law aims to separate powers of regulation, supervision and sanctioning. It does so by (i) transferring the right to issue regulation from the Superintendency of Banks (SSF) to the central bank (BCR), (ii) merging the superintendencies of banks, securities firms, and pension funds, thus creating a sole supervisory authority, and (iii) establishing an independent sanctions committee.

11. Notwithstanding the positive developments, there are serious enforcement issues. The SSF's effectiveness as a supervisory agency is affected by a lack of legal protection of supervisors. Litigation can and does occur in practice. The SSF ability to address imprudent behavior by banks is also compromised by gaps in the regulatory framework. Regulation is lacking in such areas as corporate governance, credit risk, liquidity risk, market risk, operational risk, interest rate in the banking book, information technology and investment valuation and derivatives. Although supervisory practices in these areas have improved, the lack of standards puts the SSF at a disadvantage in addressing imprudent behavior by banks. This is aggravated by the limitations of the current remedial action framework, which includes only limited powers for the SSF to take preventive action at an early stage, i.e. before inadequate practices or

\footnotetext{
${ }^{34}$ The Ley de Supervisión y Regulación del Sistema Financiero (Financial System Supervision and Regulation Law)
} 
vulnerabilities lead to undercapitalization. The toolkit does for instance not include powers for the supervisor to limit the distribution of dividends, constrain existing or new operations and acquisitions, or enforce the sale of assets.

12. In pushing forward the transition towards risk-based supervision, the SSF faces human resource constraints. The SSF's supervisory capacity already seems stretched, which is aggravated by the addition of new tasks to the supervisors' responsibilities, in particular with regard to consumer protection. A further upgrading of supervisory capacity, both in quantitative and in qualitative terms, is therefore necessary.

\section{Preconditions for effective bank supervision}

13. The Salvadoran economy is characterized by full dollarization and tight links to the United States. The fully dollarized exchange regime instituted in 2001 replaced a peg to the U.S. dollar that had persisted since 1994. Merchandise exports to the United States amount to 12 percent of GDP, over half of total shipments. Remittances receipts were the highest in Central America at over 17 percent of GDP from 2003-2007 and also come mainly from the United States.

14. Between the 2004 Update and the onset of the global financial crisis in late 2008, economic growth accelerated and macroeconomic fundamentals improved. Helped by buoyant external demand and ample accommodative financing conditions, real GDP grew by an average of 3.6 percent from 2005-2008, compared to 2.1 percent from 2001-2004. Inflation has averaged about 4 percent, anchored by dollarization.

15. The global financial crisis and political uncertainty hit economic activity hard in 2009 . The deteriorating external environment, coupled with uncertainty over macroeconomic policies in the run-up to the 2009 elections sharply reduced trade flows and remittances and raised deposit and lending rates. Private capital flows became negative, as banks and companies paid down foreign liabilities. Domestic credit to the private sector also declined, reflecting both banks' increased risk aversion and lower demand for credit. Private consumption and investment fell sharply, and real GDP declined by 3.5 percent in 2009, after growing by 2.4 percent in 2008 .

16. The public infrastructure in El Salvador is reasonably developed. More than 4000 chartered accountant individuals and firms operate in El Salvador, including representatives of the five large international firms. The Accounting and Auditing Oversight Board (CVCA) is responsible for the oversight of the accounting profession in El Salvador. A transition to IFRS was initiated in 2004, but it is still in progress. All listed companies are required to publish their audited financial statements, according to the IFRS for the non financial firms, and according to the accounting standards defined by their regulators in the case of the financial sector firms. Non listed companies are also subject to various reporting requirements including filing their year end balances with the Commercial Registry. Starting on 2011, all listed companies (with the exception of those in the financial sector) will be require to issue their financial statements using IFRS, while all unlisted companies will use IFRS for small and medium entities. However, the CVCA has limited resources and there is little oversight regarding the compliance with these requirements. 
17. The SSF has set up a so-called Central de Riesgo, which collects credit information of Salvadoran nationals and legal persons provided by supervised institutions only. In addition to the Central, a number of private companies collect credit information for debt provided by unsupervised institution. There is also a functioning central registry that records liens on collateral pledged by debtors. Nonetheless, multiple mortgage loans to one single underlying asset do occur, provided that the total sum of mortgages does not exceed the value of the underlying. Although the primary mortgage provider has to approve the granting of additional mortgage loans, complications in collateral seizure may arise in case the debtor remains current on the primary mortgage but defaults on the other loans. Periodic valuations of real estate assets are mandatory and are conducted by certified specialists.

18. The Salvadoran banking sector has demonstrated considerable dynamism, as is evidenced by major changes in the ownership structure of the local banks and a new bank starting operations. Furthermore, Salvadoran banking is among the most efficient in the region, as is illustrated by the fact that Salvadorian banks present the lowest administrative costs in Central America, suggesting relative efficiency in banking service delivery.

19. The deposit insurance fund (IGD) was created in 1999 and currently covers deposits of up to $\$ 9,000$ at 12 commercial banks and, as of 2010, at 6 cooperative banks and 2 savings and loans associations. ${ }^{35}$ It however lacks resources to undertake its mandate effectively. The IGD is funded by a loan from the BCR (currently $\$ 13$ million) and premiums (equivalent to an annual rate of 0.10 percent of deposits) paid quarterly by member banks. IGD's current reserve fund from BCR and bank contributions (US\$96 million or $1.1 \%$ of total deposits) is enough to finance the resolution of each of the 7 smallest banks and one saving and credit institution individually.

20. There are potentially serious weaknesses in the arrangements for systemic liquidity. The high liquidity ratios for the Salvadoran banks need to be seen against a background of a lacking interbank market, limiting the scope for banks with liquidity surpluses to lend to banks with liquidity shortages. Furthermore, the BCR is as of yet by law prohibited to lend to the banking sector; its lender of last resort function is limited to repurchase of its own or government securities (the latter only if government funds have been deposited expressly for this purpose) or purchase of securities or loans. The BCR is however making preparations to enhance its ability to provide systemic liquidity.

\section{Main Findings}

21. Since the FSAP in 2004 the SSF has taken a number of initiatives to strengthen and upgrade supervision. This includes amongst others the creation of a risk unit with specialized expertise and continued efforts to foster cross border cooperation and coordination. While the efforts have been considerable, and the SSF is lauded for its efforts, the lack of regulation in practically all risk categories is a major impediment for further progress. The lack of standards in those areas, combined with severe shortcomings in legal protection and deficiencies in the remedial action framework for addressing minor transgressions limit the SSF's ability to address imprudent behavior by banks. While supervisory practices have improved considerably, the

\footnotetext{
${ }^{35}$ The IGD does not insure BFA deposits as the BFA is government owned. This exception, established by law, affects the playing field with the rest of financial entities.
} 
transition to risk based supervision is as of yet incomplete. Procedures used by the supervisors are still primarily compliance based and appear to focus on verifying the existence of policies and risk management procedures rather than determining if they appropriate to the size and nature of the bank's activities.

22. The following summarizes the main findings of the detailed assessment of compliance with the BCP.

\section{Objectives, independence, powers, transparency and cooperation (CP1)}

23. The SSF is responsible for the licensing, supervision and regulation of the banking sector and fulfills this through on-site inspections and off-site supervision. The SSF has valuable institutional assets to preserve, including its prestige among the general public, banks, auditors, the financial markets, the trust of the Salvadoran government and the dedication and capacity of its technical staff. It has also undertaken significant efforts to enhance cross-border cooperation, both bilaterally and regionally.

24. In exercising its supervisory tasks, the SSF however suffers from a lack of regulation in key risk areas. Regulation is lacking in such areas as corporate governance, credit risk, liquidity risk, market risk, operational risk, interest rate in the banking book, information technology and investment valuation and derivatives. Although supervisory practices in these areas have improved, the lack of standards puts the SSF at a disadvantage in addressing imprudent behavior by banks.

25. This is aggravated by a lack of legal protection for supervisory staff. Litigation can and does occur. Legal challenges not only distract supervisory resources from where they are needed most, it also impacts the willingness of the SSF to use its corrective powers. Another concern is that the remedial action framework includes only limited powers for the SSF to take preventive action before inadequate practices or vulnerabilities lead to undercapitalization. In particular, the toolkit does not include powers for the supervisor to limit the distribution of dividends, constrain existing or new operations and acquisitions, or enforce the sale of assets. Such measures are necessary to bring about improvements in management and penalize minor transgressions before undertaking more drastic measures, such as regularization.

26. Lastly, the SSF's supervisory resources are stretched, complicating the transition towards risk-based supervision. This is made worse by new tasks added to the supervisors' work load, particularly with regard to consumer protection. Priority should therefore be given to upgrading supervisory capacity, both in quantitative and in qualitative terms.

\section{Licensing and structure (CPs 2-5)}

27. The term 'bank' is defined in the law, as are the permissible activities. Cooperative banks are authorized by the SSF to accept deposits and are automatically regulated and supervised by the SSF as established in the Law on Cooperative Banks. They are also covered by the deposit insurance fund. Cooperatives with assets exceeding US\$ 68.57 million are also subject to mandatory supervision. In practice, a considerable number of cooperatives is factually engaged in attracting deposits (which are instead described as "member contributions") and are below the US\$ 68.57 million threshold. Effective supervision and oversight of this segment is lacking, and 
these cooperatives are not restrained by the definition of permissible activities for cooperative banks of Art. 34 of the Cooperative Banks and Savings and Loan Partnerships Law.

28. Before starting a bank in El Salvador, the SSF must authorize the public call to buy shares. Once the public promotion has been approved, the founders request the SSF's authorization to set up a corporation. The main criteria for the SSF in deciding on the application are the outcomes of the fit and proper test of the shareholders representing more than 1 percent ownership and the assessment of the submitted financial projections and business plans of the new bank. The current Bank Law does however not explicitly allow the SSF to revoke the license if it is based on false information. By lack of corporate governance regulation there is also no clear norm for startup banks to comply with in this area.

29. Regarding transfer of significant ownership, the SSF applies two thresholds of 1 and 10 percent of the shares of the bank. Prior authorization by the SSF is required to exceed these thresholds, which is based on a fit and proper test of the incumbents. The SSF expressed that it did not always manage to identify the ultimate beneficial owners of banks. Reflecting a very high degree of foreign penetration in the financial system, it relies on home supervisors to identify ultimate beneficial owners of the banks with sizable operations in El Salvador. Shareholders who are in the $1-10$ percent bracket and who are no longer considered fit should be prevented from exercising their shareholder rights, as is the case for shareholders owning more than 10 percent. In addition to the annual sworn declarations, shareholders should be required to proactively inform the SSF about any event affecting their suitability.

30. The SSF has the power to review all major acquisitions or investments, against prescribed criteria, including the establishment of cross-border operations. The invested amount may not exceed 50 percent of the equity fund or 10 percent of the loan portfolio, whichever is greater. There is scope for enhancing the legal criteria on the basis of which the SSF assesses acquisition or investment proposals. The SSF assesses the economic feasibility of the proposal, but a risk assessment is not a legal or regulatory requirement, even though it is in practice demanded by the SSF. Also, the criteria should include a check whether the proposed investment does not impede effective supervision.

\section{Prudential regulation and requirements (CPs 6-18)}

31. El Salvador's required level of capital adequacy is 12 percent, higher than the required ratio applied in other Central American countries. The capital adequacy framework is however not fully in line with international standards. The statutory minimum requirement must be seen against a background of a liberal treatment of intangible assets (mostly goodwill), which are not subtracted from capital as required under Basel I. Risk weights currently provide little differentiation for the risk profile of asset base.

32. A tightening of the asset classification and provisioning rules has contributed to an improvement in the management of problem assets. Provisioning levels are now broadly in line with international practices, and the SSF monitors banks' delinquent loan portfolio intensively. The SSF currently lacks the authority to oblige banks to raise provisioning levels over and above the levels that are required according to regulation. Although not required to meet the Core Principle, a number of additional suggestions for further strengthening can be made. Banks are currently required to downgrade corporate loans on the basis of past-due days, with an obligation 
to further downgrades if the repayment capacity of the debtor so warrants. This obligation only applies to corporate debtors, i.e. not to consumer or mortgage loans. Also, when debtors with multiple loans with various banks default on one loan, but stay current on others, the nonaffected loans are not automatically downgraded at all banks. Lastly, the practice of granting several mortgages on the basis of one underlying asset warrants monitoring.

33. There are important gaps in the existing regulatory framework. A considerable amount of regulation is under development, but is slow to be released. Regulation is lacking in such areas as corporate governance, credit risk, liquidity risk, market risk, operational risk, interest rate in the banking book, information technology and investment valuation and derivatives. Supervisory practices in these areas have improved, while the arrival of reputable foreign banks has raised risk management standards. Still, the lack of standards raises compliance issues as the SSF cannot coerce banks to comply with its requirements. There is therefore an urgent need for the SSF to issue standards on key risk categories. The need for doing so is most urgent for credit risk, liquidity risk and corporate governance. Considering that the legal framework is rather vague, a key issue that needs to be addressed in these regulations is to spell out the responsibilities of banks' directors regarding the oversight of management and the internal controls system to ensure that these are adequate relative to the risks and complexity of their operations. It is vital that the upcoming overhaul of the supervisory process, which amongst others entails a transfer of the authority to issue regulation to the BCR, does not delay the issuance of regulation. In this context, the BCR needs to build on the draft regulations that are under development within the SSF.

\section{Methods of Ongoing Supervision (CPs19-21)}

34. The transition towards risk based supervision needs to be enhanced by further upgrading supervisory techniques and practices. The SSF currently uses CAMELS models in order to generate bank-specific risk profiles. After establishing banks' risk profiles, the SSF makes an assessment of the effectiveness of risk mitigants to determine residual risk. There is however a need to bring in more qualitative judgment in this assessment. In addition to checking whether procedures and policies are in place, the SSF faces the challenge of assessing the quality of risk management. The adequacy of risk management needs to be evaluated, considering the bank's characteristics, such as size, complexity and risk appetite.

35. In doing so, the SSF faces human capacity constraints, due to organizational issues and a lack of resources. Offsite responsibilities are currently split over two divisions (Risks and Analysis), and the role and responsibilities of offsite supervision are not well-specified. In addition, individual supervisory staff is often given a number of different roles, which is most problematic in the Risk Division. The unit leaders of this Division are not only responsible for a specific risk for all banks but are also the designated "relationship managers" for a financial conglomerate. The Supervisory Department is resource-constrained, as the increased consumer protection responsibilities entrusted to the SSF have been assigned to this department, diverting supervisory resources away from prudential supervision.

36. A further upgrade of supervisory practices therefore requires capacity building and reorganization of duties. The SSF's supervisory capacity already seems stretched. The mission therefore recommends that the SSF give priority to further upgrading supervisory capacity, both in quantitative and in qualitative terms. 


\section{Accounting and Disclosure (CP 22)}

37. The SSF receives a fairly comprehensive set of information on banks and banking groups, with the exception on relevant data on market and interest rate risks. The accounting manual, which is the basis for the reports submitted to the SSF and the audited financials published by banks, is prudent but outdated and does not conform to international standards. The norm differs from international accounting standards in the calculation of loan loss provisions, valuation of investments, deferred taxes and the extent to which risks and other material issues are revealed.

\section{Corrective and Remedial Powers of Supervisors (CP 23)}

38. The remedial action framework includes only limited powers for the SSF to take preventive action at an early stage, before inadequate practices or vulnerabilities lead to undercapitalization. In particular, the toolkit does not include powers for the supervisor to limit the distribution of dividends, constrain existing or new operations and acquisitions, or enforce the sale of assets. Such measures are necessary to bring about improvements in management and penalize minor transgressions before needing to take more drastic measures, such as regularization.

39. This is aggravated by a lack of legal protection for supervisory staff, as litigation can and does occur. Such legal challenges not only distract supervisory resources from where they are needed most, it also impacts the willingness of the SSF to use its corrective powers. The SSF has not issued regulation on sanctions to clearly define the severity of the violations and the corresponding scale of sanctions and make the sanctioning process more transparent for supervised entities and individuals.

\section{Consolidated and Cross-Border Banking (CPs 24-25)}

40. The SSF has stepped up its efforts to enhance cross-border cooperation, both bilaterally and regionally. In response to the changing ownership structures in the Salvadoran banking sector, it has signed Memoranda of Understanding with all home supervisors. These agreements primarily cover exchange of information in the context of ongoing supervision. In addition, the Comité de Enlace of Central American supervisors (CECAS) has stepped up regional coordination. CECAS has quarterly meetings and monthly teleconferences where supervisors present relevant information, risks and concerns about the banks operating under their jurisdictions. Some progress has also been made in the coordination with local supervisors of entities belonging to the conglomerates, to gather information and conduct simultaneous onsite exams, but additional efforts are needed to have a comprehensive framework to assess the risks that non-banking local activities conducted by a bank or banking group may pose to the bank or banking group. 


\section{Recommended action plan and authorities' response}

41. In the immediate term, the SSF can take advantage of the window of opportunity in the revision of the SSF Law to consider necessary amendments, not included in current drafts.

- Legal protection for bank supervisors

- Wider supervisory powers before the regularization stage (i.e. restrict the distribution of dividends and acquisitions or activities)

- Broaden the requirement that the Board reports on aspects that could affect the stability of the bank to include also other material aspects and events that could affect the bank, short of threatening insolvency or illiquidity.

42. In the short term, it is recommended that the SSF expedite its regulatory process to issue important drafts necessary to enable enforcement of the necessary supervisory actions.

43. Table 1below contains the specific recommendations to bring the supervisory framework up to international standards. 


\section{Annex Table 1. Recommended Action Plan to Improve Compliance with the Basel Core Principles}

\begin{tabular}{|c|c|}
\hline Reference Principle & Recommended Action \\
\hline CP 1.1 Responsibilities and objectives & $\begin{array}{l}\text { Expedite issuance of regulations on the basis of existing } \\
\text { drafts. }\end{array}$ \\
\hline CP 1.2 Independence & $\begin{array}{l}\text { The Council should focus on its oversight role and on key } \\
\text { strategic decisions, rather than being involved in day-to-day } \\
\text { administrative and operational matters. } \\
\text { The grounds for dismissal of the Superintendent should be } \\
\text { described specifically in the law, while the appointment } \\
\text { process should be decoupled from the presidential cycle. The } \\
\text { former would be accomplished by the passage of the bill on } \\
\text { Financial System Regulation and Supervision. } \\
\text { Additional human resources are needed to conduct current } \\
\text { supervisory tasks more thoroughly, especially in view of } \\
\text { additional consumer protection tasks. These tasks would be } \\
\text { best delegated to a separate unit. }\end{array}$ \\
\hline CP 1.4 Legal powers & $\begin{array}{l}\text { Further refine the remedial action framework to enhance the } \\
\text { SSF's powers to act at an early (preventive) stage. }\end{array}$ \\
\hline \begin{tabular}{|l|} 
CP 1.5 Legal protection \\
\end{tabular} & $\begin{array}{l}\text { As a matter of priority, the SSF's staff should be provided } \\
\text { with legal protection for actions undertaken in good faith. The } \\
\text { upcoming overhaul of the financial system supervisory and } \\
\text { regulatory framework is a window of opportunity to address } \\
\text { this urgent issue. }\end{array}$ \\
\hline CP 1.6 Cooperation & $\begin{array}{l}\text { Consider broadening the current cooperation arrangements to } \\
\text { include financial crisis management issues. }\end{array}$ \\
\hline CP 2 Permissible Activities & $\begin{array}{l}\text { Strengthen oversight of the cooperative banking segment and } \\
\text { enhance transparency as to which cooperative banks are } \\
\text { regulated and covered by deposit insurance. A legal } \\
\text { amendment should be passed to require that the Federations } \\
\text { collect information on their member cooperatives and are } \\
\text { obliged to submit it to the SSF. Reduce the legal threshold for } \\
\text { this below the C\$600 million to a more prudent level. }\end{array}$ \\
\hline CP 3 Licensing criteria & $\begin{array}{l}\text { The law should explicitly allow the SSF to revoke a license if } \\
\text { based on false information. } \\
\text { Issue a corporate governance regulation, which will establish } \\
\text { a clear norm with which start up banks should comply. }\end{array}$ \\
\hline CP 4 Transfer of significant ownership & $\begin{array}{l}\text { Shareholders who are in the } 1-10 \text { percent bracket and who } \\
\text { are no longer considered fit should also have their shareholder } \\
\text { rights frozen. In addition to the annual sworn declarations, } \\
\text { shareholders should be required to proactively inform the SSF } \\
\text { of any event arising in the course of the year affecting their } \\
\text { suitability. The SSF should be allowed to annul unauthorized } \\
\text { transfers of ownerships. }\end{array}$ \\
\hline CP 5 Major Acquisitions & $\begin{array}{l}\text { Legal criteria should be extended to include a forward- } \\
\text { looking risk analysis. The criteria should also include a check } \\
\text { whether the proposed investment does not impede } \\
\text { supervision. }\end{array}$ \\
\hline
\end{tabular}




\begin{tabular}{|c|c|}
\hline Reference Principle & Recommended Action \\
\hline CP 6 Capital Adequacy & $\begin{array}{l}\text { The list of deductibles should be broadened to include } \\
\text { intangible assets (including goodwill). The SSF should also be } \\
\text { granted additional discretion in imposing capital add-ons, as } \\
\text { well as discretion with regard to the size of the add-ons. The } \\
\text { latter requires legal changes. }\end{array}$ \\
\hline CP 7 Risk Management Process & $\begin{array}{l}\text { As a matter of priority, issue the appropriate regulation. } \\
\text { Currently, the SSF cannot enforce compliance because a } \\
\text { standard is lacking. }\end{array}$ \\
\hline CP 8 Credit Risk & $\begin{array}{l}\text { As a matter of priority, issue regulation which specifies the } \\
\text { standard, and enhance the supervision of risks, rather than } \\
\text { procedures and policies. The practice of multiple mortgages } \\
\text { on one underlying asset requires monitoring. }\end{array}$ \\
\hline CP 9 Problem assets, provisions and reserves & $\begin{array}{l}\text { The SSF should be given authority to oblige banks to raise } \\
\text { provisions over and above the levels that are required } \\
\text { according to regulation. } \\
\text { Although not required for compliance with the core principle, } \\
\text { a number of additional enhancements for further } \\
\text { strengthening supervision in this area could be considered. } \\
\text { First, the mandatory periodic reassessment of the debtors' } \\
\text { repayment capacity that currently only applies to corporate } \\
\text { sector credit could be extended to consumer and mortgage } \\
\text { sector credit. This would require changes to existing } \\
\text { regulation. In case a debtor with multiple debts to various } \\
\text { banks is delinquent on one loan, all other loans (including the } \\
\text { ones to non-affected banks) should also receive a similar } \\
\text { classification and provisioning treatment as the delinquent } \\
\text { one. }\end{array}$ \\
\hline CP 10 Large Exposure Limits & $\begin{array}{l}\text { The Bank Law grants the SSF the authority to aggregate any } \\
\text { individual exposure for which credit risk is likely to be linked, } \\
\text { but this authority is not put to use in practice. The SSF should } \\
\text { establish aggregate limits for individual large exposures and } \\
\text { for which credit risks are linked. The SSF should take and a } \\
\text { more proactive role in supervising risk concentrations. }\end{array}$ \\
\hline CP 11 Exposures to related parties & $\begin{array}{l}\text { Establish enhanced monitoring requirements for the Boards of } \\
\text { banks regarding delinquent loans to related parties. } \\
\text { Laws and regulation should be made more specific regarding } \\
\text { conflict of interest in granting new loans. Currently for loans } \\
\text { to parties related to senior management or board members or } \\
\text { any of their direct family members prior Board authorization, } \\
\text { must excluding the interested Board member, is necessary. } \\
\text { This requirement should be extended to other categories of } \\
\text { related parties, including by ownership. }\end{array}$ \\
\hline CP 13 Market risks & Issue a regulation on market risks. \\
\hline CP 14 Liquidity risk & $\begin{array}{l}\text { Issue a regulation on liquidity risks, including requirements to } \\
\text { have adequate policies to control concentration and other } \\
\text { liquidity risks, stress testing and contingency plans. }\end{array}$ \\
\hline CP 15 Operational risk & $\begin{array}{l}\text { Issue a regulation on operational risks and a specific norm on } \\
\text { information technology risks. Increase the staff of the } \\
\text { operational risk unit. }\end{array}$ \\
\hline CP 16 Interest rate risk in the banking book & $\begin{array}{l}\text { Issue a regulation on interest rate risks, including specifying } \\
\text { the reports required for the off-site supervisory follow up of } \\
\text { this risk. }\end{array}$ \\
\hline
\end{tabular}




\begin{tabular}{|c|c|}
\hline Reference Principle & Recommended Action \\
\hline CP 17 Internal control and audit & $\begin{array}{l}\text { Issue a corporate governance regulation establishing clear } \\
\text { responsibilities of the Board regarding the adequacy of the } \\
\text { internal control system }\end{array}$ \\
\hline CP 18 Abuse of financial services & $\begin{array}{l}\text { Issue a circular letter requiring banks to have a customer } \\
\text { acceptance policy identifying the relationships that the bank } \\
\text { will not accept, as well as due diligence policies and processes } \\
\text { regarding correspondent banking }\end{array}$ \\
\hline CP 19 Supervisory approach & $\begin{array}{l}\text { Enhance qualitative assessments by the SSF of banks' risk } \\
\text { management practices. The SSF should focus on whether risk } \\
\text { management policies and procedures are adequate given the } \\
\text { risk characteristics of the respective bank, rather than } \\
\text { checking whether policies and procedures are in place. } \\
\text { Broaden the scope of the financial system report of the SSF to } \\
\text { include unsupervised entities (cooperatives). Appoint } \\
\text { dedicated relationship managers responsible for the overall } \\
\text { supervision of each bank. }\end{array}$ \\
\hline CP 20 Supervisory techniques & $\begin{array}{l}\text { Provide specialized training on the supervision of risks and } \\
\text { risk management. }\end{array}$ \\
\hline CP 21 Supervisory reporting & $\begin{array}{l}\text { Include in the draft SSF law a requirement that the Board and } \\
\text { managers report to the SSF all events that are material. }\end{array}$ \\
\hline CP 22 Accounting and disclosure & $\begin{array}{l}\text { Revise the accounting manual to improve disclosure of risks } \\
\text { and introduce rules on derivatives and investments. }\end{array}$ \\
\hline CP 23 Corrective and remedial powers of supervisors & $\begin{array}{l}\text { Include in the draft SSF law a broader range of preventive } \\
\text { measures prior to regularization (i.e., restrictions on the } \\
\text { distribution of dividends, bonuses, new acquisitions, sales of } \\
\text { assets or specific operations). } \\
\text { Issue a regulation on sanctions to clearly typify the severity of } \\
\text { the violations and the corresponding scale of sanctions. }\end{array}$ \\
\hline CP 24 Consolidated supervision & $\begin{array}{l}\text { Establish a comprehensive framework to assess the risks that } \\
\text { non-banking local activities conducted by a bank or banking } \\
\text { group may pose to the bank or banking group }\end{array}$ \\
\hline
\end{tabular}

\section{Authorities' response to the assessment}

44. The SSF agreed with the assessment. 